4 nordon 



\section{Evaluering av Nordplus}

Bjørn Stensaker, Jorunn Spord Borgen, Kazimierz Musial og Vera Schwach 


\section{Evaluering av Nordplus}

TemaNord 2011:516

(C) Nordisk ministerråd, København 2011

ISBN 978-92-893-2204-1

Trykk: Kailow Express ApS

Opplag: 160

Trykt på miljøvennlig papir som oppfyller kravene i den nordiske miljøsvanemerkeordning. Publikasjonen kan bestilles på www.norden.org/order. Flere publikasjoner på www.norden.org/publikationer

Denne rapporten er gitt ut med finansiell støtte fra Nordisk ministerråd. Innholdet i rapporten avspeiler imidlertid ikke nødvendigvis Nordisk ministerråds synspunkter, holdninger eller anbefalinger.

Printed in Denmark

Nordisk ministerråd

Ved Stranden 18

DK-1061 København K

Telefon (+45) 33960200

Fax (+45) 33960202

\section{Nordisk råd}

Ved Stranden 18

DK-1061 København K

Telefon (+45) 33960400

Fax (+45) 33111870

\section{Det nordiske samarbeidet}

Det nordiske samarbeid er en av verdens mest omfattende regionale samarbeidsformer. Samarbeidet omfatter Danmark, Finland, Island, Norge og Sverige, samt de selvstyrende områdene Færøyene, Grønland og Åland.

Det nordiske samarbeid er både politisk, økonomisk og kulturelt forankret, og er en viktig medspiller i det europeiske og internasjonale samarbeid. Det nordiske fellesskap arbeider for et sterkt Norden i et sterkt Europa.

Det nordiske samarbeid ønsker å styrke nordiske og regionale interesser og verdier i en global omverden. Felles verdier landene imellom er med til å styrke Nordens posisjon som en av verdens mest innovative og konkurransekraftige regioner. 


\section{Innhold}

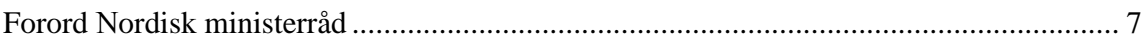

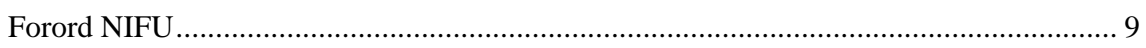

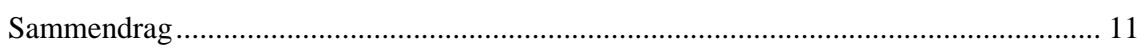

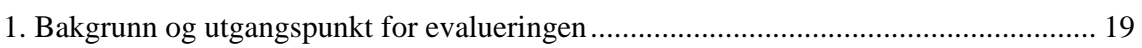

1.1 Sentrale perspektiver og spørsmål i evalueringen av Nordplus ............................ 20

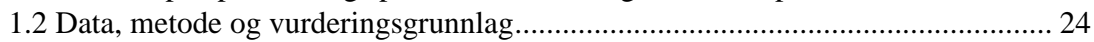

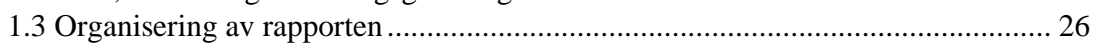

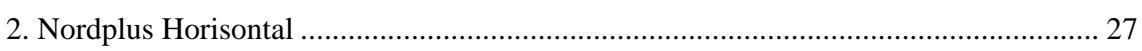

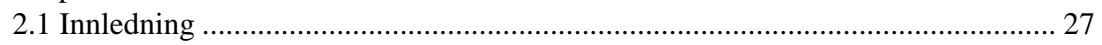

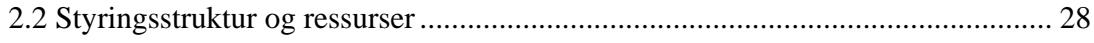

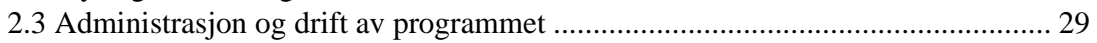

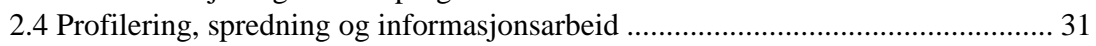

2.5 Måloppnåelse og resultater.................................................................................. 31

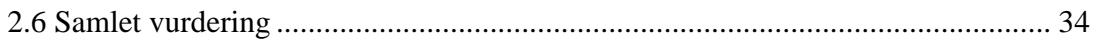

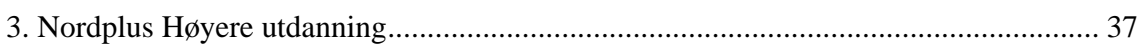

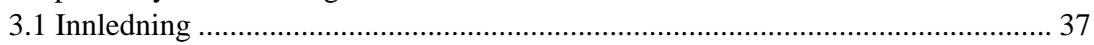

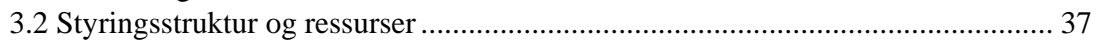

3.3 Administrasjon og drift av programmet ............................................................ 40

3.4 Profilering, spredning og informasjonsarbeid ...................................................... 42

3.5 Måloppnåelse og resultater.............................................................................. 42

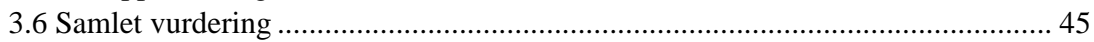

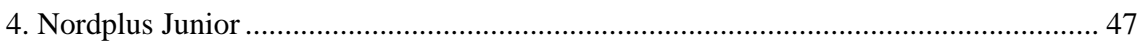

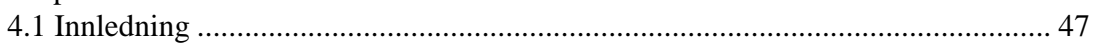

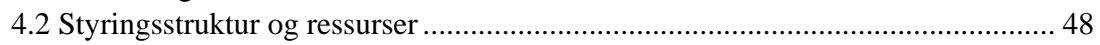

4.3 Administrasjon og drift av programmet ............................................................. 50

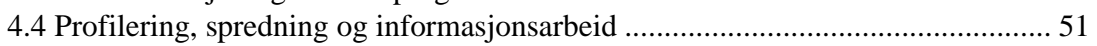

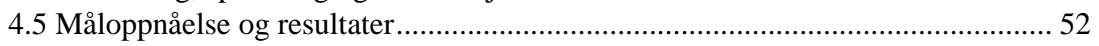

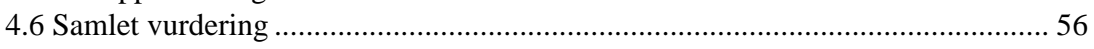

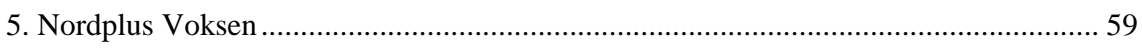

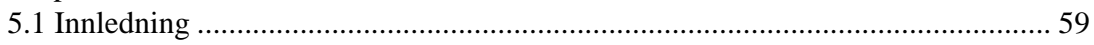

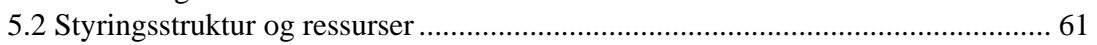

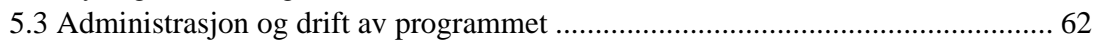

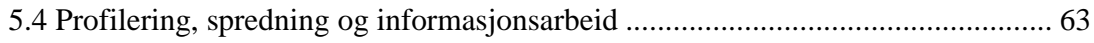

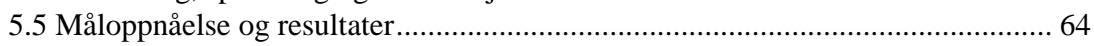

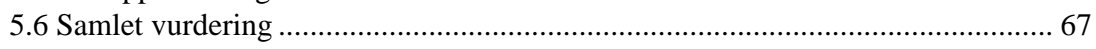

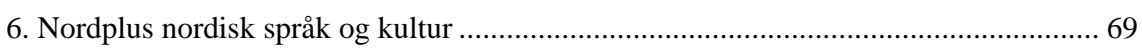

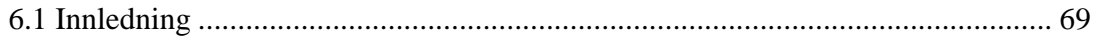

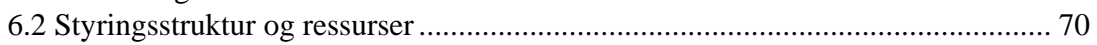

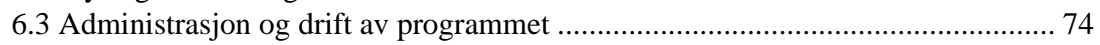

6.4 Profilering, spredning og informasjonsarbeid .................................................... 75

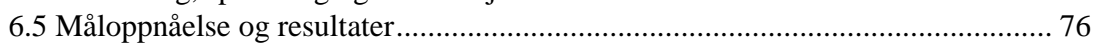

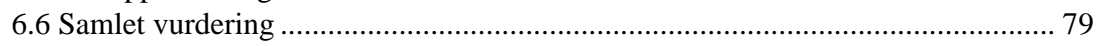




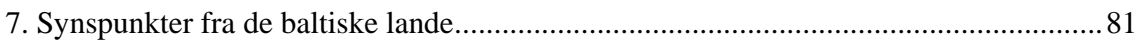

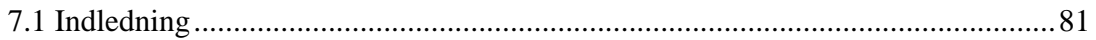

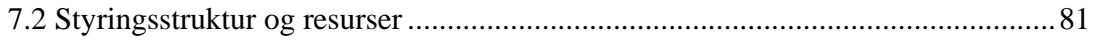

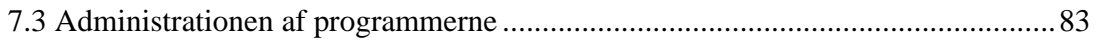

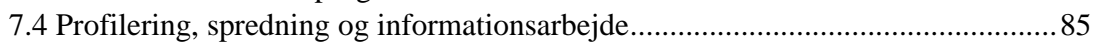

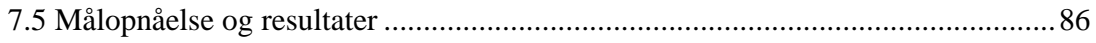

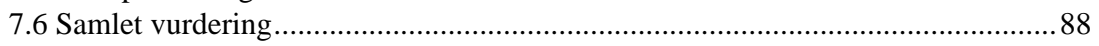

8. Sammenfattende vurdering og hovedkonklusjoner ...................................................... 91

8.1 Funksjonaliteten til, struktur på og styring av programmene ............................... 91

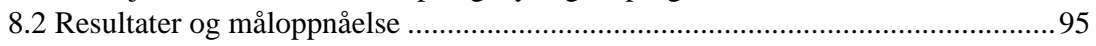

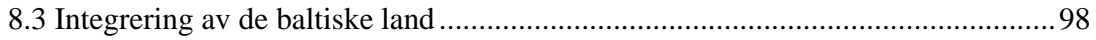

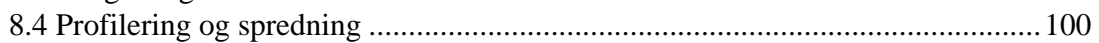

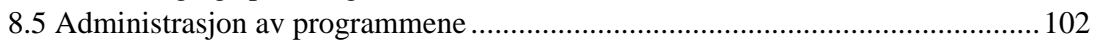

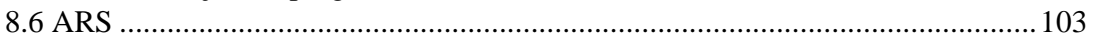

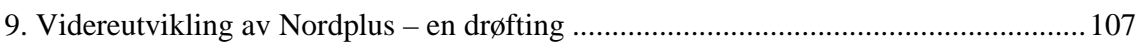

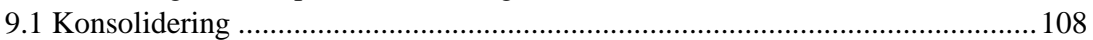

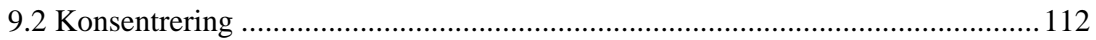

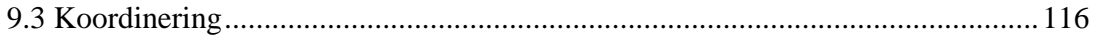

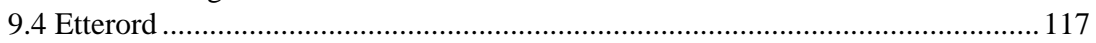

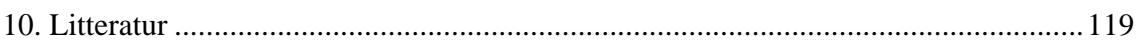

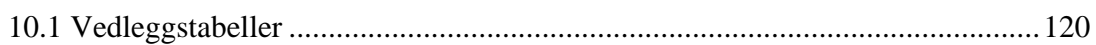




\section{Forord Nordisk ministerråd}

Nordisk ministerråd skal i 2011 beslutte neste generasjon Nordplus.

Nordplus er Nordisk ministerråds største kontinuerlige program og det største nordisk-baltiske samarbeidsområde. Programmene favner bredt over hele livslang læring fra barnehage til universitet, voksenopplæring og språksamarbeid. Programmene har en forhistorie som går over 20 år, og har vokst i både bredde og dybde.

Programmene favner i dag om

- Nordplus Junior - barnehage, førskole, grunnskole og videregående opplæring

- Nordplus Høyere Utdanning - universitet og høyskoler

- Nordplus Voksen - voksenopplæring

- Nordplus Horisontal - samarbeid på tvers av utdanningsnivåer

- Nordplus Nordiske Språk og kultur - språksamarbeid

Fra 2008 deltar de baltiske landene Estland, Latvia og Litauen på like fot i programmet med de fem nordiske landene Island, Norge, Sverige, Danmark og Finland og de tre selvstyrte områdene Færøyene, Grønland og Åland.

Nordplus programmene er nå evaluert av NIFU (Nordisk institutt for studier av innovasjon, forskning og utdanning) på oppdrag fra Nordisk ministerråd. Evalueringen viser at Nordplus er verdifull, at Nordplus gir betydelig merverdi og at det er viktig å videreføre og videreutvikle Nordplus. Det er gledelig at det er mange ideer og meninger om veien videre. Rapporten peker på 3 scenarier som mulige utviklingsveier for Nordplus, og gir konkrete forslag til endringer i programmet.

Ministerrådet vil takke forskerne bak rapporten, og tror at rapporten vil være et godt underlag for den videre utvikling av Nordplus, og de beslutninger som skal tas i 2011. Vi tror samtidig at rapporten kan være god og nyttig lesning for alle som er opptatt av Nordplus og nordisk-baltisk utdanningssamarbeid.

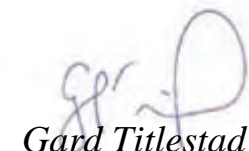

avdelingssjef

Nordisk ministerråd 



\section{Forord NIFU}

Nordisk ministerråd utlyste i 2009 en evaluering av Nordplus rammeprogram og Nordplus Nordiske Språk og Kulturprogram. NIFU STEP (som i desember 2010 skiftet navn til NIFU) fikk i oppdrag å utføre evalueringen som ble gjennomført av forskerne Jorunn Spord Borgen, Bjørn Stensaker og Vera Schwach. NIFU har dessuten trukket inn Kazimierz Musial fra Universitetet i Gdansk underveis i evalueringsprosessen, spesielt i forhold til spørsmålet om baltiske erfaringer med Nordplus.

NIFU vil benytte anledningen til å takke Nordisk ministerråds sekretariat og dagens hovedkoordinator og hovedadministratorer for god assistanse og god kommunikasjon underveis i prosjektet, samt rette en takk til alle involverte i Nordplusamarbeidet som har stilt opp til intervju og som har bidratt med sin kunnskap og erfaringer i prosjektet. Vi håper rapporten kommer til nytte i den fremtidige organiseringen av Nordplus.

Oslo, januar 2011

Sveinung Skule

Direktør
Jannecke Wiers-Jenssen

Forskningsleder 



\section{Sammendrag}

Nordplus har i over 20 år vært det sentrale samarbeidstiltaket innen utdanningsfeltet i Norden, og har helt siden etableringen i 1988 vært organisert i ulike programmer med en tidsbestemt varighet. Nåværende programperiode startet i 2008 og varer til og med 2011. Nordisk ministerråds sekretariat besluttet i 2009 å igangsette en evaluering av Nordisk Rammeprogram og Nordplus Nordiske Språk- og Kulturprogram (NSK). Etter en utlysning ble oppdraget gitt til NIFU. Denne rapporten er den skriftlige rapporteringen fra denne evalueringen.

Nordisk Rammeprogram omfatter fire delprogram

- Nordplus Junior

- Nordplus Horisontal

- Nordplus Høyere utdanning

- Nordplus Voksen.

I det nye Nordplusprogrammet som ble iverksatt fra 2008 deltok for også første gang de baltiske landene, Estland, Latvia og Litauen i det felles Nordplus Rammeprogram. NSK ble besluttet videreført, men som et eget program uten baltisk deltakelse.

De overordnede målsettingene for Nordplus er mangfoldige og inkluderer det å fremme nordisk språk og kultur og gjensidig nordisk-baltisk språklig og kulturell forståelse, bidra til utviklingen av kvalitet og innovasjon i utdanningssystemene, og styrke og utvikle det nordiske utdanningssamarbeidet og bidra til å skape et nordisk-baltisk utdanningsområde.

Evalueringen hadde på denne bakgrunn følgende mandat:

- Hvordan har programmene fungert i programperioden, herunder blant annet programstrukturen og programkomiteene?

- Hvilke resultater er oppnådd sett i forhold til de overordnede målsettingene med innføring av de nye programmene?

- Hvordan har integreringen av de baltiske landene lykkes?

- Hvordan er profilering, spredning og oppfølging av erfaringer og resultater fra programmene gjennomført?

- Hvordan har administrasjonen av programmene fungert, herunder blant annet det elektroniske søknads- og rapporteringssystemet (ARS)?

Sett i et lengre tidsperspektiv har de politiske ambisjonene med Nordplus endret seg relativt mye, og i dag vil en evaluering av Nordplus ikke bare handle om hvorvidt de målsettinger som i sin tid ble spesifisert for pro- 
grammet er oppnådd, men også om Nordplus er et tiltak som er fremtidsrettet og bærekraftig i forhold til dagens politiske kontekst - ikke minst det globaliseringsinitiativ som de nordiske statsministre tok initiativ til i 2007.

Evalueringen har vurdert Nordplus programmene både individuelt og samlet, og de sentrale konklusjonene kan oppsummeres som følger:

\section{Nordplus Horisontal}

Nordplus Horisontal er det yngste programmet i Nordplus familien, og har sin opprinnelse i et ønske om å videreutvikle aktivitetene i Nordplus utover det fokus på mobilitet som tradisjonelt har kjennetegnet programmene. Selv om Horisontal har hatt en del innkjøringsproblemer knyttet til «hva programmet skal være» - opplever både brukere og de som administrerer programmet at programmet i dag er fungerer godt. Horisontal kan sies å ha oppfylt en av de sentrale målsettingene i og med at aktivitetene og prosjektene som er igangsatt er kjennetegnet av en høy grad av nytenkning.

Horisontal representerer på mange måter en nytenkning innen Nordplussamarbeidet, der prosjektene er noe større og deltakerne flere enn i andre programmer. Hvorvidt programmet faktisk har fått en tydelig profil synes likevel å være noe uavklart siden typer brukere har skiftet noe siden oppstarten. Generelt synes ressursrammene for Horisontal å være relativt gode, og det synes i liten grad å være behov for å styrke ressursene. Samarbeidet mellom hoved- og medadministratorene synes også å være velfungerende, og brukerne opplever at programmet driftes på en god måte med god brukerstøtte.

\section{Nordplus Høyere utdanning}

Nordplus Høyere utdanning er det største og mest etablerte programmet i Nordplusfamilien. Hovedinntrykket er at programmet i store trekk er velfungerende. Programmet driftes effektivt, og styringen og administrasjonen av programmet synes å skje profesjonelt og med lave terskler overfor brukerne. Programperioden sett under ett er imidlertid den administrative resultatformidling og analysene av programmet noe mangelfulle, men dette har stor sammenheng med innføringen av ARS i starten av programperioden.

Samtidig er det også mulig å argumentere for at Nordplus Høyere utdanning etter hvert har blitt et så etablert form for samarbeid for en del av nettverkene at støtten fra Nordplus mer tenkes på som «drift» enn som insentiver for å skape merverdi. At antall søknader og at søknadsbeløpet er så høyt som det er, kan tyde på at mange av brukerne søker av «gammel vane» og ut fra tradisjon. Mange av søkerne får også innvilget sin støtte, og det kan stilles spørsmål ved om kvalitet alltid er det viktigste utvelgelseskriteriet når det gjelder søknadsstøtte - spesielt i forhold til mobilitet. Det synes å være rom for mer nytenkning omkring hva dette programmet skal være i årene som kommer. 


\section{Nordplus Junior}

Nordplus Junior synes å være et relevant og interessant program for målgruppen, og brukerne er godt fornøyd. Samtidig er det ulike oppfatninger blant aktørene på de ulike nivåene innenfor Nordplus Junior om hvordan programmet fungerer i dag, og hva som er utfordringer framover. Relativt mange brukere gir uttrykk for at programmet er ressurskrevende, spesielt i forhold til egenandelkravene knyttet til deltakelse. Samtidig synes slike synspunkter til en viss grad å ha sitt opphav i en mangelfull forståelse av hvilken fleksibilitet som er knyttet til disse kravene.

Den lave aktiviteten blant barnehager i Nordplus Junior taler for at denne delen av programmet har liten relevans og bør tas ut. Selv om Nordplus Junior i inneværende programperiode har hatt som formål å støtte utviklingen av kvalitet og fornyelse av grunnopplæringen, spesielt i forhold til utviklingsprosjekt og tematiske nettverk, er hovedaktiviteten likevel mobilitet. Ut fra rammevilkårene i sektoren synes dette å være tydelige signaler om hva som oppfattes som faglig relevant og praktisk mulig.

\section{Nordplus Voksen}

Nordplus Voksen er et sammensatt program med et mangfoldig preg. Utdanning er nøkkelbegrep, og programmet skal stimulere og utvikle voksnes læring, både formell, ikke-formell og uformell læring. Mange typer aktører er aktuelle søkere for å delta i Nordplus Voksen, samtidig har programmet få søkere innenfor uformell læring, og en stor del av aktørene som får midler er større formelle organisasjoner og institusjoner. Selv om egenandelskravet er redusert i Voksen sammenlignet med i de øvrige programmene, er dette likevel et kritisk punkt for deler av målgruppen, mens andre har ressurser til å dekke egenandelen.

Det synes å være ulike tolkninger av regelverket for programmet, og det hevdes å være strenge krav til søkerne innenfor Voksen. Det er ulike synspunkter i programmet på hvorvidt man i programmet fremover skal arbeide for å styrke bredden og mangfoldet, eller at spennvidden i Nordplus Voksen er blitt for stor. Motsetningen mellom å spre kunnskap på institusjonelt nivå, og å gjøre individuelle erfaringer bør diskuteres nærmere i programmet.

\section{Nordplus Språk og Kultur (NSK)}

Nåværende språk- og kulturprogram er en konkretisering av sentrale politiske ideer om nordisk samarbeid; der mye av nytten kan sies å være av immateriell karakter, men ikke mindre vesentlig av den grunn. For arbeidet med de nordiske språkene betyr oppmerksomheten og den finansielle støtten fra programmet mye. I det store og hele fungerer programmet meget bra, ikke minst administrativt. Ressursene synes brukt hensiktsmessig og effektivt. Det har imidlertid noen utfordringer: Noen av dem er av organisatorisk art, mens andre bunner i kunnskapsmessig og/eller politisk uavklarte forhold.

Innholdsmessig er programmets profil i dag noe utydelig. En eventuell ide om en integrasjon mellom språk og kultur er knapt forsøkt gjennomført. 
Kulturdimensjonen har i praksis begrenset selvstendig betydning. Profilen til NSK ville også bli tydeligere om mobilitetsdelen ble flyttet til Nordplus Junior. På den måten ville alle mobilitetstiltak rettet mot samme type målgruppe bli samlet i et og samme program. På den organisatoriske siden nyter programmet godt av at det - i praksis - nærmest er den del av det formelle rammeprogrammet som har god samlet kunnskap om de ulike, relevante målgrupper for programmet, og der det foregår gjensidig utveksling av denne kunnskapen.

\section{Samlet vurdering}

Ser man på programmene sett under ett er det generelle inntrykket at noen programmer fungerer bedre enn andre når det gjelder profil, administrasjon og drift. En del av forskjellene skyldes utvilsomt forhold som ligger utenfor ansvarsområdet til det enkelte program: For det første er det store forskjeller i størrelsen på programmene - noe som utvilsomt kan være en utfordring når det gjelder saksbehandling og oppfølging. Nordplus Høyere utdanning og Nordplus Junior er - målt i antall søknader - de største programmene, og begge opplever at det kan være en kapasitetsmessig utfordring å håndtere saksbehandlingen på en god måte.

For det andre har noen programmer gjennom mange år hatt en tydelig og avgrenset faglig profil (NSK, Høyere utdanning), mens andre programmer enten er nylig etablert (Horisontal) eller hvor det har vært en innholdsmessig dreining (Junior) som har bidratt til økt kompleksitet og en justering av hva programmet skal være, noe som til en viss grad også kan ha bidratt til større grad av usikkerhet hos potensielle brukere.

For det tredje er det også forskjeller knyttet til hvorvidt de ulike programmer har «konkurrenter» enten i det nordiske samarbeidet eller fra andre aktører herunder EU og deres LLP programmer. Noen brukere nevner eksempelvis at satsingen på «Nordiske Masterprogrammer» er noe man vet andre har vurdert som mer attraktivt enn mer ordinære søknader via Nordplus Høyere Utdanning.

Målt i forhold til ulike kvantitative indikatorer er sentrale funn at det fra 2008 - 2010 har vært en nedgang i antall søknader til mange programmer i Nordplusfamilien (Nordplus Voksen, Høyere utdanning, Junior og til og med det relativt nystartede Horisontal). Deler av denne nedgangen har imidlertid administrative forklaringer. Sett i forhold til bevilgede prosjekter har antallet prosjekter som er støttet imidlertid vært relativt stabilt i programperioden med en liten økning alle programmene sett under ett. Det er med andre ord blitt noe lettere å få innvilget søknader i Nordplus, og sett i et ressursmessig perspektiv er det en tendens til at ressursene som er tilgjengelige fordeles jevnt utover i stedet for konsentreres om færre prosjekter.

Når det gjelder landenes økonomiske «utbytte» av Nordplus synes fordelingen mellom de nordiske land å være relativt lik. I forhold til de baltiske land er det en tendens til at disse landene mottar mer støtte i form av programmidler enn hva de betaler inn til programmet. Det er dog noe variasjon 
mellom programmene i forhold til denne fordelingstendensen. Mobilitet er fremdeles en svært viktig aktivitet rammeprogrammet sett under ett. I 2010 var det nesten 6000 personer som deltok på en slik aktivitet i regi av Nordplus. Generelt er spredningen på mobiliteten god mellom landene. Når det gjelder hvorvidt programmene har hatt prosjekter som har respondert på de innholdsmessige prioriteringer som har vært lagt i programperioden (klima), synes effekten å være relativt beskjeden - med et markant unntak for Nordplus Junior.

Ser man på ressursrammene for de ulike programmer, og antall søknader sett i forhold til de innvilgende prosjekter, er bildet at man i Horisontal og Voksen generelt i programperioden har en høyere avslagsprosent enn for Høyere utdanning, NSK og Junior. Sett i forhold til hva både hovedadministratorene selv rapporterer, oppleves ressursknapphet ikke som et stort problem i alle programmer, og slik sett synes det ikke å være en markert sammenheng mellom ressursrammer og avslagsprosent.

I forhold til styringen av programmene er administratorer, komitémedlemmene og brukere generelt positive til dagens matriseorganisering. De fleste er enige i at denne styringsstrukturen skaper høy grad av medvirkning, tilhørighet og nærhet mellom aktørene. Utfordringen synes å være at høy grad av medvirkning og deltakelse har en pris i forhold til at rammeprogrammene har en relativt dårlig beslutningskraft og informasjonsgjennomsiktighet. Det forhold at hovedkoordinator ikke har noen formell styringsmyndighet bidrar til at iverksettelse av beslutninger tar tid. Ansvaret for felles oppgaver som informasjon, markedsføring og analyser synes også å forvitre i denne styringsstrukturen. Programkomiteene, som i utgangspunktet er de besluttende organ, synes i tillegg å fungere ulikt, og mulighetene for å drive strategisk styring av programmene synes begrenset. Generelt legger hovedadministratorene mange av føringene for de beslutninger som tas. På bakgrunn av denne kompliserte styringsstrukturen er det således noe overraskende å konstatere at selve administrasjonen av Nordplusprogrammene foregår forholdsvis problemfritt når det gjelder selve søknadsbehandlingen og den daglige driftingen av de ulike programmer. Dette synes i stor grad å henge sammen med administratorenes evne til praktisk problemløsning, og deres brede erfaring med Nordplus.

Et generelt inntrykk fra intervjuene med brukere og administratorer er at integreringen av de baltiske land har vært vellykket. For brukere i de baltiske land synes Nordplus å gi flere typer merverdi. For det første gir Nordplus konkret støtte til samarbeidsaktiviteter som synes sterkt ønsket fra baltisk side - knyttet til en genuin interesse for Norden, og til nordisk språk og kultur. For det andre har deltakelsen i Nordplus vært et skritt på veien mot en mer tydelig internasjonalisering - også utenfor det nordiske rom. For det tredje synes man på baltisk side også å ha blitt kjent med en annen måte å samarbeide på, kjennetegnet av en større grad av uformell kontakt og vekt på problemløsning, og der formaliteter, regler og rutiner kanskje ikke er så dominerende. At man fra de baltiske land også mottar mer enn de betaler inn 
til Nordplus, er også en indikasjon på at man fra baltisk side burde si seg fornøyd med deltakelsen.

Profilering av Nordplusprogrammene og spredning av resultatene fra prosjektene har over tid vært en utfordring i Nordplus. I forkant av lanseringen av Nordplus rammeprogram i 2008 ble det derfor satset mye ressurser og tid på markedsføring og informasjonsarbeid. I idag synes dessverre profilering og spredning dessverre fremdeles å være et område hvor det ikke foregår en systematisk eller koordinert innsats, og hvor de initiativer som ble tatt i 2008 ikke har blitt fulgt opp.

Sammenlignet med tilsvarende aktivitet internasjonalt - ikke minst EUs mobilitetsprogrammer (LLP), synes Nordplus fremdeles å ha en relativt gunstig profil. Selv om mange brukere oppfatter at Nordplus er blitt mer «byråkratisk» over tid - ikke minst ved at man har begynt å praktisere regler og rutiner strengere, samt delvis som en følge av at kvalitetskravene til prosjektene er blitt skjerpet inn - synes de fleste brukere likevel å være enige i at Nordplus har mange fordeler sammenlignet med EUs LLP programmer.

I programperioden har funksjonaliteten til det elektroniske søknads- og analyseprogrammet ARS vært svært begrenset. Tanken bak å ha en elektronisk programportal som kan håndtere ulike funksjoner herunder både søknader, informasjon, og analyse, er god og noe både brukere og administratorer er positive til. I 2011 fungerer imidlertid ARS tilfredsstillende når det gjelder søknadsprosessen, og administrasjonen av søknadene, og selv om en del brukere mener at systemet fremdeles lider under en del tekniske feil, opplever majoriteten at systemet ikke er spesielt vanskelig å bruke. Hovedproblemet i dag er først og fremst at analyse og statistikkdelen ikke fungerer godt, og at dette medfører en rekke ulemper for hovedadministratorene.

\section{Tre scenarier for fremtiden}

Evalueringen av Nordplus har gitt sterke indikasjoner på at Nordplus er å regne som en vel fundert og respektert form for samarbeid i det nordiske rom. Både søkere, brukere, administratorer, komitemedlemmer og ulike interessenter har gitt klart uttrykk for at Nordplus er en aktivitet som er verdifull. Den gir merverdi og har en eksistensberettigelse gjennom de temaer som adresseres.

Når det er sagt er det imidlertid mer uenighet om i hvilken retning Nordplus bør utvikle seg i årene som kommer. Synspunktene som er fremmet spenner her vidt og forslagene er til dels mangfoldige. For å stimulere til en mer prinsipiell diskusjon omkring utformingen av Nordplus i årene som kommer er tre noe forskjellige scenarier skissert basert på stikkordene; Konsolidering, Konsentrasjon og Koordinering. Felles for de tre scenariene er at de vektlegger en styrking av den overordnede styringen av Nordplus, og at profilering av programmene og resultatformidling av prosjektene bør forbedres i årene som kommer.

De tre scenariere tar utgangspunkt i den politiske konteksten rundt Nordplus, og de politiske ambisjoner som preger det nordiske samarbeidet i dag. 
- Konsolideringsscenariet er basert på at søkingen etter en balanse mellom gamle og nye formål med Nordplus er noe man må kontinuerlig leve med, der det viktigste er å justere styringen av rammeprogrammet, samt gjøre mindre justeringer i programinndeling, og styrke profileringen og resultatformidlingen.

- Konsentrasjonsscenariet argumenterer imidlertid mer for at innebygde spenninger i Nordplus over tid kan være ødeleggende for fokus og gjennomslag for programmene, og at veksten og den økte kompleksiteten i programmene må håndteres gjennom en sterkere styring og prioritering i programmene og der en også vurderer programstrukturen mer kritisk, enten i forhold til målgrupper, virkemidler eller i kombinasjoner av dette.

- Koordineringsscenariet kan på sin side sies å være svaret på den økte oppmerksomhet utdanningsspørsmål etter hvert har fått i Norden ikke minst gjennom det såkalte globaliseringsinitiativet - og behovet for økt profesjonalitet rundt håndteringen av slike spørsmål. I dette perspektivet ser man dermed på utviklingstrekk også utenfor Nordplus, men som kan ha betydning for hvorvidt dagens programorganisering er den mest hensiktsmessige måten å håndtere disse på. 



\section{Bakgrunn og utgangspunkt for evalueringen}

Nordplus som programaktivitet startet med Nordplus Høyere utdanning i 1988, og feiret sitt 20 års jubileum som mobilitetsprogram ved inngangen til det rammeprogram som ble igangsatt i 2008. Overgangen til den nye programperioden kan ses som viktig på flere måter. Etableringen av et nytt rammeprogram i 2008 markerte at Nordplus ikke bare var en faglig møteplass og et mobilitetsprogram, men også et redskap for å realisere politiske ambisjoner om videreutvikling av de nordiske lands utdanningssystemer.

Nordisk ministerråd besluttet i 2009 å igangsette en evaluering av Nordisk Rammeprogram og Nordplus Nordiske Språk- og Kulturprogram (NSK). Dette er Nordisk ministerråds største utdanningsprogrammer innenfor livslang læring. Nordisk Rammeprogram omfatter fire delprogram

- Nordplus Junior

- Nordplus Horisontal

- Nordplus Høyere utdanning

- Nordplus Voksen.

Rammeprogrammet og NSK ble i sin nåværende form iverksatt fra januar 2008, og har en vedtatt programperiode til og med desember 2011. Før 2008 besto Nordplus av tre sektorprogrammer: Junior, Voksen og Høyere utdanning, i tillegg til Nordplus Språk og Nordplus Nabo som vektla samarbeidsprosjekter med Russland og de baltiske land. Hvert av disse programmene hadde sine egne regler, formål og administrative rutiner. I det nye Nordplusprogrammet som ble iverksatt fra 2008 deltok for også første gang de baltiske landene, Estland, Latvia og Litauen på like fot i et felles Nordplus Rammeprogram (dog uten formell innflytelse på den overordnede styringen av programmet). NSK ble besluttet videreført, men som et eget program uten baltisk deltakelse.

De overordnede målsettingene for Nordplus er å:

- Fremme nordisk språk og kultur og gjensidig nordisk-baltisk språklig og kulturell forståelse

- Bidra til utviklingen av kvalitet og innovasjon i utdanningssystemene for livslang læring i deltakerlandene gjennom utdanningssamarbeid, utviklingsprosjekter, utveksling og nettverksbygging

- Støtte, bygge på, dra nytte av og spre innovative produkter og prosesser på utdanningsområdet gjennom systematisk utveksling av erfaringer og god praksis 
- Styrke og utvikle det nordiske utdanningssamarbeidet og bidra til å skape et nordisk-baltisk utdanningsområde.

\subsection{Sentrale perspektiver og spørsmål i evalueringen av Nordplus}

Evalueringen av Nordplusprogrammene har som formål å danne et grunnlag for en eventuell videreføring av Nordplus programmene etter 2011. Gjennom analyse av programperioden 2008-2011 skal evalueringen belyse fremtidige innholdsmessige og administrative utviklingsmuligheter for programmene. Ikke minst er det viktig å gi en vurdering av hvordan programmene har fungert i perioden og hvilke resultater som er oppnådd i forhold til de overordnede målsettinger for programmet som ble innført i 2008. Evalueringen skal vise hvorvidt det er behov for endringer i programvirksomheten.

Mer spesifikt skal evalueringen gi svar på følgende spørsmål:

1) Hvordan har programmene fungert i programperioden, herunder blant annet programstrukturen og programkomiteene?

2) Hvilke resultater er oppnådd sett i forhold til de overordnede målsettingene med innføring av de nye programmene?

3) Hvordan har integreringen av de baltiske landene lykkes?

4) Hvordan er profilering, spredning og oppfølging av erfaringer og resultater fra programmene gjennomført?

5) Hvordan har administrasjonen av programmene fungert, herunder blant annet det elektroniske søknads- og rapporteringssystemet (ARS)?

Ser man nevnte spørsmål i sammenheng med de overordnede målene for Nordplus samarbeidet blir det tydelig at man må evaluere Nordplus initiativet ut fra flere til dels overlappende perspektiver.

Et første perspektiv kan koples mer til de grunnleggende intensjoner bak etableringen av Nordplusamarbeidet, og ambisjonene om økt språklig og kulturell forståelse i det nordiske rom. I dette perspektivet vil resultater ikke bare være materielle, men også knyttet til kunnskap, interesse og motivasjon for å realisere slike ambisjoner. Informasjonsspredning, profilering og legitimering er sentrale stikkord for å oppnå dette. Dette perspektivet har gjentatte ganger vært nevnt vært en grunnleggende drivkraft bak det nordisk samarbeidet, og ble igjen understreket i det Ministerrådsforslag som lå til grunn for opprettelsen av Nordplus programmene i perioden fra 2008-2011. Her heter det ikke minst at Nordplus er et viktig redskap for å fremme «utvikling av deltakerlandenes kultur, språk og verdifellesskap» (Nordisk Råd 2006: 1$)$.

Det andre perspektivet er knyttet til Nordplus som utdannings- og mobilitetsprogram. Målsettingene med Nordplus handler primært om mobilitet, utveksling og samarbeid mellom aktører i de nordiske land, og om de res- 
surser som er bevilget til dette formålet brukes hensiktsmessig og effektivt. Skal man eksempelvis bidra til å styrke og utvikle det nordiske utdanningssamarbeidet må man faktisk også kunne identifisere konkrete resultater av dette i form av aktører som faktisk deltar i Nordplus. Dette hensynet kan også gjenfinnes i de politiske intensjonene bak det nye Nordplus programmet for perioden 2008-2011. Ikke minst heter det i det Ministerrådsforslag som lå til grunn for opprettelsen av det nye programmet at en viktig og overordnet målsetting med Nordplus skal være å «styrke og utvikle det nordiske utdanningssamarbeidet og bidra til å skape et nordisk-baltisk utdanningsområde» (Nordisk Råd 2006: 3). Mobilitetsprogrammer kan sies å være den konkrete operasjonaliseringen av et slikt geografisk definert utdanningsområde, og der spesielt Junior kan sies å spille en viktig rolle som en slags «døråpner» også for utveksling og samarbeid senere.

Det tredje perspektivet kan sies på bygge på det foregående, der man har forhåpninger om at selve utvekslingen og økt mobilitet også skal lede frem til nyskapning, innovasjon og spredning av god praksis når det gjelder utdanning og læring i Norden og Baltikum. Denne målsettingen har sin bakgrunn i flere politiske initiativ i Norden i de seneste ti årene, herunder diskusjonsopplegget «Norden som global vinnerregion» i 2005, og i Ministerrådets strategi «Norden som foregangsregion for utvikling av mennesklige ressurser» i perioden 2005-2007. Slik sett er det eksempelvis viktig at de prosjekter som blir selektert har et potensial for å bidra til en slik utvikling, alternativt at de bidrar til etablering av nettverk som kan fungere som drivere i en slik prosess. I de seneste årene er dette siste perspektivet blitt enda viktigere i det nordiske samarbeidet, ikke minst som en følge av det Globaliseringsinitiativ som de nordiske statsministre lanserte i 2007, og som senere er fulgt opp gjennom årlige globaliseringskonferanser og ulike tiltak og aktiviteter på en rekke felter. Innen utdanningsfeltet er kanskje det mest markante initiativet de nordiske masterprogrammene som ble implementert i 2007 som en direkte følge av globaliseringsinitiativet, og som sett i lys av søkerinteressen fra nordiske universitet og høyskoler, synes å være en stor suksess.

De politiske overveielser som la til grunn for det nye Nordplus programmet i 2008 synes da også i stor grad å legge til grunn at Nordplus burde ivareta både «kontinuitet og fornyelse» (Nordisk Råd 2006: 1). Kontinuiteten synes i det nye programmet å skulle være ivaretatt ved en videreføring av sektorprogrammene som hadde eksistert tidligere (Høyere utdanning, Voksen og Junior), og mange av aktivitetene i disse, mens fornyelsen skulle skje gjennom opprettelsen av en nytt tverrsektorielt program (Horisontal), gjennom en inkludering av Estland, Litauen og Latvia som nye land i samarbeidet, samt gjennom en rekke endringer i styring, organisering og drift av rammeprogrammet, ikke minst som en følge av at de baltiske land ble med i Nordplus.

Inkluderingen av de baltiske land medførte særlige utfordringer for Nordplus. Med hensyn til overordnet styring ble det understreket at Nordplus 
fremdeles skulle være formelt eid av de nordiske land, mens man «åpnet for deltakelse» fra de baltiske land (Nordisk Råd 2006: 4). Samtidig skulle samarbeidet også være «likeverdig» - noe som ble understreket gjennom etablering av programkomiteer med baltisk deltakelse, samt at de baltiske land ble med på å betale inn til Nordplus ut fra de samme bidragsmodell (knyttet til landenes BNI) som gjaldt for de nordiske land - noe som dermed ga en økt budsjettramme til Nordplus totalt sett. I forhold til organisering ble det imidlertid kun opprettet nasjonale informasjonskontor i de baltiske land, mens de eksisterende nordiske land skulle ivareta de formelle hovedadministrasjonsoppgavene for de respektive programmer.

Selv om det politiske utgangspunktet for Nordplus fremdeles har stor gyldighet, har altså den politiske konteksten over tid endret seg, og brakt inn nye forventninger og ønsker knyttet til hva slags program Nordplus skal være. Selv om nye forventninger ikke nødvendigvis innebærer et brudd med fortiden, bør det imidlertid understrekes at et samarbeid med så mange innebygde dimensjoner og målsettinger også kan være potensielt motsetningsfylt (se også figur 1).

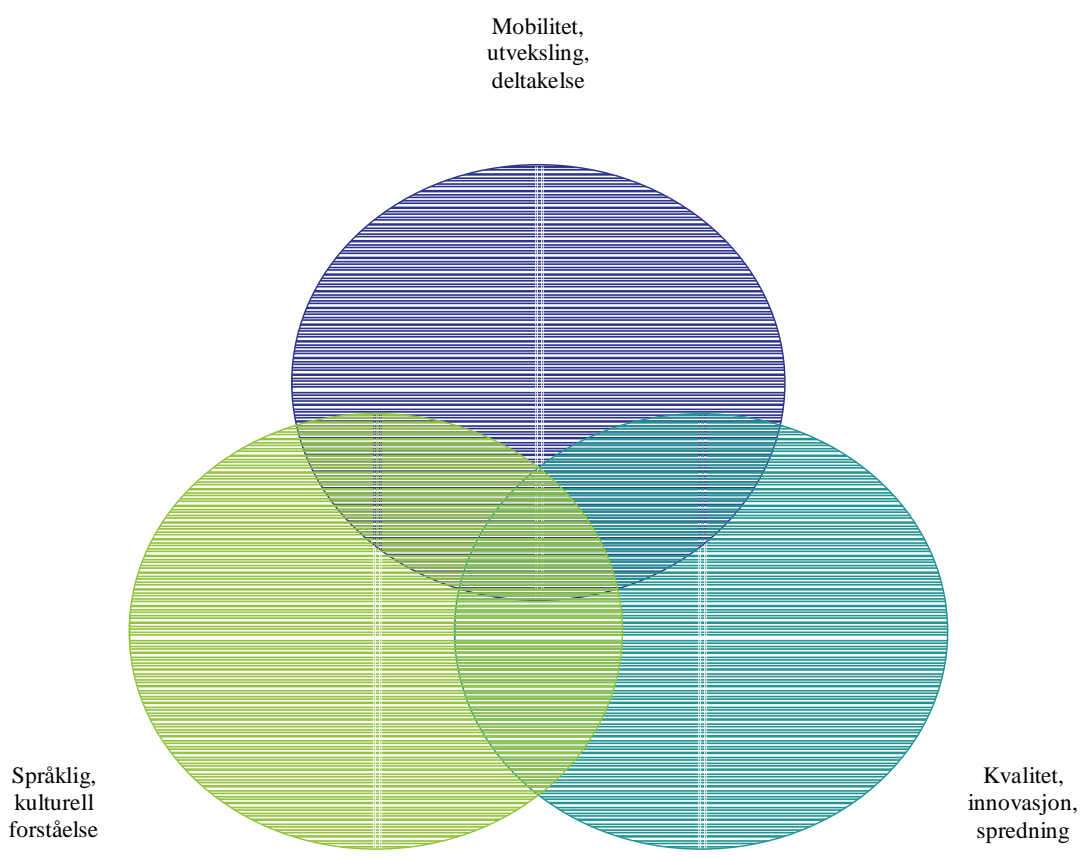

Figur 1: Målsettinger og potensielle spenningsfelter i Nordplus samarbeidet

Nordplus handler med andre ord ikke lenger bare om samarbeid mellom lærestedene om utveksling av studenter og lærere. Nordplus er blitt et redskap for innfrielsen av en rekke politiske mål som berører alle deler av utdanningssektoren. Nordplus samarbeidet kompliseres ytterligere ved at perspektivene ikke bare må balanseres, men denne balansen må i tillegg skapes gjennom en kompleks organisering og drifting av programmet der aktører fra ulike har ulike roller, men tildels overlappende ansvar. I forleng- 
elsen av inkluderingen av de baltiske land i Nordplus-samarbeidet, og ikke minst i lys av globaliseringsinitiativet, kan både grensene for og formålet med nordisk utdanningssamarbeid sies å være utfordret. I denne evalueringen skal vi komme tilbake til noen av disse mer overordnede utfordringene i det avsluttende kapittelet.

\subsubsection{Organisering og drift av Nordplus 2008-2011}

Dagens organisering av Nordplus er forskjellig fra tidligere former for organisering, selv om det også er mulig å se at dagens modell har ivaretatt trekk ved tidligere organiseringsmodeller (Vabø 2006). Mens Nordplus i mange år var organisert relativt sentralisert, ble dette endret i 2004 der sentrale trekk ved dagens ordning ble utviklet, og en mer desentralisert modell etablert. Dagens Nordplusorganisering består av et konsortium med en hovedkoordinator, samt fem hovedadministratorer - en fra hvert av de nordiske land (se figur 2).

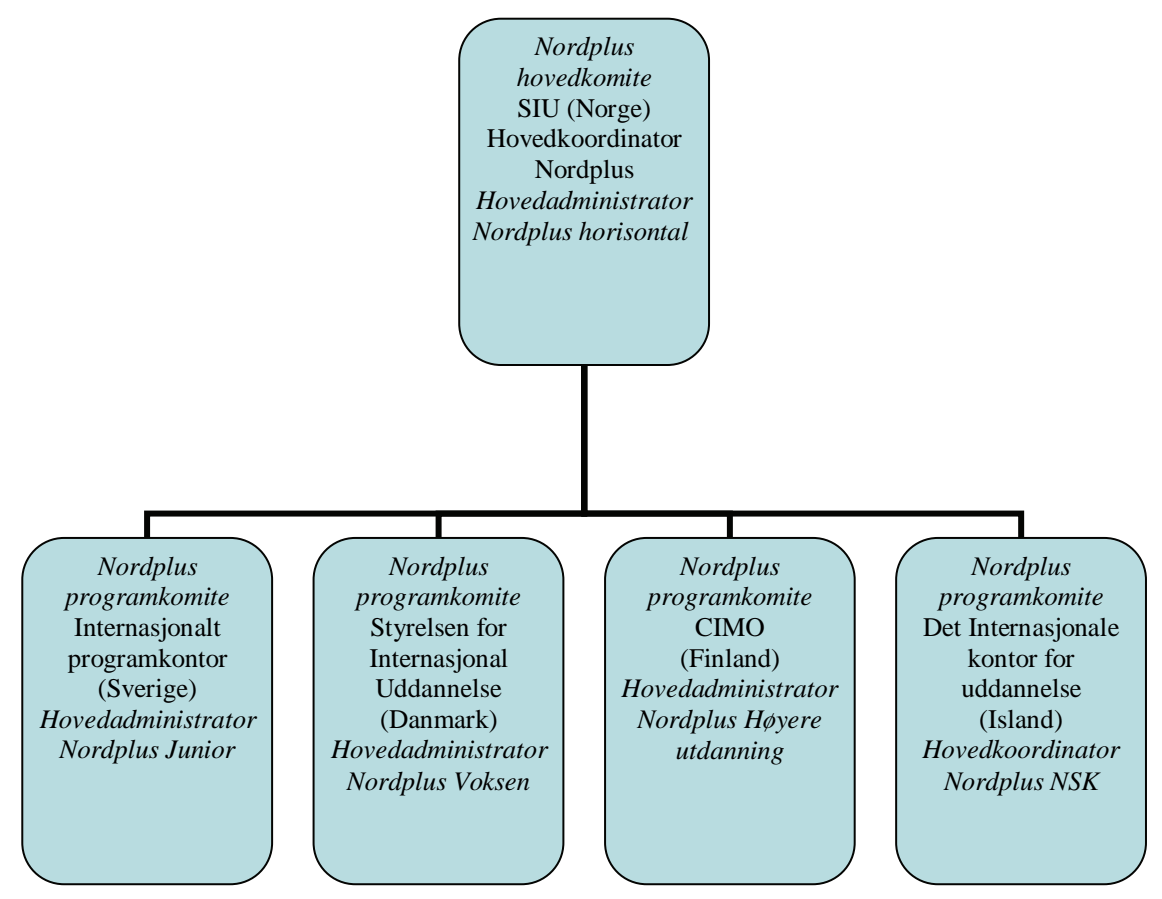

Figur 2: Organisering av Nordplus

Disse hovedadministratorene har ansvaret for hvert sitt delprogram, og der NSK i praksis er integrert i styrings- og administrasjonsmodellen. Rollen som hovedkoordinator kan alternere mellom de fem hovedkoordinatorene, og i inneværende periode er et SIU i Norge som har hatt dette ansvaret. I tillegg til å ha hovedansvaret for hvert sitt program, er imidlertid også de fem hovedadministratorene delansvarlige for informasjon og drift av de andre delprogrammene i eget land. 
I forhold til de Baltiske land har de nasjonale informasjonskontorene i Estland, Latvia og Litauen ansvaret for informasjon om Nordplus Rammeprogram. I de selvstyrte områdene har hovedkoordinatorene i henholdsvis Danmark og Finland et ansvar for Grønland og Færøyene, samt for Åland.

Når det gjelder beslutningsstrukturen i Nordplusamarbeidet er den basert på ulike komiteer. Hovedprogramkomiteen har et overordnet ansvar for Nordplus Rammeprogram og for Nordplus Horisontal. I tillegg eksisterer det egne programkomiteer for Nordplus Junior, Voksen og Høyere utdanning. I tillegg har de enkelte delprogrammer også rådgivende komiteer å trekke veksler på i sitt arbeid (HØGUT, SVL, NSS og NSR).

For NSK er det Nordisk Språkråd (NSR) som ivaretar beslutningsfunksjonene. Komiteene har et ansvar for å utvikle prioriteringer og for utvikling av det enkelte program. Hovedadministratorene fungerer som sekretariater for de ulike programkomiteene. Hovedkoordinator for Nordplus har ansvaret for å ivareta kontakt og kommunikasjon med Nordisk ministerråd som formell oppdragsgiver. Det bør understrekes at NSK ikke er en formell del av Nordplus samarbeidet, selv om man har inkludert programmet i dagens organisasjonsstruktur. De Baltiske land er ikke inkludert i dette samarbeidet grunnet programmets profil.

\subsubsection{Noen innrapporterte problemer fra driften i 2008-2009}

Som et ledd i den nye organiserings- og styringsstrukturen tok man i 2008 i bruk et nytt felles IKT-basert søknads- og rapporteringssystem - ARS - der hensikten var å utnytte stordriftsfordeler når det gjaldt behandling og vurdering av søknader. Dette systemet har så langt skapt en del frustrasjon og merarbeid for de involverte (SIU 2009). Selv om mange problemer nå synes å være løst, er det likevel ikke hovedkoordinators mening at systemet fungerer tilfredsstillende. Det antydes at problemer med ARS kan ha hatt negative konsekvenser for omdømmet til Nordplus generelt.

\subsection{Data, metode og vurderingsgrunnlag}

Mandatet for evalueringen impliserer en anvendelse av både formative og summative evalueringsmetodikker. Formative ettersom evalueringen skal bidra til læring og anbefalinger for videre utvikling. Summative ettersom den også skal inneholde analyse av oppnådde resultater.

Programvirksomhet for internasjonalt samarbeid og utveksling i utdanningssammenheng blir gjerne evaluert i forhold til noen basale indikatorer; hvor mange har søkt, hvor mange har fătt innfridd søknaden, hvor mange har deltatt og hvor god er spredningen i forhold til ulike variabler. Denne type informasjon er forsøkt systematisert både i de enkelte kapitler som omhandler de ulike program, men også i kapittel 8 der man sammenligner programmene på tvers. I denne sammenheng er en viktig dimensjon utvikling 
over tid for derigjennom å si noe om man er på rett vei i henhold til de spesifiserte målsettinger.

Samtidig kan endel resultater være vanskelige å gjøre til gjenstand for entydig fortolkning, herunder hvorvidt Nordplus fremmer nordisk språklig og kulturell forståelse, eller bidrar til prosesser og innovasjon som utvikler utdanningsfeltet. Her har vi søkt å validisere data og vurderinger på ulike måter. En viktig metodikk er knyttet til triangulering - der informasjon og synspunkter innhentes fra ulike kilder og ståsteder, og der man på grunnlag av en rekke ulike data forsøker å skape et mer overordnet bilde. For å få til en god triangulering av data, er evalueringsdesignet basert på desk-research, kvantitative data og analyser, egenrapportering og besøk og intervjuer hos ulike aktører og deltakere i samarbeidet. Grunnet at Nordplus samarbeidet har blitt utvidet både geografisk og tematisk, har man imidlertid vært nødt til å foreta noen prioriteringer i datainnsamlingsarbeidet. For å ivareta utviklingshensynet har man ønsket å prioritere å få økt kunnskap om gode praksiser og erfaringer innenfor det enkelte program - synliggjort ved en spesiell strategisk valgt case-studie. Dette er et case som er valgt ut i konsultasjon med hovedadministrator for programmet, men der NIFU i tillegg har vært i direkte kontakt med brukerne.

En annen måte å styrke vurderingsgrunnlaget har vært knyttet til å be informanter om å sammenligne Nordplusprogrammene med andre tilsvarende program - først og fremst EUs LLP programmer. LLP består av fire delprogrammer (Comenius, Leonardo da Vinci, Erasmus og Grundtvig) - med en profil som ofte tilsvarer Nordplus programmene. Dette har vært nyttig både for å sammenligne innhold og administrering av programmene.

Evalueringen har også sett nærmere på ressursmessige data - både på landnivå, programnivå og på prosjektnivå. Her har imidlertid datagrunnlaget vært mangelfullt på program- og prosjektnivå. Evalueringen har derfor hatt begrenset mulighet for systematiske analyser på dette nivået. I forhold til ressursinnbetaling og fordeling på landnivå gjøres det en vurdering av dette $\mathrm{i}$ kapittel 8.

Samtidig har man i datainnsamlingen forsøkt å involvere relevante oppdragsgivere, målgrupper og samarbeidspartnere i evalueringsprosessen enten personlig, via e-post eller per telefon. I tillegg til representanter for programkomiteene, Nordisk ministerråds sekretariat og programforvalterne i de respektive deltakerland, gjelder dette også representanter for universiteter og høyskoler, grunn - og videregående skoler, samt andre aktører som kan ha interesse i Nordplus, eksempelvis fra Foreningen Norden. Informasjon har også vært innhentet fra interesseorganisasjoner for voksnes læring og andre brukere av Nordplus Voksen.

Med tanke på at de baltiske land fremdeles er i en implementeringsfase har vi også valgt å gjøre relativt mange intervjuer i Estland, Latvia, Litauen. Til sammen er nærmere 80 personer intervjuet totalt som en del av evalueringen, der omtrent halvparten har vært brukerrepresentanter fordelt på de 8 deltakende land, og selvstyrte områder (Grønland, Åland og Færøyene). Her 
har kvalitative intervjuer vært foretrukket fremfor en større kvantitativ survey ut fra at evalueringen har dekket en bred vifte av problemstillinger noe som ville krevd et meget omfattende og sofistikert spørreskjema. Ulempen med denne tilnærmingen er at man har mindre kunnskap om gyldigheten av synspunkter mer generelt hos brukerne. Ved hjelp av triangulering mellom ulike typer informanter innen samme program mener vi likevel at mer overordnede tendenser er avdekket.

NIFU har i tillegg forsøkt å synliggjøre dette datamaterialet gjennom en utstrakt bruk av sitater i teksten. Sitatene er imidlertid anonymisert, ikke minst for å stimulere til mer åpenhet under intervjuene.

Tabell 1.1: Oversikt over datakilder, analyser og deres relasjon til mandatet for evalueringen

\begin{tabular}{ll}
\hline Kilder & Hvordan disse vil besvare sentrale tema i evalueringen av Nordplus \\
\hline Selvevaluering & Forholdet mellom mål, organisering, administrasjon aktiviteter og \\
& resultater. \\
Dokumentanalyse & Generell informasjon om programvirksomhetene, analyse av \\
& resultater, analyse av informasjonsstrategi. Profilering og spred- \\
& ning. \\
Intervjuer & Vurdering av integrering i de baltiske land, administrasjon av \\
& programmet \\
Komparative analyser & Resultater, relevans, effekter av profilering, spredning. \\
\hline
\end{tabular}

Evalueringen har også som oppdrag å tenke høyt omkring fremtiden til Nordplus, og NIFU har i denne forbindelse aktivt forsøkt å innhente synspunkt om fremtidig innretning av Nordplus hos de aktører som er aktive partnere og deltakere i programmene. Vårt bidrag i denne forbindelse har vært å forsøke å gi slike tanker en mer prinsipiell overbygning i form av ulike scenarier for Nordplus (se kap. 9).

\subsection{Organisering av rapporten}

Rapporten er organisert i ni kapitler, der de ulike programmene i Nordplusfamilien er beskrevet og vurdert i kapittel 2-6. I rapporten har vi også valgt å utforme et eget kapittel der synspunkter fra de baltiske land søkes oppsummert mer samlet (kapittel 7). I kapittel 8 gjøres det ulike sammenfattende og tverrgående sammenligninger mellom programmene, før vi i kapittel 9 skisserer noen mulige utviklingsscenarier for Nordplus i årene som kommer. 


\section{Nordplus Horisontal}

\subsection{Innledning}

Nordplus Horisontal er det nyeste programmet i Nordplus familien, og er fremdeles et forholdsvis lite program, både målt i antall søknader og i de ressurser man rår over. Programmet har som formål - som navnet indikerer - å være et grenseoverskridende initiativ der ikke utdanningsnivå eller type aktiviteter skal utgjøre begrensninger for aktiviteten.

Ifølge prosjektbeskrivelsen for Nordplus Horisontal heter det at programmet skal støtte innovative prosjekter på tvers av tradisjonelle kategorier og sektorer, spesielt prosjekter som kan ta opp andre, nye, bredere og mer komplekse problemstillinger og utfordringer. Programmet retter seg mot alle institusjoner og organisasjoner som arbeider hovedsakelig innenfor feltet utdanning og livslang læring. En søknad om støtte til prosjekt- og nettverksaktiviteter fra Nordplus Horisontal må involvere minimum to sektorer. Den kan omfatte samarbeid mellom to sektorer fra utdanningssystemet, for eksempel mellom Høyere utdannings- og grunnskolesektoren, eller mellom organisasjoner, institusjoner og bedrifter på tvers av offentlig, privat og/eller frivillig sektor. Forutsetning er at det er utdanningssamarbeid det søkes støtte til. Aktivitetene må også involvere minimum tre partnere fra tre ulike deltakerland. Søknaden kan også inkludere deltakere fra land utenfor Norden og Baltikum. Disse må være ansett som relevante av nettverket eller prosjektpartnerne.

Således kan programmet støtte en rekke ulike tiltak:

- Seminarer og workshops

- Erfaringsutvekslingsseminar

- Konferanser

- Analyser og utredninger

- Statistikkutvikling og -analyse

- Forskning basert på utnytting av eksisterende data

- Utvikling av nyskapende (språk)utdanning, lærings- og oversettingsmateriale

- Utvikling av nye kurs og undervisningsmoduler basert på ny teknologi

- Formidling og utveksling av erfaringer knyttet til utdanning og læring 


\subsection{Styringsstruktur og ressurser}

Det generelle inntrykket er at dagens organisasjonsmodell med hovedadministrator og medadministratoroppgaver fordelt på de ulike nordiske land fungerer godt for Horisontalprogrammet. Generelt synes organisasjonsmodellen å avspeile etablerte kulturelle tradisjoner for samarbeid i Norden, der verdier som konsensus, dialog og gjensidighet står sterkt. Av konkrete fordeler som nevnes som et resultat av denne organiseringsformen er god kvalitetssikring av prosjektsøknader, samt at informasjons- og profileringsarbeidet kan målrettes bedre til den nasjonale konteksten.

Utfordringen synes å være at et slikt prosessorientert perspektiv ofte vil komme på kollisjonskurs i forhold til en sterk handlings- og resultatorientering. Dagens matriseorganisering vil generelt ha større koordinerings- og styringskostnader enn organisasjonsmodeller med kortere og enklere ansvars- og myndighetslinjer. Ikke minst synes dette å komme til uttrykk når det gjelder spørsmål om ansvars- og myndighetsfordeling mellom hovedadministrator, programkomiteen for Horisontal (som er identisk med hovedkomiteen for Nordplus), NMRs sekretariat og Embetsmannskomiteen. Her synes det å råde en viss usikkerhet knyttet til hvilke organ som i praksis bestemmer hva. Samtidig er denne frustrasjonen ikke et uttrykk for manglende samarbeidsklima - som beskrives som godt og konstruktivt.

Slik sett er dagens organisasjonsmodell relativt tids- og ressurskrevende, og det er hovedadministrators vurdering at administrasjonsressursene ikke er i samsvar med de krav som rettes til informasjon, kvalitetssikring og rapportering fra prosjektene. Samtidig kan ikke organiseringen av Nordplus Horisontal ses isolert fra de andre programmene i Nordplusamarbeidet, og gitt kompleksiteten knyttet til samordning av dagens Nordplusprogrammer, synes sentrale aktører å være fornøyd med eksisterende modell.

Ser man nærmere på programmidlene og antall søknader innenfor Nordplus Horisontal er hovedadministrator rimelig fornøyd med ressurssituasjonen. Denne vurderingen synes å være betinget av en holdning om at kvaliteten på innvilgende prosjekter skal være god. Sett over tid har suksessraten likevel variert noe - fra 46 prosent i 2008 til 63 prosent i 2010.

Mange brukere har påpekt at kravet om 50 prosent egenfinansiering er en utfordring - spesielt på skolesiden der det rapporteres om svært begrensede midler som kan avsettes til denne type prosjekter, og der man i liten grad har hatt evne til å komme opp med kreative forslag til hvordan egenandelen kan dekkes inn.

Av spesielle utfordringer for Nordplus Horisontal nevnes at dette er et nytt og relativt avgrenset program sammenlignet med de andre programtilbudene. Uklarheter om målgrupper, sektorer og temaer gjør at Horisontal både er vanskeligere å markedsføre, samt at søknadene som kommer inn er vanskeligere å sammenligne. Hovedadministrator opplever at det har vært gjort mye «fotarbeid» knyttet til å definere hva programmet skal handle om, hva slags profil det skal ha, hvordan man kan få utviklet felles forståelser av hva som 
kan defineres som «tverr-sektorielt», etc. Hovedadministrator mener imidlertid at dette har «gått seg til» over tid, og at Horisontal både er blitt mer kjent og profilert som et selvstendig program i Nordplus familien. Dette er et synspunkt som både brukere og medadministratorer i andre land synes å dele. Et typisk utsagn fra en bruker av programmet kan illustrere dette:

Nordplus Horisontal er jo på mange måter det programmet som vi har savnet i Nordplusfamilien. Vi var jo tidligere i Nordplus Høyere utdanning, men etter at vi ble oppmerksom på frihetsgradene i Horisontal bestemte vi oss til å «flytte over», og det har vi ikke angret på. Horisontal har vært et friskt pust både for Nordplus, men ikke minst for vår egen tenkning.

Inkluderingen av de baltiske land oppleves som uproblematisk i Nordplus Horisontal. Det påpekes at den største endringen antakelig er av språklig art siden kommunikasjonen må foregå på engelsk. Ved siden av dette erfarte man også endel innkjøringsproblemer knyttet til implementeringsfasen (veiledning, informasjon, søknadsprosessen, etc), men i dag synes de baltiske land å være godt integrert i Horisontal der de også oppleves som verdifulle tilvekster til samarbeidet. Sammenlignet med andre programmer er den Baltiske deltakelsen i Horisontal relativt høy, og både representanter for brukere i Baltikum og synspunkter fra øvrige nordiske land indikerer stor entusiasme knyttet til balternes inntreden i programmet. En forklaring på denne entusiasmen synes å være at siden Horisontal er et nytt program i Nordplus familien har det vært enklere å bli integrert i programmet. Nettverkene som skapes er nye og ikke så etablerte som i en del av de andre programmene, og det bidrar til at terskelen knyttet til deltakelse og engasjement blir lavere.

\subsection{Administrasjon og drift av programmet}

I forhold til driften og administrasjonen av programmet synes det ikke å ha vært spesielle problemer knyttet til Horisontal. Som antydet synes vurderingene av søknader til programmet å ha vært en utfordring i starten av programmet ut fra at programmets tverrsektorielle karakter gjorde sammenligning og prioritering vanskelig. I starten synes man å ha vært veldig fokusert på de formelle kriteriene for deltakelse, mens man i senere runder har vært mer opptatt av å gjøre substansvurderinger knyttet til hva prosjektet har ambisjoner om, og hvordan man har organisert seg for å få det til i praksis.

Siden programkomiteen for Horisontal er den samme som hovedkomiteen for Nordplus har komiteens involvering i Horisontal vært begrenset. I realiteten betyr dette at hovedadministrator har hatt stor innflytelse i forhold til fortolkningen og implementeringen av programmet. Samtidig synes det også å ha vært en del uformell kontakt mellom hovedadministrator og NMRs sekretariat i København knyttet til hvordan en del praktiske utfordringer burde håndteres. Hovedadministrator - som også er hovedkoordinator i Nordplusamarbeidet - har imidlertid hatt mest innflytelse over program- 
met. Dette betyr imidlertid ikke at medadministratorene ikke har medvirket i drifts- og kvalitetssikringsfasen, som synes å ha fungert uproblematisk. På mange måter er det akkurat på denne type prosesser at hoved- og medadministratorene har stor erfaring og profesjonalitet, og Horisontal har ikke medført noen spesielle utfordringer i så måte. Denne formen for organisering gjennom at ulike aktører har et medansvaret øker muligheten for også å kunne lære av hverandres erfaringer.

Sett fra et brukerståsted oppleves Horisontal relativt uproblematisk. Noen brukere klager over at håndboken er for standardisert og at en del detaljinformasjon mangler - samtidig synes de også at håndboken er et hjelpemiddel som svarer på mange av standardspørsmålene knyttet til finansiering og budsjettering, rapporering og utvelgelseskriterier. Saksbehandlingstid og tilgjengelighet knyttet til å få svar fra hoved- og medadministratorer omkring deres søknader er de generelt også tilfreds med. Som en av brukerne i Horisontal sier:

Vi er jo deltakere både i EUs LLP programmer og i Horisontal, og sammenligner man disse to programmene er jo Horisontal langt mer fleksibelt - vi kan jo i større grad «forhandle» med SIU selv om de selvfølgelig er strikte på formelle tidsfrister.

En annen bruker synes å dele disse synspunktene der man hevder at:

Hele Nordplus er jo blitt mer formalistisk gjennom årene. Dette er delvis en konsekvens av at rammeprogrammet har vokst i både bredde og dybde. Horisontal og den fleksibilitet som er innebygget i dette programmet synes jeg minner om «gamle» Nordplus hvor nettopp pragmatisme og fleksibilitet var sentrale kjennetegn.

I forhold til det elektroniske søknads- og rapporteringssystemet ARS har man i Nordplus Horisontal opplevd store innkjøringsproblemer både sett fra et administrativt og et brukersynspunkt. Fra et sakshandlerståsted rapporteres det at det er vanskelig å bruke systemet, og også vanskelig å hente ut den informasjon (statistikk, etc.) som man har behov for. Vanskelighetene forklares både som et resultat av hvordan ARS er bygd opp, og at systemet rent teknisk ikke har fungert. Fremdeles mener hovedadministrator at systemet ikke fungerer etter hensikten i forhold til analyse og rapportering. Når det gjelder søknadsinnlegging synes alle problemer å være løst.

Sett fra et brukersynspunkt er man i stor grad enig i dette, og i dag synes det ikke å være spesielle hindre når det gjelder funksjonaliteten. At man opererer med den samme «portal» for alle programmer synes brukerne er svært hensiktsmessig - og noe som også gjør at man lettere blir oppmerksom på andre program. Det som en del brukere av Horisontal ønsker seg i ARS er en mer rikholdig database over mulige partnere, samt en prosjektdatabase. At alle programmer opererer med ARS har imidlertid sine fordeler både sett fra et administrativt og et brukerståsted, og slik sett er en viktig målsetting med systemet i ferd med å bli oppfylt. 


\subsection{Profilering, spredning og informasjonsarbeid}

Siden Horisontal i utgangspunktet er et «åpent» program har informasjonsog profileringsarbeidet vært en utfordring. Strategien som har vært valgt fra hovedadministrator har vært å legge ved informasjon om Horisontal sammen med informasjonen fra de andre Nordplusprogrammene. På den måten har man håpet å vise at søknader som ikke alltid «passer inn» i et av de andre programmene, kanskje kan omarbeides til et Horisontal prosjekt. I tillegg til den informasjon som har gått ut via de andre programsatsingene, er det delt ut rundt 3000 brosjyrer om Nordplus Horisontal direkte til aktuelle organisasjoner og aktører på feltet i ulike land.

Denne informasjonsspredningsstrategien er forståelig men synes samtidig å ha hatt som effekt at brukerne kanskje ikke alltid har oppfattet Horisontal som et nytt program:

Det synes jo som om Horisontal både er et «samleprogram»» for alt som faller utenfor de andre Nordplus programmene, samtidig som Horisontal også skal representere en viktig nytenkning og fornyelse i Nordplus - klart det er en vanskelig balansegang.

Mange brukere av Horisontal synes opprinnelig å ha hatt en relasjon til et annet program. Flere brukere sier at dette har preget deres tenkning i prosjektutviklingsfasen og at prosjektene dermed ikke var så tilpasset Horisontal som ønskelig. Samtidig påpeker mange av de samme brukerne at de over tid ser at Horisontal innebærer nye muligheter, og at de i større grad ser begrensningene som preget prosjektene opprinnelig. Utsagnene tyder på at Horisontal fremdeles har et innovasjonspotensial som ikke er fullt ut utnyttet.

\subsection{Måloppnåelse og resultater}

I Nordplus Horisontal var det i 200846 søknader hvorav 21 ble innvilget. I 2009 hadde programmet 35 søknader hvorav 18 ble innvilget, men man i 2010 hadde 32 søknader og der 20 av disse ble innvilget. Generelt er suksessraten i Horisontal lavere enn for de andre programmene (unntatt Voksen), og synes å ha en sammenheng med at søknader i Horisontal er relativt omfattende og større enn for de andre Nordplus programmene. Dette har den effekt at innvilgende søknader gjør relativt store innhogg i ressursene til rådighet. I snitt har rundt halvparten av søknadene til Horisontal en varighet på mer enn ett år, med et gjennomsnittslig søknadsbeløp på 43400 Euro. Innvilgede prosjekter har en gjennomsnittlig størrelse på 55000 Euro. Tilsvarende har innvilgende prosjekter flere partnere $(6,6)$ enn det totale søkerantallet $(4,6)$.

Bildet er altså at innvilgede prosjekter både er større og har flere partnere enn gjennomsnittet for søknadene. Dette er imidlertid delvis ses som en konsekvens av formålet med Horisontal der man jo skal bygge bro mellom ulike nivåer og aktører. At nettverkene dermed blir større og mer komplekse 
er ikke unaturlig. Generelt er det også slik at det er institusjoner innen Høyere utdanning i hovedsak som var leder/koordinator av prosjektene i den tidlige fasen av Horisontal, selv om skolenivået er godt representert på partnersiden. Senere er andre aktører kommet sterkere inn i programmet - ikke minst kommuner, fylkeskommuner, private aktører, non-profit organisasjoner etc. Et eksempel på fordelingen av prosjekter fordelt på institusjonstype er gitt i tabell 2.1.

Tabell 2.1. Institusjonstyper involvert i Nordplus Horisontal i 2009. Søknader.

\begin{tabular}{lrrr}
\hline Institusjon & Koordinator & Partner & Sum ant. inst. \\
\hline Høyere utdanning & 18 & 65 & 83 \\
Voksnes læring & 3 & 16 & 19 \\
Skoler & 1 & 35 & 36 \\
Offentlig og privat sektor & 13 & 44 & 57 \\
& 35 & 160 & 195 \\
\hline
\end{tabular}

Kilde: SiU (2010a).

Fordelingen i tabell 2.1 synes å indikere at Nordplus Horisontal har vært best kjent innen Høyere utdanning og innen andre aktører i offentlig og privat sektor, og der livslang læring og skolesektoren ikke i samme grad har vært involvert. Ikke minst tyder det høye antallet søkerinstitusjoner med koordinatoransvar innen Høyere utdanning på at initiativet til prosjektene ofte kommer herfra. Årsaken til at spesielt skolesektoren synes noe underrepresentert kan imidlertid også skyldes ressurssituasjonen, og kravet om 50 prosent egenfinansiering. Som en representant for en av medadministratorene for Horisontal uttrykte det:

Mange skoler har jo ikke budsjettmessig rom for å delta i denne type aktivitet når egenfinansieringsdelen er 50 prosent. På den andre siden gjør denne egenandelen at hvis de først er med så er de med på en veldig forpliktende måte. Eierskapet og engasjementet i prosjektet synes større.

Det er imidlertid nyanserte syn på denne problemstillingen, og både hos en del brukere og hos andre administratorer er det påpekt at egenandelene ikke nødvendigvis alltid betyr at man må stille opp med finansiering. Arbeidsinnsats eller andre typer bidrag kan også telle som egenandeler, men her har ikke alltid skolene den administrative kompetanse som skal til for å utnytte de frihetsgradene som tross alt eksisterer på dette feltet. Her kan man selvfølgelig også stille spørsmål ved om skolene har blitt tilstrekkelig informert om de mulighetene som tross alt er tilstede.

Ut fra at Nordplus Horisontal var et nytt program synes den geografiske spredningen i forhold til prosjektsøknader å være relativt god. At SIU er hovedadministrator for programmet kan kanskje forklare hvorfor Norge synes å være det land med flest søkere i en prosjektkoordinatorrolle i programmet. Tabell 2.2 gir et eksempel på geografisk fordeling i prosjektene i 2009. 
Tabell 2.2. Nordplus Horisontal: Antall prosjekter fordelt på institusjoner og land i 2009. Søkere.

\begin{tabular}{lrrr}
\hline Land & $\begin{array}{r}\text { Ant inst. som koordinerer } \\
\text { prosjekt }\end{array}$ & $\begin{array}{r}\text { Ant inst. som er partnere i } \\
\text { prosjekt }\end{array}$ & $\begin{array}{c}\text { Totalt ant. institusjoner } \\
\text { Norge }\end{array} \quad 9 \quad 24$ \\
Sverige & 6 & 28 & 33 \\
Danmark & 6 & 33 & 34 \\
Estland & 3 & 17 & 36 \\
Litauen & 3 & 13 & 20 \\
Latvia & 3 & 8 & 16 \\
Island & 3 & 8 & 11 \\
Grønnland & 2 & 2 & 11 \\
Finland & 0 & 26 & 4 \\
Færøyene & 0 & 1 & 26 \\
Åland & 0 & 0 & 1 \\
SUM & 35 & 160 & 0 \\
\hline
\end{tabular}

Kilde: SiU (2010a).

Som vist i tabellen er Danmark, Sverige og Norge de mest aktive søkerlandene i Horisontal, tett fulgt av Finland. Av de baltiske land er Estland mest aktivt, men både Latvia og Litauen er godt representert.

Tilbakemeldingene fra brukere av programmet er i hovedsak at Nordplus Horisontal er et veldig attraktivt program som er velegnet til å skape nye former for samarbeid og fornyelse innen tekningen om utdanning og læring.

Sett i forhold til målsettingene for Horisontal synes programmet i stor grad å oppfylle disse. Prosjektene som har fått støtte er i stor grad tverrsektorielle og har bidratt til å sette fokus på innovasjon og nytenkning i utdanning og læring. Sammenlignet med andre programmer som har en del historiske føringer knyttet til seg, fremstår Horisontal som et program som fanger opp aktører som ønsker å tenke nytt omkring utdanning og læring. Flere aktører påpeker at Horisontal synes å bryte ned skillene mellom forskning, utdanning og innovasjon, og at programmet slik sett er en mulighet for å konkretisere mer abstrakte politiske ideer om en sterkere integrasjon mellom disse områdene. 
Beste praksis, Polarforskning i klasserommet

Blant de aktiviteter Nordplus har støttet er prosjektet «Polarforskning i klasserommet» www.sarepta.org. Koordinert av Narom - Norsk senter for romrelatert opplæring gis lærere og lærestudenter en innføring i hvordan romrelatert forskning kan være relevant for undervisningsopplegg i skolen. Samarbeidende institusjoner omfatter læresteder innen Høyere utdanning og på lavere nivå i Danmark, på Island og i Norge, og hovedaktiviteten er å gi kompetansegivende (som gir 10 ECTS vekttall) kurs innen emner som «Klimaforskning i polare landskap»», «Under polarhimmelen (om Nordlys), og «Miljøendringer i sub-polare områder» gjennom en blanding av nettbasert undervisning og fysiske samlinger på Svalbard, på Island, etc. Prosjektet har etablert en egen blogg hvor resultater formidles og diskuteres.

Av tre grunner mener vi dette programmet kan stå som et eksempel på beste praksis.

\section{Programmets innhold}

- Prosjektet har en tydelig pedagogisk ide knyttet til hvordan forskning og forskere kan utnyttes både til mer allmenn formidling, men spesielt til undervisningsformål - på denne måten gir prosjektet innhold til begrep som «forskningsbasert undervisning» - også på lavere nivåer i skolen.

- Prosjektet skal avsluttes med en hjemmeeksamen som innholdsmessig skal munne ut i et pedagogisk opplegg for hvordan kunnskap ervervet gjennom prosjektet kan operasjonaliseres i egen undervisning.

- Prosjektet har et bevisst forhold til hvordan ny teknologi (GPS, datalogger) kan tas i bruk både som et arbeidsredskap i undervisning, og således medvirker prosjektet til å kople teknologi og pedagogikk.

Bruk av midler fra Nordplus-ordningen

- Midlene fra Nordplus er i hovedsak brukt til å medfinansiere konkrete samlinger på steder med stor relevans for prosjektet (Svalbard, Island, Andøya) - steder som ikke er enkelt tilgjengelige for mange.

Tilleggseffekter for Nordplus

- Kursene har så langt kun vært gitt på norsk, men vil fra 2011 også gis på engelsk bl a for å kunne inkludere deltakere fra de baltiske land.

\subsection{Samlet vurdering}

Nordplus Horisontal er det yngste programmet i Nordplus familien, og har sin opprinnelse i et ønske om å videreutvikle aktivitetene i Nordplus utover det fokus på mobilitet som tradisjonelt har kjennetegnet programmene. Selv om Horisontal har hatt en del innkjøringsproblemer knyttet til «hva programmet skal væ» - opplever både brukere og de som administrerer programmet at programmet over tid har fått en tydeligere profil. Sett i forhold til deltakelse fra de Baltiske land er Horisontal blant de mest vellykkede Nordplusprogrammene. Horisontal kan sies å ha oppfylt en av de sentrale 
målsettingene med programmet i og med at aktivitetene og prosjektene som er igangsatt vitner om en sterk orientering mot kvalitet og innovasjon.

Horisontal representerer på mange måter en nytenkning innen Nordplusamarbeidet, der prosjektene er noe større og deltakerne flere enn i andre programmer. Hvorvidt programmet faktisk har fått en tydelig profil synes likevel å være noe uavklart siden typer brukere har skiftet noe siden oppstarten. At programmet i starten også ble markedsført «ved siden av» de andre programmene kan også ha medvirket til at en del brukere har oppfattet Horisontal som en «reserveløsning», og ikke som et selvstendig program med en mer innovativ profil.

Hovedadministrator synes generelt at ressursrammene for Horisontal er relativt gode, og det synes i liten grad å være behov for å styrke ressursene. Samarbeidet mellom hoved- og medadministratorene synes også å være velfungerende, og brukerne opplever at programmet driftes på en god måte med god brukerstøtte. 



\section{Nordplus Høyere utdanning}

\subsection{Innledning}

Målt i antall søknader og i bevilgede midler er Nordplus Høyere utdanning over tid det største programmet i Nordplus familien. Programmet er spesielt rettet mot universiteter og høyskoler, og studenter og lærere ved disse institusjonene, men der dette i praksis betyr at individuelle søknader må gå gjennom den organisasjon vedkommende er tilknyttet.

Programmet var opprinnelig et rent mobilitetsprogram men aktiviteten er betraktelig utvidet i de siste programperioder. Ifølge håndboken for Nordplusprogrammene er viktige målsettinger for dette programmet å bidra til å etablere kontakt mellom Høyere utdanningsinstitusjoner gjennom utveksling av personer, praksis og resultater, samt å bedre kontakten mellom Høyere utdanning og andre aktører med interesse eller relevans for sektoren (Nordplus Handbook 2010: 24).

På bakgrunn av inkluderingen av de baltiske land i Nordplusamarbeidet har programmet i den senere tid prioritert å utvide eksisterende nettverk og prosjekter med tanke på nettopp å inkludere disse landene. Andre sentrale prioriteringer har vært å stimulere til felles studieprogrammer, samt prosjekter som omhandler kvalitetssikring.

I beskrivelsen av Nordplus Høyere utdanning heter det derfor at programmet i nåværende prosjektperiode skal bidra til:

- mobilitetsstipender for studenter og lærere, herunder såkalt ekspressmobilitet med varighet mindre enn en måned

- nettverksutvikling og -samarbeid

- prosjektutvikling herunder felles studieprogram eller nye studieplaner.

Profilen på Nordplus Høyere utdanning er ikke vesentlig endret fra forrige programperiode, og tiltak som eksempelvis felles studieprogram er således ikke nyskapninger fra inneværende programperiode. Generelt må prosjektsøknader til Høyere utdanning inkludere minst tre institusjoner i tre forskjellige land.

\subsection{Styringsstruktur og ressurser}

Nordplus Høyere utdanning er et svært etablert program i Nordplus familien, og har fordeler av det, ikke minst med tanke på profilering og publikums kjennskap til programmet. Ifølge hovedadministrator har programmets budsjett minsket i nåværende programperiode sammenlignet med den forrige 
perioden, fra ca 4.1 mill Euro i perioden 2004-2006, til ca 3.9 mill Euro i årene etter 2008. Samtidig er interessen for Nordplus Høyere utdanning er svært stor, og over tid har det totale søknadsbeløpet vært relativt stabilt i størrelsesorden 10 millioner Euro om året mens det faktiske budsjettet altså kun kun er på rundt 4 millioner Euro om året (CIMO 2010: 1). I de seneste årene har budsjettet tilsvart kun 20 prosent av det totale søknadsbeløpet, en ytterligere skjerpelse fra forrige programperiode (Vabø 2006: 26). Tradisjonelt har imidlertid Nordplus Høyere utdanning løst dette problemet ved at mobilitetssøknadene kuttes ned i omfang, men der mange fremdeles inkluderes av ordningen. Antallet innvilgende søknader knyttet til prosjekter er derimot mer selektert.

Tall viser at man innen Høyere utdanning i programperioden i gjennomsnitt har bevilget rundt 25 prosent av søknadsbeløpet som det søkes om (CIMO Applications and proposal for distribution of funds 2010: 1). Det kan anlegges ulike syn på denne problemstillingen: På den ene siden hevdes det at konkurransen om midler bidrar til høy kvalitet i programmet (prosjekter). På den andre siden hevdes det også at dagens tildelingsmønster - spesielt i forhold til mobilitet - i realiteten ikke signaliserer noen prioriteringer siden majoriteten av søkerne faktisk får tilslag.

Det forhold at mange får midler, men der man får færre ressurser enn det man har søkt om avstedkommer to typer reaksjoner blant brukerne. For det første synes flere brukere tradisjonelt å søke om langt mer enn det de reelt sett har brukt nettopp ut fra antakelsen om at søknader uansett blir kuttet. For det andre indikerer brukere at man etter hvert også bygger opp et tillitsforhold til hovedadministrator som bidrar til at søkere oppfattes som seriøse og ansvarlige noe som bidrar til at det er vanskelig å eliminere søkere. At man i de seneste årene har sett en utvikling i retning av mer realistiske søknadsbeløp, kan imidlertid tyde på at et slikt tillitsforhold også kan redusere tendensene til mer "strategisk» søkeadferd. Uansett er imidlertid mange søkere gjengangere, og et potensielt problem i Nordplus Høyere utdanning er dermed hvordan man kan få til fornyelse når mange søkere nettopp vektlegger langsiktighet og kontinuitet. Som en av brukerne påpeker:

Vi har vært en del av Nordplus lenge, og vi føler vel også at Nordplus er en del av oss. Sånn sett føler vi heller ikke det store behovet for endring. Vi synes vi har et godt prosjekt som vi gjennomfører bra - så hvorfor skal vi endre på dette?

Ressursutnyttelsen i Nordplus Høyere utdanning synes likevel å ha vært noe varierende over tid ut fra at budsjettbeløpet ikke alltid har blitt fordelt ut. I 2009 ble eksempelvis 200.000 Euro returnert som ikke-disponerte midler (CIMO 2010: 1). Over tid har imidlertid færre midler stått udisponert ved årets utløp, og i 2010 synes situasjonen å være at det budsjetterte beløp er stipulert å brukes opp. I hovedsak skyldes ubrukte midler at ulike mobilitetsprosjekter likevel ikke ble gjennomført som planlagt. Dette indikerer at oppfølging av prosjektmidler i forhold til implementering er viktig for å bidra til en sunn økonomistyring i delprogrammet. 
Sett i et styringsperspektiv fungerer Nordplus Høyere utdanning godt. Det rapporteres fra begge hold at det løpende samarbeidet mellom hovedadministrator og programkomiteen er konstruktivt og preget av god dialog. CIMO har da også lang erfaring med Nordplus Høyere utdanning, og synes av andre administratorer å ha svært anerkjent kompetanse på feltet.

Samtidig råder det en viss usikkerhet knyttet til hvem som i realiteten har beslutningsmyndighet i den nåværende strukturen. Det forhold at ledelsen i programkomiteen går på omgang, og at det var vært vanskelig å hente ut gode analyser av prosjektene har bidratt til at programkomiteen ofte må ta informasjon til etterretning og i realiteten har blitt et mer «godkjenningsorgan» enn et «strategisk organ» der man i dialog med hovedadministrator også i større grad kan delta i planlegging og vurderinger knyttet til fremtidig aktiviteter.

Når det gjelder forholdet mellom hovedadministrator og Nordisk ministerråds sekretariat synes det å ha vært enkelte problem i oppstarten av den nye programperioden, igjen knyttet til hva slags beslutningsmyndighet ulike aktører har. Mens ministerrådets sekretariat har ansvaret for iverksetting av de politiske beslutninger som fattes, skal hovedadministrator og hovedkoordinator stå for gjennomføringen av disse. Samtidig synes de ulike aktørene å ha noe ulike oppfatninger av hva som faktisk er politiske og hva som er mer administrative spørsmål, men dette synes å ha gått seg til over tid. Typisk nok synes imidlertid klarleggingen av slike spørsmål å bli rettet direkte til sekretariatet i København, og ikke alltid til hovedkoordinator eller hovedadministrator. Dette skaper igjen uklarhet i styringsstrukturen, og at ulike aktører sitter med ulik informasjon bidrar heller ikke en optimal beslutningsprosess. At denne type situasjoner oppstår synes paradoksalt nok å være et resultat av at man i Nordplusprogrammet både opererer med lave tersker for henvendelser og besvarelser av disse, og fordi mange av aktørene kjenner hverandre svært godt. Et system som i prinsippet fungerer rimelig godt på det uformelle plan bidrar altså til å skape uklarheter i den formelle styringsstrukturen.

På spørsmål om inkluderingen av de Baltiske land har medført problemer i Nordplus Høyere utdanning er det enighet om at de tre nye landene i samarbeidet har tilført nye dimensjoner uten at dette har betydd spesielle utfordringer. Av 254 søknader i 2009 var læresteder fra de baltiske land koordinator i 11 nettverk, men deltok som partner i rundt 80 nettverk (ca 30 prosent) (CIMO 2009: 2). I 2010 har andelen koordinatorer fra de baltiske land økt til 20. Den baltiske integrasjonen i Høyere utdanning å likevel å være noe mindre en i de andre programmene i Nordplusfamilien.

Av problematiske forhold som nevnes er ressurssituasjonen kanskje mest prekær. Siden ressurssituasjonen i utgangspunktet er presset, har inntredenen av tre nye land ytterligere bidratt til en situasjon hvor ressursene er i ferd med å bli utilstrekkelige. Selv om totalrammen til Nordplus ble økt som en følge av baltisk deltakelse synes budsjettrammen til Høyere utdanning like- 
vel å være redusert sammenlignet med forrige programperiode. Som en representant for en av medadministratorene i programmet påpekte har:

Man jo et ressursproblem innen «Høyere utdanning»... Attraktivitet er avhengig av ressurser.

Av andre forhold knyttet til Baltiske deltakelse nevnes det at man har opplevd en del kulturforskjeller og ulike forvaltningstradisjoner knyttet til hvordan regler skal tolkes og prosedyrene for å gjøre dette. Her synes man også å ha funnet gode og pragmatiske løsninger over tid.

Det er delte oppfatninger både hos administratorer og hos brukere hvorvidt det er en fordel eller en ulempe at Nordplus Høyere utdanning har store likhetstrekk med tilsvarende mobilitetsprogrammer innen EU. Hos de som fremhever at Nordplus taper i konkurransen med mobilitetsprogrammene i EU er argumentene gjerne at ressursene er mindre i Nordplusprogrammet, noe som har en negativ innvirkning på konkurransesituasjonen siden mange nordiske universiteter og høyskoler også benytter EU programmene til utveksling innen Norden. Flere brukere hevder også at Nordplus Høyere utdanning er blitt mer «byråkratisk» enn det har vært, men der de innrømmer at programmet ikke er så formalistisk som EUs programmer.

Hos de som fremhever at Nordplus Høyere utdanning og EUs programmer styrker hverandre er argumentene at det er enklere å markedsføre og promotere programmene samlet, at programmene til dels henvender seg til litt ulike segmenter og nisjer, der det kan være lettere å initiere og drifte et prosjekt/mobilitet innen Norden enn å gjøre det i EU, og der resultatet er at Nordplus fungerer som en enklere «inngangsbillett» til internasjonalisering enn tilfellet er med EU-programmene. Ekspressmobilitet er også noe som fremheves som en sterk konkurransefordel i Nordplus - dette er ikke en mulighet i LLP programmene. Fra enkelte brukere påpekes det også at Nordplus Høyere utdanning på mange måter er den «gamle formen» for internasjonalisering i betydningen at det vitenskapelige personellet er tett koplet til prosjektene/mobiliteten. Hos mange brukere synes det som om integreringen av det vitenskapelige personellet ikke alltid er like sterk i EUs mobilitetsprogrammer.

Det antydes fra hovedadministrator at mulige grep kan være å gjøre det lettere å søke Nordplus Høyere utdanning, der enklere søknadsprosedyrer kan gi en styrket konkurransefordel. Samtidig påpekes det fra søkerne selv at Nordplus Høyere utdanning har den største konkurransefordelen i den fleksibilitet som er resultatet av (historisk) kjennskap til ulike aktører i Nordplus, til ulike nettverk, til lave terskler for å ta kontakt for å finne løsninger.

\subsection{Administrasjon og drift av programmet}

Modellen med hovedadministrator og medadministratorer får generelt stor oppslutning, og det hevdes at denne organiseringen utgjør en svært hensikt- 
messig driftsform. Ulike informanter bekrefter at medadministratorrollen er viktig ut fra at den gir et kontaktpunkt i det enkelte land, og der potensielle søkere alltid har stor nærhet til en som kan svare på spørsmål om alle programmene i Nordplusfamilien. At medadministratorene også deltar i søknadsbehandlingen bidrar i tillegg til at kunnskapen om programmene er god. Fra hovedadministrator hevdes det i tillegg at den nåværende modell også har lave terskler ved at eventuelle språkbarrierer minimeres ved at søkere alltid kan henvende seg til et kontor i eget land, og som behersker eget språk.

Av konkrete forbedringspunkter som nevnes er en enda større klarhet i regler slik at unødig kontakt med hovedadministrator kan minimeres. Det anføres også at beslutningsprosessene noen ganger kan trekke for mye ut $\mathrm{i}$ tid som en følge av kravet om delaktighet og medansvar.

Et spesielt problem for Nordplus Høyere utdanning er at man på grunn av det høye antallet søknader blir svært presset når det gjelder saksbehandlingstid. Dette programmet har (sammen med Junior) det høyeste antall søkere (rundt 250 per år), men opererer med samme saksbehandlingstid som de andre programmene som generelt har et betydelig mindre antall søknader.

Ser man på fordelingen av ressursene i forhold til ulike aktiviteter er generelt mobilitet fremdeles den største aktiviteten målt i allokerte midler. Rundt 70 prosent av ressursene avsettes til mobilitet, mens de resterende ble brukt til andre prosjekter. Samtidig har majoriteten av mobilitetsprosjektene også andre aktiviteter tilknyttet.

Som nevnt innledningsvis i denne rapporten har ARS vært en utfordring for alle delprogrammene i Nordplus - herunder Nordplus Høyere utdanning. En bruker sier dette så sterkt at:

Når ARS ble lansert var det jo et totalkrasj i systemet, og det var jo kun takket være at man hadde gode og etablerte kontakter og nettverk i Nordplusystemet som gjorde at det gikk bra. Sett i ettertid er det ikke noen tvil om systemet har skadet omdømmet til Nordplus. Heldigvis er det blitt bedre.

Samtidig er ikke ARS helt friskmeldt. Generelt synes man å ha tre typer problemer innen dette delprogrammet: For det første synes ARS i liten grad å være tilpasset programmet Høyere utdanning der selve håndtering av mobilitet, nettverk, etc. er vanskelig i ARS siden programvaren er bygd opp rundt enkeltprosjekt. For det andre er rapporterings- og statistikkverktøyet i ARS lite hensiktsmessig - både ved at de data som det rapporteres om i liten grad synes relevante for Nordplus, og fordi ARS er vanskelig å bruke. Av ting som nevnes spesielt er at man savner brukerhåndbøker, at oppsettene er ulogiske etc. For det tredje oppleves ARS som et verktøy som i liten grad kan brukes til å utvikle Høyere utdanning. Et argument her er at historisk statistikk og historiske data er vanskelig å trekke ut av systemet, og at man dermed vet lite om utviklingen over tid. Samtidig har det skjedd en positiv utvikling de seneste årene, og i dag fungerer ARS i alle fall rent teknisk for både brukere og hoved- og medadministratorer når det gjelder søknader, administrasjon av søknadene, samt at man også får ut enklere standardrapporter. 


\subsection{Profilering, spredning og informasjonsarbeid}

Siden Nordplus Høyere utdanning er et etablert og svært profilert program i Nordisk målestokk er kjennskapen til programmet blant utdanningsinstitusjonene svært god. Det påstås fra hovedadministrator at nærmest alle universitet og høyskoler i Norden deltar i programmet. På spørsmål til en bruker om hva slags profil programmet har, understrekes det at mange nok baserer sin oppfatning på historikken til Nordplus som et rent mobilitetsprogram, noe som ikke lenger er helt dekkende for Høyere utdanning. Vedkommende påpeker videre at:

Profilering er vel vanskelig fordi Høyere utdanning på mange måter er så fragmentert, helheten er ikke lett å få øye på. Websiden fungerer jo godt og er attraktiv, men oppdateringen av den kunne være langt bedre. Det skjer jo ikke mye der.

Det siste poenget understrekes også av hovedadministrator og hovedkoordinator som hevder at grunnet tidspress knyttet til administrasjon og drift er det svært begrenset tid som er til overs til formidling og spredning av resultater.

Når man skal prioritere mellom de oppgaver man er pålagt i konsortiet, synes nettopp profilering, spredning og informasjonsarbeid å være det som lettest nedprioriteres. Samtidig er man i prinsippet enig i at Nordplus Høyere utdanning bare kan styrkes gjennom at de vellykkede prosjektene blir kjent i det nordiske rom. Både brukere og administratorer er således enige om at web-siden slik den fungerer i dag mer er en ren informasjonsside enn en web-side for interaksjon.

\subsection{Måloppnåelse og resultater}

Antall søkere til Nordplus Høyere utdanning har de seneste årene sunket fra ca 300 til 250 uten at dette er ansett for å være spesielt problematisk all den tid ressursene man rår over er langt mindre enn søknadsbeløpet. Strategien knyttet til inkluderingen av de Baltiske land har vært å få institusjoner i de baltiske land med i eksisterende og veletablerte nettverk. Indikasjonene så langt er imidlertid at man ikke har lykkes godt nok med integreringen av de Baltiske land. Samtidig påpekes det fra hovedadministrator at baltiske universiteter og høyskoler i alle fall deltar i mer enn halvparten av alle søknader i programmet, og bevilgningene til nettverk der baltiske læresteder er med har også økt i de siste årene. I de prosjekter der de Baltiske land er med oppleves deres deltakelse som svært positiv.

Når det gjelder felles studieprogrammer, har det vært rundt 40 søknader om dette årlig hvorav rundt 10 er blitt innvilget - her synes altså nåløyet å være forholdsvis trangt sett i forhold til andre aktiviteter i programmet. I forhold til prosjekter som omhandler kvalitetssikring, har majoriteten av disse vært koplet til de felles studieprogrammene og suksessraten har dermed vært linket til nevnte fellesprogrammer. 
I 2010 ble 40 prosjekter blitt refusert i søknadsprosessen. I hovedsak refuseres disse ut fra at søknaden ikke tilfredsstiller krav om tydelige målsettinger og gjennomføring av disse, samt at enkelte også får avslag på grunn av dårlig resultatoppnåelse i forhold til tidligere prosjekt (CIMO Applications and proposal for distribution of funds 2010: 5). Hos brukere som har opplevd avslag på søknadene synes det imidlertid å være ønskelig med en tydeligere tilbakemelding om hva de konkrete årsakene er til at søknadene er blitt refusert. Enkelte brukere argumenterer her for at kravet om åpenhet $\mathrm{i}$ saksbehandling må gjelde begge veier, og at hvis krav om åpenhet og transparens stilles til brukere, må også tilsvarende krav til stilles til de som administrerer programmet.

Antall utviklings- og fagprosjekter har økt over tid i Høyere utdanning - i tråd med føringene i programmet. Her synes ulike aktører likevel å ha noe forskjellig oppfatning av hva som faktisk er god måloppnåelse i Nordplus Høyere utdanning. Mens man enkelt kan finne aktører som argumenterer sterkt for at Høyere utdanning fortsatt bør være et mobilitetsprogram, er det heller ikke vanskelig å finne andre aktører som mener at mobilitet er gårsdagens internasjonalisering, og at man i sterkere grad må utvikle faglig samarbeid og fellesprosjekter der mobilitet bare er en del av den totale aktiviteten.

Ser man på faglig spredning er det god disiplinær spredning på prosjektene i Nordplus Høyere utdanning. De fagområder som utmerker seg som de mest aktive er medisin, (lærer-) utdanning, samfunnsvitenskap og humaniora i nevnte rekkefølge (CIMO Applications and proposal for distribution of funds 2010: 3). Matematikk, informatikk, språk, landsbruksfag, arkitektur og jus er blant de fagområder som utviser minst synlighet i delprogrammet.

I forhold til de årlige innholdsmessige prioriteringene i programmet er det relativt mange aktører - både brukere og administratorer som fremhever at miljø og klima har vært viktige og vellykkede satsinger. Samtidig er det også flere brukere som erkjenner at man gjerne håndterer de årlige prioriteringer mest på et «symbolsk plan» - man skriver det inn i eksisterende søknader uten at man kanskje har gjennomført de store endringer i prosjektene som foreslås. Som en av brukerne hevder:

De årlige prioriteringene gjør i alle fall at vi blir mer kreative som søkere til programmet. Sett i forhold til vektleggingen på klima er det jo mye som kan falle inn under en slik merkelapp, så hvis prioriteringene er såpass generelle er det jo ikke vanskelig å tilpasse seg. 
Beste praksis - Kunsthøyskoleutdanninger i Norden

Blant de mange aktiviteter Nordplus har støttet er prosjektet «Kunsthøyskoleutdanninger i Norden» www.kuno.no. Dette er et nettverk som omfatter 16 nordiske og baltiske kunstakademier hvor ambisjonen er å utvikle et kunstakademi «uten vegger». Prosjektet omfatter ulike aktiviteter fra tradisjonell og ekspressmobilitet for studenter og lærere til etablering av et felles master program (Nordic Sound Art) med ti studenter. I tillegg har prosjektet etablert en egen blogg, og gjennomfører jevnlig ulike symposier hvor både lærere og studenter deltar, og hvor resultater formidles og diskuteres løpende via nevnte blogg.

Av tre grunner mener vi dette programmet kan stå som et eksempel på beste praksis.

Programmets innhold

- Prosjektet har en bevisst holdning til hvordan ulike typer aktiviteter kan inngå i et større hele. Prosjektdesignet bidrar til å skape både fleksibilitet samtidig som helheten bevares.

- Prosjektet demonstrerer hvordan mindre fagområder kan utvikle aktiviteter som man på egen hånd ikke ville ha klart å løfte (eget masterprogram).

- Viser på en utmerket måte hvordan ny teknologi kan utvikles og tas i bruk både som et arbeidsredskap for prosjektet, men og som spredning av informasjon om og profilering av prosjektet.

Bruk av midler fra Nordplus-ordningen

- I tillegg til midlene som mottas fra Nordplus til drift har prosjektet opprettet et eget sekretariat - basert på medlemsavgift fra deltakende læresteder - som sikrer større grad av profesjonalisering og koordinering av prosjektet.

Tilleggseffekter for Nordplus

- Prosjektet var opprinnelig ment som et rent mobilitets- og erfaringsutvekslingsprosjekt, men har over tid etablert nye samarbeidsaktiviteter som kvalitativt sett har endret prosjektets innhold mer i retning av de prioriteringer som Nordplus har definert for nåværende programperiode.

- Organiseringen av prosjektet, samt bruken av teknologi til å spre informasjon og resultater burde være til inspirasjon for andre prosjekter i Nordplus familien.

Mer generelt synes likevel enigheten å være stor om at Høyere utdanning er en suksess ut fra at programmet har pågått i mange år - med der interessen fremdeles er høy. Den store majoriteten av prosjektene har forløpt i henhold til innsendte planer, og kun 3 prosjekter synes ikke å ha blitt gjennomført. Flere påpeker at kontinuitet og at det er interesse for programmet er en viktig indikator på at dette er vellykket. Samtidig synes man også å se at programmet er i ferd med å endre seg. Den ordinære studentmobiliteten er blitt redusert de senere år, og ekspressmobiliteten (under 1 måned) øker markant i omfang (CIMO 2009: 6). 
Formaliseringen av Nordplusprogrammene har i tillegg bidratt til at brukerne følges tettere opp enn før, ikke minst i forhold til rapportering. Fordi det tydeligvis har skjedd en innskjerpelse på dette området synes det som om dette er en av årsakene til at flere brukere rapporterer om at Nordplus er mer «byråkratisk» enn før. Flere brukere synes også å slite med å rapportere mer innholdsmessig om hva de har klart å få til i sine prosjekter. Generelt synes de fleste brukere å henvise til sine hjemmesider som formidlingskanal, og prosjektene synes også å resultere i produkter så som web-baserte kurser og kursmateriell, samt bøker og artikler (CIMO 2009: 9). Mange brukere synes imidlertid resultatformidling er en utfordring. Som en bruker understreker:

Problemet er at vi jo ikke kan dokumentere måloppnåelsen - det sosiale og kulturelle aspektet - på en kvantitativ måte.

Mange brukere understreker at de innholdsmessige effektene av Høyere utdanning er uformelle, langsiktige og svært vanskelig å måle. Mange synes å oppgi resultater i antall rapporter, konferanser, utviklingsprosesser, oversettelser eller annet, men de erkjenner at slike produkter neppe gir et veldig godt bilde av hvilke resultater som er oppnådd knyttet til kunnskapsutvikling og spredning. Slike indikatorer tilkjennegir mer at betingelsene for måloppnåelse i allefall er til stede.

\subsection{Samlet vurdering}

Nordplus Høyere utdanning er det største og mest etablerte programmet i Nordplus familien. Gitt den lange innkjøringstiden programmet har hatt i Norden er hovedinntrykket at programmet i store trekk er velfungerende. Hovedadministrator synes å være en effektiv drifter av programmet, og styringen og administrasjonen av programmet synes å skje profesjonelt og med lave terskler overfor brukerne. Programperioden sett under ett er imidlertid den administrative resultatformidling og analysene noe mangelfulle, men dette har stor sammenheng med innføringen av ARS. Her synes det imidlertid å ha skjedd en positiv utvikling de senere årene - ikke minst opplever brukerne at ARS i dag har et velfungerende brukergrensesnitt.

Samtidig er det også mulig å argumentere for at Nordplus Høyere utdanning etter hvert har blitt et så etablert form for samarbeid for en del av nettverkene at støtten fra Nordplus mer tenkes på som «drift» enn som insentiver for å skape merverdi - spesielt i forhold til mobilitet. Mange brukerne rapporterer da også selv at mange av aktivitetene i delprogrammet faktisk ville skje uten finansiell støtte fra programmet (CIMO 2009: 11). At antall søknader og at søknadsbeløpet likevel er så høyt som det er, kan tyde på at mange av brukerne søker av «gammel vane» og ut fra tradisjon, igjen et forhold som er tett knyttet til mobilitet. Mobilitet er uten tvil fremdeles en svært sentral form for internasjonalisering og kunnskapsutveksling i Norden, 
men spørsmålet fremover er om dette for all tid skal være den sentrale metoden i Nordplus Høyere utdanning, eller om dette i større grad er en ansvar for kan overlates til andre?

Det er derfor mulig å argumentere for at tiden kan være moden for å tenke mer nytt omkring hva Nordplus Høyere utdanning skal være i årene som kommer. Flere brukere og også flere administratorer ser både samspillsgevinster og ulemper i forhold til EUs LLP programmer, og sitatet fra en bruker kan stå som en indikasjon på disse tankene:

Man trenger å tenke nytt omkring Nordplus Høyere utdanning. Mobilitet representerer en veldig tradisjonell tenkning - vi trenger nytenkning!

Mange brukere og informanter ser helst at Nordplus både bør ivareta det tradisjonelle mobilitetsansvaret, samtidig med at man i større grad initierer nyskapende prosjekter innen Høyere utdanning som har et bredere virkemiddelsett enn bare mobilitet. Her synes dagens ressursrammer likevel å sette en stopper for et slikt ønske, og det innebærer at man kanskje i årene fremover bør ha en tydeligere profil knyttet til Nordplus Høyere utdanning. I kapittel 9 drøftes dette forholdet nærmere. 


\section{Nordplus Junior}

\subsection{Innledning}

Forgjengeren for Nordplus Junior, Nordplus Mini, ble organisert av Foreningen Norden, og hovedaktiviteten var mobilitet i form av skoleklasseutveksling. Da denne aktiviteten ble innlemmet i Nordplus rammeprogram i den forrige programperioden, var det innenfor et Nordplus Junior der formålet var å styrke den nordiske dimensjonen gjennom skolesamarbeid mellom de nordiske landene. Samarbeidet skulle bidra til å øke kunnskapen og forståelsen for andre nordiske kulturer, språk og livsvilkår, og også bidra til å fremme den nordiske samhørigheten hva gjelder nordiske verdier, menneske- og demokratisyn (Vabø 2006: 31). De første årene etter at Nordplus Junior ble etablert i 2004, var i følge Vabø (2006) preget av en viss utprøving av mulighetene i programmet. For programperioden som evalueres her (2008-2011), er formålet for Nordplus Junior mer sektorrettet: «(...) å styrke og utvikle samarbeidet og skape nettverk av førskoler, grunnskoler og videregående skoler (studieforberedende og yrkesforberedende) blant de deltagende landene for å støtte utviklingen av kvalitet og fornyelse» (Nordplus 2008-2011, Håndbok 2010: 17). Organisasjoner eller institusjoner som arbeider med eller har sterke interesser innenfor grunnopplæringen kan også søke.

Virkemidlene i Junior har vært de samme i begge programperiodene, og disse er; mobilitet, utviklingsprosjekt og nettverk:

- Mobilitetssamarbeid krever minst to partnere i to land, og omfatter elever i grunnskole og videregående opplæring, samt lærere og øvrig pedagogisk personale innenfor førskole, grunnskole og videregående opplæring. Elevmobilitet kan gjelde klasser i grunnskole og videregående opplæring, samt mobilitet for enkeltelever i videregående opplæring. Mobilitetsdelen skal ha et tematisk innhold, og kan ha varighet fra en til tre uker i løpet av et år, mens det for elever i videregående opplæring er mulighet for å ha individuelle mobilitetsopphold i inntil ett år. Mobilitet for lærere og annet pedagogisk personal inkluderer job-switching mellom skoler i ulike land. Det gis bidrag til forberedende besøk.

- Utviklingsprosjekt skal ha fokus på å forbedre pedagogiske metoder, og skal være relatert til pedagogisk utviklingsarbeid innenfor de årlige prioriteringene i Nordplus. Innenfor rammen av yrkesopplæringen skal utviklingsprosjekter bidra til å øke kvaliteten i fagopplæringen. Det kan søkes av minst tre partnerskoler fra minst tre land. Prosjektaktiviteter 
kan pågå innenfor en tidsperiode på opptil tre år, og samarbeidet innebærer at prosjektene skal integreres i skolenes virksomhet.

- Nettverksstøtte bevilges til langsiktig samarbeid blant minst tre partnerskoler fra minst tre land, og kan også ha opptil tre års varighet Det ses på som positivt med samarbeid mellom utdanningsnivåene.

Støtte til mobilitet er bidragsbeløp basert på fastsatte satser for reise og opphold. Satsene varierer etter hvilke land reisene går mellom (Nordplus 20082011, Håndbok 2010: 20). Elever får kun støtte til reisen, og det er lagt opp til at elevene bor hos hverandre. Nytt i denne programperioden er at lærere og annet pedagogisk personell får støtte til opphold. Selv om det heter seg at søkeren ikke behøver å bidra med egenfinansiering for mobilitetsaktiviteten, er det muligheter for at de faste satsene ikke dekker alt, og at det er behov for egeninnsats. Det er også nytt i denne programperioden at uansett støtteform skal én skole være koordinator på vegne av de involverte, og med ansvar for søknaden og de bevilgede midlene i hele kontraktsperioden. Dette ble iverksatt for å lette på prosessen med å kople de tidligere individuelle søknadene, og var således et grep for å lette den administrative prosessen. For utviklingsprosjekt og nettverk kreves 50 prosent egenfinansiering av det totale budsjett, dette gjelder også planleggingsmøter og forberedende besøk. Egenfinansieringen kan enten være i form av skolens egen innsats i form av arbeidstid, eller annen medfinansiering. For utviklingsprosjekt gis administrativ støtte til på inntil 5 prosent av samlet søknadssum. Det kan også gis støtte til kontaktseminar.

Søknadsfristen for Junior-aktivitetene er 1. mars hvert år, mens det er søknadsfrist for støtte til forberedende besøk 15.oktober hvert år. Nye søkere prioriteres fremfor søkere som tidligere har fått bidrag fra programmet. Hovedadministrasjonen for Nordplus Junior har siden 2004 vært ved Internationella kontoret i Sverige.

\subsection{Styringsstruktur og ressurser}

Dagens organisasjonsmodell med hovedadministrator og medadministratoroppgaver for Nordplus Junior, synes å ha flere fordeler. Blant fordelene er særlig at hovedansvaret er tydelig plassert. Samarbeidet mellom landene når det gjelder vurderingene av søknadene fremheves også som en viktig fordel med nåværende organisering. Eierskapet til Nordplus-programmene styrkes av at hoved- og medadministratorene også har oppgaver i tilknytning til administrasjon av andre Nordplus-programmer.

Av ulemper med dagens organisering nevnes at det er tidkrevende beslutningsprosesser, og at endringer tar tid. Ansvars- og oppgavefordelingen mellom hovedadministrator, programkomiteen og NMRs sekretariet synes å være uklar. Dette kan bidra til å forklare at det er svært ulike oppfatninger om programmet blant aktørene på de ulike nivåene. Det nye med ramme- 
programmet for 2008-2011 er at det skal fokusere mer på resultater og være mer prosjektorientert enn forrige programperiode. Nordplus Junior er tilpasset dette, og således endret i forhold til tidligere der mobilitet var hovedaktiviteten. I inneværende programperiode er det fra NMR større forventinger til at aktivitetene skal bringe resultater tilbake til skolene, utdanningssystemene og politikken, noe som gjenspeiler at tiltak overfor barn og unge generelt har høy politisk oppmerksomhet.

Komitémedlemmene har den oppfatning at Junior-programmet fungerer bra, og at mobilitet fortsatt er et sentralt virkemiddel i programmet.

Utfordringene for Nordplus Junior synes å være knyttet programmets kompleksitet. Grunnopplæringen er underlagt bestemte organisatoriske og strukturelle vilkår som varierer de nordiske og baltiske landene i mellom. Programmet omfatter dessuten flere og svært ulike utdanningsnivåer, at barnehager og skoler er målgruppen, og at både barn, ungdom og voksne er brukere i programmet. Av spesielle utfordringer nevnes særlig det administrative og økonomiske regelverket og egenandelen.

Junior er i dag det nest største Nordplusprogrammet når det gjelder søkergrunnlaget, og det påpekes at det samtidig kanskje er de minst "profesjonelle» søkerne. Ofte er det enkeltlærere som tar initiativene, selv om det er skolene som er formelle partnere. Skolene som deltar er ofte institusjoner med knappe ressurser og mye bundet tid. I mobilitetsprogrammene er det en utfordring $\mathrm{i}$ forhold til kost og losji for elevene, da det ikke alltid er realistisk at de kan bo privat. For lærere og annet pedagogisk personal er det utfordringer knyttet til at satsene for reisestøtte noen ganger oppfattes som for lave i forhold til utgiftene, og for skolene at det kreves ressurser til vikar for lærere. Mulighetene for utviklingsprosjekt og nettverk er lite brukt, og fra flere hold påpekes det at dette kan skyldes egenandelskravet på 50 prosent, og de administrative ressursene oppfattes som knappe i forhold til oppgavene.

Tidsrammene for bruken av tildelte ressurser er også forholdsvis stramme. Det hevdes fra flere hold at sen søknadsfrist (1. mars hvert år) og sen tildeling (i mai/juni hvert år), kan gjøre det vanskelig for skolene å gjennomføre planene innenfor ett skoleår. Dette kan være en av årsakene til at en del av midlene ikke blir brukt opp. Det ble i forrige evaluering pekt på som et problem for skolene at de søker ett skoleår og må gjennomføre det neste året (Vabø 2006). Dette synes fortsatt å være et problem. I denne sammenhengen bør en derfor også vurdere hvorvidt det er hensiktsmessig for Nordplus Junior å ha søknadsfrist 1 . mars hvert år og at tildeling blir gjort kjent i mai. Forslag til løsning er at midlene i stedet kan brukes innenfor to skoleår, slik som i Comenius-programmet, og at det blir utbetalt en rundsum til hver skole i stedet for som nå, differensierte beløp.

Videre kan ulikhetene i eierstruktur for grunnopplæringen (grunnskole og videregående opplæring) i de nordiske og baltiske landene være en barriere. Særlig gjelder dette oppgaver knyttet til rapportering og regnskap. I denne sammenhengen etterlyses koordinatorer for internasjonalt arbeid på skoleeiernivå i tilknytning til Nordplus Junior. 


\subsection{Administrasjon og drift av programmet}

Driften og administrasjonen av Nordplus Junior synes å være utfordrende. Programmet som i utgangspunktet er komplekst, møter hindringer av byråkratisk og praktisk art, og her er ARS medvirkende. Kravet om at en skole skal være koordinator kom i siste programperiode, og representerte en standardisering og tilpasning til de øvrige i Nordplus av hensyn til ARS, der et viktig argument var å lette saksbehandlingen for administratorene. Dette har bidratt til en mer byråkratisk modell sett fra et brukerperspektiv. Av hensyn til brukergruppen for programmet, har det vært behov for å holde en lav brukerterskel og tett oppfølging, og dette synes (fortsatt) å ha ført til mye arbeid for hoved- og medadministratorene. I forhold til det elektroniske søknads- og rapporteringssystemet ARS rapporteres det om at det i 2010 ser ut til å fungere bedre enn de to tidligere år, men at ARS generelt oppfattes som en barriere for skolene i søkeprosessen. Et spesielt problem her er at det er lett å fylle ut feil felt i ARS, spesielt i budsjettdelen. Her synes det som om man kan ha noe å lære av søknadsutfyllingsprosessen i Comenius.

Samarbeidet mellom hovedadministrator og medadministrator i Nordplus Junior foregår i to årlige møter, begge på initiativ fra hovedadministrator. Ett informasjonsmøte før søknadsfristen 1 . mars der bedømmingsprosessen, poengsetting, kriterier og prioriteringer diskuteres og bestemmes. Deretter ett møte for å samordne bedømmingen som er gjort av søknadene. Resultatet samordnes av hovedadministrator og presenteres for programkomitéen (Årsberättelse 2009). Søknadsprosedyrene og driften av programmet er likevel preget av en viss usikkerhet som følge av uklarhetene om tolkning av Håndboken og regelverket. En revisjon av regelverket kan være et bidrag til å optimalisere ressursene i programmet. Dette vil også bidra til å redusere pågangen fra brukere angående små og store spørsmål som gjelder Nordplus Junior.

Brukerne oppfatter programmet som velfungerende, og de oppgir at de får god støtte og hjelp fra medadministrator og hovedadministrator. De oppgir at ARS er blitt mer brukervennlig, selv om det er forvirrende at man ikke blir geleidet til det som har relevans for Junior. Det påpekes at programmene har ulike målsettinger og praksis, og en felles tilpasning til samme mal i ARS er uheldig og passer dårlig for Junior- målgruppen. Brukerne har erfart at det er en fordel å ha søkt flere ganger, da kjenner de bedre hvordan man skal unngå «blindgatene» i ARS-systemet. Typisk utsagn er:

Det første året brukte jeg mye tid på å søke, men det fungerer bedre nå når jeg vet hvordan det skal brukes.

Til gjengjeld mener brukerne at det er mange uklarheter angående tildelingskriterier og tolkning av Håndboken. Kriteriet om at nye søkere får midler fremfor andre, er for eksempel lite kjent.

Fra hovedadministrator og medadministratorer påpekes det at uklarheter i skolesamarbeid om fordeling av penger blant partnerne, er et hinder i programmet. Dette gjelder særlig skolenes evne til å håndtere rollen som hen- 
holdsvis samarbeidspartnere og koordinator. Det rapporteres blant annet om at det for små skoler både i Norden og Baltikum kan være krevende å fungere som koordinator, og at det er en del bekymringer angående håndteringen av penger, for eksempel valutatransaksjoner.

I vurderingene av søknadene oppgir hovedadministrator at det brukes store ressurser på å gå gjennom søknadene for å finne ut hva søkerne planlegger å gjøre rent substansielt, og som er innenfor regelverket for programmet. Dette har blant annet sammenheng med at søkerne ikke får feilmelding i ARS om de fyller ut feil poster. Likeledes går det store ressurser til å stramme inn budsjettene på detaljnivå i søknadene. Dette har delvis sammenheng med uklarheter i regelverket, dels med at søkerne ikke får feilmelding i ARS når de fyller ut feil poster. I tillegg kommer at budsjettet $\mathrm{i}$ alle tildelinger beskjæres for å kunne dele ut til flere. Forslag til løsninger fra hovedadministrator og medadminstratorer er at Nordplus Junior forenkles og at det utvikles et klarere regelverk. I tillegg til klarere regelverk blir det foreslått å sette et tak for enkelttildelingene slik at søkerne kjenner de økonomiske rammene når de lager søknader.

\subsection{Profilering, spredning og informasjonsarbeid}

Den felles nettportal og grafiske profil for Nordplus ble utviklet for å være en styrke og bidra til profilering og spredning av informasjon om programmet. I følge NMR brukes ikke de disponible midlene til dette arbeidet opp hvert år. Hovedadministrator og medadministratorer oppgir at oppgavene knyttet til brukerkontakt og til behandling av søknadene på grunn av ARS tar mesteparten av tiden. Brukerne på sin side oppgir at det å være gjentatt bruker er en stor fordel for å forstå hva Junior går ut på. Ressursene til profilering og styrking av Nordplus Junior kan på denne bakgrunn vurderes mer tilrettelagt for denne spesielle gruppen brukere. For eksempel etterlyser brukerne kontaktmøter og søkerseminarer i programmet. Dette kan fremover utgjøre et prioritert virkemiddel i sprednings- og informasjonsarbeidet.

Det påpekes både av administratorer og brukere at det er behov for å gjøre Nordplus mer attraktivt for målgruppen, sammenlignet med for eksempel EUs Comenius-program. Et forslag er å tydeliggjøre den nordiske dimensjonen i Nordplus Junior gjennom Håndbok, regelverk og satsningsområder. Et annet virkemiddel er å forenkle Nordplus Junior. Det fremheves at det $\mathrm{i}$ Comenius er enklere å få informasjon, enklere søknads- og rapporteringssystemer, at prosjektstøtten er større og at tildelingene går over to år i stedet for ett. Her har de gjort en stor innsats i SIU med å forenkle og avbyråkratisere Comenius, og det skulle derfor være en mulighet for at SIU kan representere et spesielt ressursmiljø for et slikt arbeid. 


\subsection{Måloppnåelse og resultater}

Totalt søknadsbeløp i 2009 var 3850084 Euro, mens tildelte midler var 2084527 Euro.

Det totale antallet søknader til fristen i 2009 var 195, mens det i 2008 kom inn 340 søknader. I 2010 var antallet søkere 200 - en stabilisering i forhold til 2009. Det var en økning i søknader til Nordplus Junior fra 2007 til 2008, men deretter har det vært en nedgang, dette gjelder selv når det er tatt hensyn til at endringene i antall søknader gjenspeiler at det er krav om en koordinator som søker for alle involverte parter, og ikke som tidligere at alle søker separat. Nedgangen har likevel ikke medført en nedgang $i$ antall deltakere i prosjektene - tvert om har det her vært en økning fordi en koordinator i dag gjerne søker for et større antall deltakere. De prioriterte områder og tema for Nordplus Junior i perioden 2008-2011 er:

- Kvalitet i utdanning

- Yrkesutdanning

- Helse

- Forebygging av frafall

- Entreprenørskap

- Det multikulturelle klasserommet

- Klima

I de to første årene har flest søknader valgt «kvalitet i utdanningen“ som tema, deretter kommer «klima» som et hyppig valgt tema, mens temaet «forebygging av frafall» har lavest antall søknader. Mobilitet i form av klasseutveksling er den mest søkte aktiviteten, og videregående opplæring har flest søknader. Det er svært få søknader fra barnehager. Av de 40 søknadene for forberedende besøk som kom inn til fristen 15. oktober, ble det innvilget støtte til 33 (Årsberättelse 2009). Innenfor mobilitetsdelen av programmet er hovedaktiviteten utveksling av skoleklasser, mens til sammen 43 lærere/annet pedagogisk personell og elever har vært i individuell utveksling i løpet av 2009. Som det fremgår av tabell 4.1 under er det svært få nettverk og utviklingsprosjekter i Nordplus Junior. Flere av våre informanter påpeker at dette muligens kan ha sammenheng med egenandelen på 50 prosent $\mathrm{i}$ denne typen støtte.

Tabell 4.1. Nordplus Junior: Typer aktiviteter søkt og tildelt 2009. Antall

\begin{tabular}{llrr}
\hline Type aktivitet & & Antall aktiviteter søkt & Antall aktiviteter tildelt \\
\hline Mobilitet & Forberedende besøk & 24 & 17 \\
& Klasse-utveksling & 57 & 69 \\
& Utveksling av enkeltdeltagere & 113 & 43 \\
Tematisk nettverk & & 9 & 6 \\
Utviklingsprosjekt & & 6 & 4 \\
Total & & 209 & $139^{*}$ \\
\hline
\end{tabular}

*Totalt bevilgede var 135, men samlet blir det 139 aktiviteter. Dette skyldes at noen prosjekter har fått bevilgning til to ulike aktiviteter.

Kilde: Internationella kontoret, Sverige, Årsberättelse 2009. 
Tabell 4.2 under viser at hovedaktiviteten i Nordplus Junior foregår i grunnopplæringen. Videregående opplæring har flest tildelinger, og studieforberedende utdanningsprogram (gymnasieskolan) har noen flere tildelinger enn yrkesforberedende studieprogram (yrkesfag). Yrkesfaglig utdanning synes dermed å ha kommet mer med i Nordplus-sammenheng enn det som var tilfellet i forrige programperiode (Vabø 2006: 45). Derimot er søknadsgrunnlaget lite, og det er også få tildelinger til barnehager.

Tabell 4.2. Institusjonstyper involvert i Nordplus Junior 2009. Antall tildelt.

\begin{tabular}{|c|c|c|}
\hline Institusjon & Koordinator & Partner* \\
\hline Barnehage & 2 & \\
\hline Grunnskole & 55 & \\
\hline Videregående (studieforberedende/gymnasieskolan) & 39 & \\
\hline Videregående (yrkesforberedende studieprogram/yrkesfag) & 34 & \\
\hline Andre (stiftelser og for eksempel Foreningen Norden) & 5 & \\
\hline SUM & 135 & \\
\hline
\end{tabular}

* Statistikken er ikke mulig å få fram i ARS.

Kilde: Internationella kontoret, Sverige.

Tabell 4.3 under viser at Sverige og Finland er de mest aktive søkerlandene innenfor Nordplus Junior i 2009, tett fulgt av Danmark og Norge.

Tabell 4.3. Nordplus Junior: Antall mobilitet fordelt på institusjoner og land i 2009

\begin{tabular}{lrrr}
\hline Land & $\begin{array}{r}\text { Ant inst. som koordinerer } \\
\text { mobilitet }\end{array}$ & $\begin{array}{r}\text { Ant inst. som er } \\
\text { partnere }\end{array}$ & $\begin{array}{r}\text { Totalt ant. } \\
\text { Institusjoner }\end{array}$ \\
\hline Norge & 17 & 23 & 40 \\
Sverige & 27 & 40 & 67 \\
Danmark & 26 & 29 & 55 \\
Estland & 7 & 16 & 23 \\
Litauen & 9 & 14 & 23 \\
Latvia & 6 & 13 & 19 \\
Island & 3 & 21 & 24 \\
Grønland & 2 & 3 & 5 \\
Finland & 35 & 29 & 64 \\
Færøyene & 2 & 3 & 5 \\
Åland & 1 & 0 & 1 \\
SUM & 135 & 191 & 326 \\
\hline
\end{tabular}

Kilde: Internationella kontoret, Sverige, Årsberättelse 2009.

Et problem som hindrer skolene fra å søke om mobilitetsstøtte er den manglende fullfinansiering i og med at Nordplus Junior betaler reise for elever, men ikke kost og losji ut fra den tanke at elevene kan bo privat. Tidligere løste mange skoler dette gjennom innsamling av penger fra foreldrene, men i de nordiske landene er prinsippet om at den offentlige skolen er gratis nedfelt i lov, og foreldrebetaling er lovstridig. Skolene kan ikke samle inn penger, og foreldrene får ikke lov til å betale. Dette er i følge flere informanter et problem for mange skoler. 
Beste praksis - Biologisamarbeid mellom to videregående skoler fra Danmark og Island

Et eksempel på beste praksis illustrerer hvordan kravet til innhold i mobiliteten i Junior blir realisert, og man kan hevde at dette eksemplet i realiteten fungerer som et utviklingsprosjekt mellom to land. Prosjektet "Biologisamarbeid mellom to videregående skoler fra Danmark og Island» er et eksempel på hva som er gitt midler i Junior mobilitet (2008-2009). Den danske videregående skolen var koordinator, og lærerne hadde kompetanse i biologi og dansk. Innenfor temaet forurensning og global oppvarming har de to skoleklassene hver for seg arbeidet med temaet og gjort laboratorieeksperimenter. Hensikten har vært å undersøke elementene i økosystemet; produsenter (planter), konsumenter (dyr) og dekompositorer (for eksempel mikroorganismer) og søke å forklare hvordan de er koblet til hverandre og hvordan natur og mennesker påvirkes av forurensning og global oppvarming.

Det er også et kulturelement i prosjektet. Skoleklassene har besøkt hverandre på en ukes opphold, og det var lagt inn en dag med vanlig skole (biologiundervisning) i begge land, samt feltstudier og besøk til universitetsmiljøer. I Island omfattet besøket i tillegg besøk i naturreservater, båttur til Vestmannaislands inkludert fuglekikking og vandring på vulkan, besøk på steder som er sentrale i Islands historie, besøk på Biologisk institutt på universitetet i Island, etc. Besøket i København har tilsvarende vekt på historie, Islands historiske forbindelser til Danmark, samt på utveksling av faglig art mellom skoleklassene.

\section{Programmets innhold}

- Temaet er faglig aktuelt og forankret i læreplanen for studieforberedende program (gymnasieskolan) i videregående skole.

- Prosjektet har i tillegg til biologifaget et kulturelt fokus med vekt på menneskenes rolle og bruk av naturen i de to landene, og på likheter og forskjeller mellom landene i forståelse av forurensning etc. På denne måten er kultur og natur, og forskjellene i forutsetninger mellom landene tematisert.

- Elevene har fått besøke forskere i biologifaget på universitetsnivå.

- Det er lagt vekt på at elevene skal få kunnskap om likheter og forskjeller i arbeidsformer og rammevilkår i samme skoleslag og innenfor samme fag i to land.

- Elevene har gjennom hele skoleåret kommunisert med hverandre via Facebook.

Bruk av midler fra Nordplus-Junior

- Det er brukt satser fra Nordplus-mobilitet samt egeninnsats.

Tilleggseffekter for Nordplus

- Lærerne ønsket å bli kjent med andre måter å undervise på og rapporterer stort utbytte av mobiliteten med hensyn til nye ideer for egen undervisning.

- Den danske skoleklassen deltok i konkurransen «Unge Forskere», og vant en pris for sine bidrag i prosjektet.

- Koordinatoren var den første læreren på sin skole som søkte om Nordplusmidler, og har inspirert kolleger til å søke.

- Lokalavisen har brakt flere reportasjer om prosjektet 
Et annet problem som er påpekt er at det også er mobilitetsdel på grunnopplæringsområdet i Nordplus NSK, og at det er forskjellige krav til mobiliteten i de to programmene. Et typisk utsagn fra administratorene om dette er et:

Strukturen med fire Nordplus programmer i et rammeprogram og et femte utenfor rammeprogrammet er uhensiktsmessig og vanskelig å kommunisere til brukerne. I mobilitetsdel på grunnopplæringsområdet kan samme type aktivitet/samarbeidsform søkes i to forskjellige programmer. Det ville være en fordel om brukerne kun hadde ett program å forholde seg til, og at alle mulighetene for sektoren var samlet.

I mobilitetsdelen av Junior er det krav om redegjørelse for aktivitetene i forbindelse med mobiliteten, og dette skal være knyttet til de tematiske prioriteringene i programmet. Kravet om faglig innsats er brukerne inneforstått med. Et typisk utsagn blant brukerne er at:

I mobilitetsopphold i Junior må vi ha noe med oss, det skal være et faglig innhold.

Evalueringen av forrige programperiode tok opp at størstedelen av aktiviteten i Nordplus Junior syntes å være mobilitet, og det ble foreslått at det skulle legges større vekt på tematiske utviklingsprosjekter og på pedagogisk samarbeid for å utvikle og/eller utveksle undervisningsmateriell (Vabø 2006: 33). I denne programperioden er mulighetene for tematiske utviklingsprosjekter og nettverk hittil benyttet i liten grad. Blant informantene til denne evalueringen er det svært ulike oppfatninger om hva som er årsaken til dette, og dessuten i hvilken grad dette kan sies å være et problem.

På den ene side hevdes det at det må være kvalitet i samarbeidet, og at dette er bedre sikret i utviklingsprosjekter og nettverk enn i mobilitet. På den andre side hevdes det både av administratorene og brukere at det stilles forholdsvis strenge krav til planer og innhold i mobiliteten i Junior sammenlignet med kravene til mobilitet i flere av de øvrige programmene. Den viktigste forskjellen mellom disse aktivitetsformene i Nordplus Junior er imidlertid knyttet til elevenes rolle. I mobilitetsaktiviteten er elevene i sentrum, de er involvert i faglig aktivitet og får direkte erfaring med å møte jevnaldrende i andre land og samarbeide med dem. I utviklingsprosjekt vil det i større grad være de voksne, dvs. lærerne og skolene som er de sentrale aktørene, både i form av arbeids- og ressursinnsats (jf kravet om 50 prosent egenandel), og i form av at det i følge kriteriene for tildeling av midler skal resultere i forbedrede pedagogiske metoder. I utviklingsprosjekter blir elevene dermed $\mathrm{i}$ større grad studieobjekter for lærernes samarbeid og utprøving, enn deltagende aktører.

Det er både blant komitemedlemmer, administratorer og brukere påpekt at fysiske møter mellom barn og unge er utbytterikt for målgruppen og et sentralt virkemiddel i det nordiske samarbeidet som har språklig og kulturelt fellesskap på lengre sikt som formål. Et utsagn som er typisk for mange av de som er involvert i Junior er: 
For meg er mobiliteten det viktigste - å gi unge mulighet til å reise og møte andre som gruppe i andre land har en stor verdi i seg selv. En praktisk måte å få nabospråkforståelse, og en personlig og varig opplevelse for unge mennesker.

Det er på denne bakgrunn flere forhold som taler for at mobilitetsaktiviteter også i fremtiden bør ha en sentral plass i Nordplus rammeprogram for målgruppen barn og unge. Når det gjelder den lave oppslutningen om utviklingsprosjekter og tematiske nettverk, oppgis egenandelskravet som et problem, fordi skolenes tid er bundet opp med oppgaver knyttet til undervisningen og det derfor er lite rom for å legge inn arbeidstid som egeninnsats, og fordi skolenes budsjetter er stramme. Kravet til at det skal være tre skoler fra tre land involvert i utviklingsprosjekter kan også tenkes å være en hindring, da koordinatoroppgaven som nevnt oppfattes som krevende for skolene. Det kan derfor vurderes å redusere kravet til deltagende land som et ledd i øke bruken av denne delen av programmet. Noen få tildelinger i 2009 kombinerer flere aktivitetsformer. Om kravet i utviklingsprosjekter og tematiske nettverk reduseres til å gjelde to land, kan dette gi rom for flere aktivitetskombinasjoner.

Den lave aktiviteten blant barnehager i Nordplus Junior kan ha sammenheng med at det er utviklingsprosjekt og mobilitet blant personalet som er aktuelt. Mange av de samme hindringer som gjelder for grunnopplæringen vil også gjelde her, og kan være årsaken til den lave oppslutningen. Mye taler for at denne delen av programmet har liten relevans og bør tas ut.

\subsection{Samlet vurdering}

Nordplus Junior synes å være relevant og interessant for målgruppen, og brukerne er godt fornøyd. Målgruppene for programmet befinner seg innenfor en kompleks sektor, og søkerne er lite kompetente i forhold til et komplisert søknadssystem og regelverk. Det er ulike oppfatninger blant aktørene på de ulike nivåene innenfor Nordplus Junior om hvordan programmet fungerer i dag, og hva som er utfordringer framover.

Grunnopplæringen har lovpålagte arbeidsoppgaver og lite fleksibilitet tids- og ressursmessig. Dette stiller særlige krav til relevans av innretningen i Nordplus Junior sammenlignet med de øvrige programmene. Innenfor mobilitetsdelen er særlig manglende dekning av elevenes kost og losji etter hvert blitt et problem. Det samme gjelder satsene for reise og opphold for lærere og annet pedagogisk personell. Egenandelskravet i utviklingsprosjekter og tematiske nettverk synes å være en barriere for mange, samtidig som det også fungerer som en «kvalitetssikring» knyttet til interessen for prosjektet fra brukerne side. Det etterlyses flere kontakt- og søkeseminarer som kan bidra til rekruttering og opplæring av nye søkere. Det synes å være særlige behov i Nordplus Junior når det gjelder de nye søknads- og rapporteringsprosedyrene i programmet som er gjeldende fra 2008. Motsatt de øvrige programmene er det etterspurt en særlig plattform for Junior, som bidrar til 
forenkling av søknadsprosedyrene og som er koblet tett til regelverket for programmet.

Den lave aktiviteten blant barnehager i Nordplus Junior taler for at denne delen av programmet har liten relevans og bør tas ut.

Nordplus Junior har i denne programperioden hatt som formål å støtte utviklingen av kvalitet og fornyelse av grunnopplæringen, og er innrettet mot større aktivitet innenfor utviklingsprosjekt og tematiske nettverk. Likevel er hovedaktiviteten mobilitet, og det synes som om det er her interessen og motivasjonen for deltakelse er størst. Ut fra rammevilkårene i sektoren synes dette å være tydelige signaler om hva som oppfattes som faglig relevant og praktisk mulig. Sett i forhold til de overordnede målsettingene om nordisk nytte og nordisk samforståelse kan mobilitet for barn, unge og voksne i grunnopplæringen være et viktig virkemiddel og alternativ til for eksempel internettbasert kommunikasjon som etter hvert er blitt vanlig. Motsatt hva man forestilte seg for bare noen år tilbake, er det å legge til rette for personlige møter kanskje blitt viktigere som virkemiddel for å oppnå programmets målsettinger.

Forenkling av kravene når det gjelder utviklingsprosjekt og tematiske nettverk (fra tre land til to land), kan bidra til at disse aktivitetsformene enklere kan kombineres med mobilitetsaktiviteter enn det som er mulig innenfor gjeldende regelverk. En annen forenkling som kan tenkes er at mobilitetsstøtten kan bli mer fleksibel, slik at overskuddsmidler kan brukes til andre aktiviteter. I tillegg kan koordineringsrollen forenkles ved at den enkelte skole i større grad står ansvarlig for egne mobilitetskostnader. 



\section{Nordplus Voksen}

\subsection{Innledning}

Mange av de aktørene og typer aktiviteter som Nordplus Voksen er rettet mot fikk før 2004 regulær, årlig driftsbevilgning fra Nordisk ministerråd. Da Nordplus Voksen ble etablert som et nytt program i 2004, var formålet å forene voksenopplæring og folkeopplysning. Tanken var at ett program skulle samle både små og store aktører, profesjonelle og nykommere innenfor området voksnes læring. Samtidig ble en rekke permanente støtteordninger til drift av nordiske organisasjoner innenfor området lagt ned, og støtten til voksnes læring ble gjennom etableringen av Nordplus Voksen karakterisert som «en endring fra bistand til program» (Vabø 2006: 29). Nedslagsfeltet for programmet har således et sammensatt og mangfoldig preg.

Nordplus Voksen har i denne programperioden (2008-2011) til formål å styrke samarbeidet mellom aktører innenfor voksnes læring i de nordiske og baltiske land, og bidra til utvikling og fornyelse på området. Programmet skal bidra til å styrke og utvikle samarbeidet og skape nettverk og partnerskap mellom deltagerlandenes bidragsytere, og fremme utviklingen av kvalitet og innovasjon innenfor voksnes læring i deltagerlandene. Programmet skal stimulere og utvikle voksnes læring innenfor alle deler av voksnes læring, både formell, ikke-formell og uformell læring.

Mange typer aktører er aktuelle søkere for å delta i Nordplus Voksen:

Utdanningsinstitusjoner, organisasjoner, foreninger, næringsvirksomheter, NGO'er, biblioteker, museer og andre uformelle læringsarenaer, forskningsbaserte institusjoner med kompetanse og erfaring innenfor voksnes læring samt institusjoner som utdanner for undervisning og veiledning blant voksne. Programmet støtter mobilitet, prosjekter og nettverksaktiviteter:

- Mobilitet

I mobilitetsdelen av programmet kan det søkes støtte til forberedende besøk i forhold til de øvrige støtteformene, samt etter- og videreutdanningsopphold for undervisere og læringsansvarlige med minimum en ukes varighet, og med maksimum to deltagende personer per organisasjon eller institusjon. I denne delen av mobiliteten er det ikke krav om utveksling. Alle besøk i en mobilitetsavtale må foregå innenfor ett år.

Videre kan det søkes om utveksling av voksne elever og lærere/ kursholdere innenfor folkeopplysning og voksenundervisning, til tematiske nettverk, utviklingsprosjekter og kartleggingsprosjekter. Utvekslingsdelen har som formål å gi deltagerne ny profesjonell 
kompetanse og innsikt i andre kulturer, og kan ikke vare mindre enn fem dager på samme sted.

- Prosjektaktiviteter

Utviklingsprosjekter skal innebære utvikling av nye kurs/moduler, metoder etc. med formål å styrke voksnes læring, høyne kvaliteten eller imøtekomme nye læringsbehov. Det er krav om at prosjektene skal basere seg på tilgjengelig kunnskap, skal være produktorientert og kunne være tilgjengelig og anvendelig for andre utenfor prosjektet. Det skal foreligge en detaljert tidsplan over den planlagte aktiviteten. Forskningsbaserte institusjoner med erfaring og ekspertise innenfor voksnes læring kan inkluderes for å bidra til å styrke prosjektets resultater.

Kartleggingsprosjektene er forventet å bidra med ny kunnskap om voksnes læring gjennom å samle inn, avdekke og analysere eksisterende kunnskapsstatus og erfaringer, og disse prosjektene kan vare i inntil tre år. Det er et krav om at resultatene skal publiseres.

- Tematiske nettverk

Kravene til tematiske nettverk er at de bør bestå av en relativt bred gruppe organisasjoner, vanligvis flere enn fem. Minimum deltagelse for et nettverk er tre organisasjoner fra tre land, og med varighet på inntil tre år.

Selv om det heter seg at søkeren ikke behøver å bidra med egenfinansiering for mobilitetsaktivitetene, er det muligheter for at de faste satsene for reise og opphold i mobilitetssammenheng ikke dekker alt, og at det er behov for egeninnsats. Når det gjelder prosjekt- og nettverksaktiviteter er det den lavere medfinansieringsgraden på 25 prosent, (i motsetning til de øvrige programmers 50 prosent) som er grunnprinsippet. Tilskudd til prosjekt- og nettverksaktiviteter omfatter også støtte til reise, opphold og andre utgifter. Egenfinansieringen kan, i tillegg til kontante midler, bestå av arbeidstimer lagt ned i direkte tilknytning til Nordplus-prosjektet.

Prioriteringene i Nordplus Voksen er mange. I 2010 prioriteres voksnes basisferdigheter (dvs. lesing, skriving, regning og IKT) og språkferdigheter hos innvandrere og minoritetsgrupper i de nordiske og baltiske landene, samt andrespråksundervisning. Videre er satsningsområdene anerkjennelse og validering av realkompetanse, utfordringer i det moderne samfunn med særlig fokus på klima og miljø, styrket tilgjengelighet til kunnskap og utdannelse for alle, og samspill mellom firmaer og institusjoner med henblikk på etter- og videreutdanning for voksne. Nye søkere og partnerskap, nye emner eller problemstillinger eller nye metoder og løsningsmodeller samt søknader der det er samarbeid på tvers av organisasjoner og sektorer, prioriteres ved tildeling av midler. I tillegg har programmet også et sterkt fokus på svake grupper. Hovedadministrasjonen har siden 2004 ligget i Danmark. 


\subsection{Styringsstruktur og ressurser}

I Nordplus Voksen vurderes modellen med hovedadministrator og medadministrator som hensiktsmessig. Fordelene er blant annet at den sikrer at programmene får større synlighet i de enkelte landene, og at informasjon og veiledning blir gitt på søkernes eget språk. Typer aktører, forhold og rammevilkår er svært forskjellige i de ulike landene når det gjelder nedslagsfeltet for programmet. Kunnskap om de enkelte landenes særegne utdanningssystemer er derfor viktig i forbindelse med søkeprosessen og innstillingsarbeidet. Kommunikasjonen mellom hoved- og medadministratorene synes å være god, og er organisert gjennom halvårlige møter og ellers gjennom elektronisk kontakt.

Samarbeid og arbeidsdeling mellom nivåene synes å fungere godt på det konkrete, daglige plan. Den generelle usikkerhet som også rapporteres i andre programmer i forhold til hvilken rolle programadministrasjonen har i forhold til felleskonsortiet på den ene side og programkomité og hovedkomité på den andre side, blir også påpekt av mange av aktørene i Nordplus Voksen. Dette synes likevel ikke å ramme driften av programmet i særlig grad.

Nordplus Voksen dekker en sektor som i tillegg til å være sammensatt og lite homogen, av administratorer og komitémedlemmer også beskrives som et område med mange relativt små og ressurssvake organisasjoner og aktører. Arbeidet er preget av en generelt lav grad av profesjonalisering og derfor en betydelig avhengighet av enkeltpersoner, noe som skaper en viss sårbarhet og blant annet hevdes å ha bidratt til svingninger i søkermassen fra år til år.

Ressurssituasjonen er preget av at det kreves forholdsvis store ressurser til arbeid for å nå ut til målgruppene, og til veiledning i forhold til å utvikle gode søknader og bruk av ARS i søkeprosessen.

De baltiske landene synes å være godt integrert i Nordplus Voksen programmet både i administrasjonen og med hensyn til prosjektdeltagelse. De baltiske landenes deltagere i Nordplus Voksen er avhengige av at bevilgningen utbetales til avtalt tid. Mulige konsekvenser av økonomiske nedgangstider kan ikke spores i reduksjon i antallet søknader fra disse landene.

Det er et problem at ikke alle midlene blir brukt opp i budsjettåret som følge av terminering av prosjekter. Disse midlene blir flyttet til neste års tildeling, men problemet med ubrukte ressurser synes å være konstant. Et forslag til løsning er at det fra NMRs sekretariat etableres et garantifond slik at man kan tildele litt mer enn tildelte ressurser hvert år, og på denne måten ta høyde for å håndtere problemstillingen med ubrukte midler innenfor programperioden. Dette kan bidra til å sikre at de bevilgede midler kommer sektoren til gode. 


\subsection{Administrasjon og drift av programmet}

Samlet sett vurderes søknadsprosedyrene og driften av Nordplus Voksen å fungere godt. De to årlige søknadsfrister (1. mars for alle deler av programmet, 15. oktober for forberedende besøk) oppfattes som en god syklus som understøtter programmets formål og gir balanse i forhold til aktørenes behov når det gjelder de administrative ressurser. Det etterlyses imidlertid tidligere søknadsfrist på våren, for eksempel 1. februar. Når tildelingene skjer først i mai hvert år, kan dette oppfattes som for kort tid til å forberede aktiviteter ved oppstart av høstsemesteret i samme år i og med at all aktiviteten er knyttet til utdanning. Videre påpekes at egenfinansieringskravet kan utelukke visse deltagere i programmet, og at ressursene i prosjekter er små sammenlignet med tilsvarende program i EU.

Selv om samarbeidet mellom hoved- og medadministratorene beskrives som godt, synes det å være ulike tolkninger av regelverket for programmet. Det påpekes at det stilles strengere krav til søkerne innenfor Voksen enn i andre programmer (unntatt Junior der situasjonen hevdes å være den samme). En del uklarheter som det synes å være behov for å oppklare, er for det første hvorvidt utdanning skal kreves å være en del av utviklingsprosjektene eller ikke. En annen uklarhet er knyttet til hva som kan sies å være en mobilitetsaktivitet. En tredje uklarhet gjelder nettverk, som i dag hevdes å være noe annet $\mathrm{i}$ Voksen enn i de andre programmene, og fungerer som forberedelse til prosjekt. Det etterlyses en tydeligere beskrivelse av regelverket i Håndboken slik at søkere som ikke kan få penger, likevel blir godtatt i ARS som søkere.

I intervju med brukere av Nordplus Voksen kom det frem at to ulike aktører hadde helt forskjellige oppfatninger om hva som kreves for deltagelse i programmet. Dette kan indikere at det er ulike tolkninger blant brukerne og blant de som gir råd i forbindelse med søknadsprosessene. Det synes å være behov for en revisjon av Håndboken og en gjennomgang av hvordan programmets relevans oppfattes i landene (jfr synspunktene over om at programmet er for omfattende), og hvilke konsekvenser man bør trekke av dette for fremtidens programsatsninger.

Fra brukerne påpekes det at praksisen med at budsjettene blir skåret flatt ned med inntil 25-30 prosent, bør erstattes av klarere retningslinjer for hva som er taket på midlene man kan søke om. Det er et stort arbeid å skrive søknad, og da er det viktig å vite hva som er mulig. Det oppfattes også som et problem for kvaliteten i prosjektene at det gjøres flat beskjæring uten dialog med søkerne. Et typisk utsagn i denne forbindelse er at:

Det er viktig at de har tillit til oss, og budsjettene må vurderes ut fra om de er realistiske eller ikke. Enten må man gi penger, eller si nei til søknaden, ikke bare beskjære likt over alt.

Når det gjelder ARS har man i Nordplus Voksen tilsvarende synspunkter som i de øvrige programmene. For administrative formål må det lages skyggestatistikk utenom ARS, fordi ARS ikke skiller godt nok mellom søkte midler, 
tildelte midler og aktører. Selv om ARS i 2009 og 2010 har fungert uten vesentlige feil, viser erfaringene i følge administratorene at de også fremover kommer til å yte ganske omfattende hjelp til søkerne for at de skal forstå og kunne bruke systemet. De fleste aktører innenfor voksenopplærings- og folkeopplysningsområdet har lite erfaring med databaser og online systemer, og har derfor behov for assistanse i forbindelse med søknader og rapportering.

Det blir påpekt at ARS har medført endringer av programmets innhold, og at standardiseringen har ført til ensretting mellom programmene. Dette oppfattes som uheldig i forhold til de politiske prioriteringer og rammevilkårene som finnes i de sektorene programmene retter seg mot.

\subsection{Profilering, spredning og informasjonsarbeid}

Nordplus Voksen har en sammensatt målgruppe og dette gjenspeiles i mangfoldet av aktiviteter for å nå ut til aktuelle søkere. Det er arrangert et informasjonsmøte samt et skriveseminar i Danmark. Skriveseminaret ble arrangert for søkere fra alle de nordiske/baltiske landene, og hensikten var å gi råd om hvordan søkere kan planlegge sitt prosjekt og skrive best mulig søknader. Brukere og medadministratorer har oppgitt at dette har vært nyttig.

Det er dessuten spredd informasjon til danske målgrupper via elektronisk nyhetsbrev, og i tillegg gjøres mer målrettet informasjonsarbeid overfor målgruppen. Det rapporteres om synergi i forhold til internasjonale nettverk og at Nordplus programmene formidles parallelt med EU-programmene.

For å stimulere interessen for nordisk/baltisk samarbeid og for å få flere søknader til Nordplus Voksen programmet er det et ønske om å avholde kontaktseminarer på mer systematisk basis enn det gjøres i dag. Her bringes erfaringene fra EU-programmene fram som eksempel på hvordan dette kan gjøres mer systematisk enn hittil i Nordplus-sammenheng. Det påpekes at det er behov for øket ressursramme innenfor administrasjonsbidraget om dette skal kunne realiseres innenfor Nordplus Voksen.

Brukerne peker på at resultatene av utviklingsprosjektene er lite synlige for omverden. De ønsker at resultatformidling og erfaringsformidling prioriteres høyere i Nordplus Voksen, og foreslår for eksempel flere konferanser eller kontaktseminarer der resultater og erfaringer formidles til aktuelle aktører som ikke har vært involvert i prosjektene. Enkelte brukere nevner at Nettverk for Voksnes Læring (NVL) kan være viktig i forhold til spredning av resultater og kunnskap, og at Voksen i enda tettere grad kan utvikle et samarbeid med NVL om dette. 


\subsection{Måloppnåelse og resultater}

Totalt søknadsbeløp i perioden variert en del - fra nærmere 3,6 millioner Euro i 2008 til rundt 2,6 millioner Euro i 2009. I 2010 var søknadsbeløpet på rundt 3.2 millioner Euro.

Når det gjelder antall søknader har de i de siste årene også variert noe fra 90 i 2008, til henholdsvis 60 og 69 i 2009 og 2010.

Problemene knyttet til ARS i 2008 fremholdes som en forklaring på nedgangen i antall søkere fra 2008 til 2009, en annen er at søkertallet fra 2004 har variert en del mellom årene. Et tredje forhold som nevnes i årsrapporten er at de aktuelle søkerne har begrenset kapasitet, og derfor ikke søker hvert år. Dette synes å kunne forklare at det innen dette programmet er relativt stor variasjon når det gjelder søknader og søknasbeløp fra ett år til et annet.

Tabell 5.1 Godkjente søknader og bevillinger fordelt på land (som har koordinatoren)

\begin{tabular}{lrrrrrrr}
\hline & $\begin{array}{r}\mathbf{2 0 0 9} \\
\text { søknads- } \\
\text { runde 1 }\end{array}$ & Bevilget (€) & $\begin{array}{r}\text { 2009 } \\
\text { søknads- } \\
\text { runde 2 }\end{array}$ & Bevilget (€) & $\begin{array}{r}\text { I alt } \\
\text { antall }\end{array}$ & I alt bevilget & Andel (\%) \\
\hline Danmark & 8 & 292443 & 3 & 6800 & 11 & 299243 & $21 \% / 25 \%$ \\
Finland & 10 & 219099 & 2 & 3520 & 12 & 222619 & $23 \% / 18 \%$ \\
Island & 4 & 138764 & 0 & 0 & 4 & 138764 & $8 \% / 11 \%$ \\
Norge & 2 & 54161 & 1 & 4880 & 3 & 59041 & $6 \% / 5 \%$ \\
Sverige & 8 & 228795 & 3 & 9860 & 11 & 238655 & $21 \% / 20 \%$ \\
Estland & 3 & 71460 & 1 & 1360 & 4 & 72820 & $8 \% / 6 \%$ \\
Latvia & 3 & 75780 & 2 & 5170 & 5 & 80950 & $9 \% / 7 \%$ \\
Litauen & 2 & 94535 & 1 & 1080 & 3 & 95615 & $6 \% / 8 \%$ \\
Færøyene & 0 & 000 & 0 & 0 & 0 & 0 & $0 \% / 0 \%$ \\
Grønland & 0 & 000 & 0 & 0 & 0 & 0 & $0 \% / 0 \%$ \\
Åland & 0 & 000 & 0 & 0 & 0 & 0 & $0 \% / 0 \%$ \\
I alt & 40 & 1175037 & 13 & 32670 & 53 & 1207707 &
\end{tabular}

Kilde: Årsberetning 2009 til Nordisk ministerråd fra Styrelsen for International Uddannelse, Danmark.

Tabell 5.1 viser at det er god spredning på landene. Finland, Danmark og Sverige er de mest aktive søkerne, og er også de som lykkes best med tildelte midler. I forhold til folketallet har Sverige lavere deltagelse enn Finland og Danmark. Norge ligger lavt i andel søknader og deltagelse i forhold til folketallet. Island er blant de som lykkes godt, med deltagelse betydelig over befolkningsandelen.

De baltiske landene lykkes relativt godt og deltagelsen ligger på nivå med befolkningsandelen. For de selvstyrende områder er deltagelsen større enn det befolkningsandelen tilsier. Imidlertid tar disse landene sjelden i koordinatorrollen, og det er få deltagende organisasjoner.

Søknadene er i følge årsberetningen 2009 vurdert ut fra årets prioriteter, prosjektets formål og innhold, organisering og planer for implementering, og planer for spredning av resultater. Det er i tillegg stilt krav til en klar og tydelig søknad, at partnerskapene skal være relevante i forhold til prosjektet, og at det er et innovativt element. Ved tildelingene i 2009 har det i tillegg til disse kravene vært slik at nye søkere er prioritert, og søknader som har prosjekter på tvers av formell, uformell og ikke-formell voksenopplæring er foretrukket. Nordplus Voksen fremstår på denne bakgrunn som ambisiøs på 
vegne av målgruppen. På den ene side beskrives mange i målgruppen som ressurssvake og små, på den andre side legges det vekt på at det må stilles krav til feltet.

Samtidig praktiseres flat nedskjæring av søknadene som får tildeling, og dette begrunnes med at flere skal få, og fordi at en for lav suksessrate kan medføre at en del søkere ikke ville søke igjen. Dette «ostehøvelprinsippet» diskuteres i programkomitéen. Det synes å være en viss spenning i Voksen mellom den brede folkeopplysningen og den mer spesialiserte kunnskapsutviklingen. Det påpekes også av aktører at et mer overordnet problem for Nordplus Voksen er den manglende politiske interesse for og prioritering av feltet. Typisk utsagn er:

Hele folkeopplysningen hadde større innflytelse før. Dypest sett er det ikke mye fokus på voksnes læring i dag, alt fokus er på barn og unge. Men det blir trukket frem at de unge ikke får fullført sin utdannelse, men hvor skal de få utdanning om voksnes læring nedprioriteres?

Det blir også påpekt at det er disse organisasjonene som for eksempel ivaretar den formelle og mer uformelle læring blant innvandrere, og slike muligheter er særlig betydningsfulle for kvinnenes deltagelse i samfunnet, utenfor hjemmet.

Et spørsmål som det er ulike synspunkter på blant aktørene i programmet, er hvorvidt man skal videreutvikle og tilpasse programmet bedre for å imøtekomme de mange ulike behovene i en såpass sammensatt målgruppe, eller om man skal redusere ambisjonene for programmet og spisse innretningen mer.

Tabell 5.2 under viser bredden i institusjonstyper/organisasjoner som er tildelt midler i 2010. det fremgår av tabellen at aktører innenfor uformell læring etc. er svakt representert, mens organisasjoner og institusjoner som driver med formalisert læring, Høyere utdanning og forskning synes å være forholdsvis godt representert.

Tabell 5.2. Institusjonstyper/organisasjoner involvert i Nordplus Voksen 2010 - tildelte

\begin{tabular}{lrrr}
\hline Institusjonstypel organisasjoner & Koordinator & Partner & Sum ant inst. \\
\hline ActorsWithinInformalLearning & 0 & 1 & 1 \\
AdultEducationAssociation & 8 & 30 & 38 \\
CenterForAdultLearning & 11 & 25 & 36 \\
CentresForSpecialNeedsEducation & 1 & 6 & 7 \\
EmployersOrganization & 0 & 2 & 2 \\
EveningClassSchool & 0 & 1 & 1 \\
FolkHighSchool & 4 & 15 & 19 \\
LanguageSchool & 1 & 2 & 3 \\
OpenUniversity & 0 & 3 & 3 \\
Other & 5 & 19 & 24 \\
PrivateEnterprice & 4 & 9 & 13 \\
PublicEnterprise & 3 & 12 & 15 \\
ResearchCentre & 1 & 19 & 20 \\
SocialAndHealthSchool & 0 & 2 & 2 \\
TradeUnion & 1 & 3 & 4 \\
TrainingOpportunitiesScheme & 1 & 17 \\
Union & 0 & 14 & 2 \\
VocationalSchool1 & 3 & 0 & 218 \\
SUM & 2 & 174 & \\
\hline
\end{tabular}

Kilde: Danish Agency for International Education / Styrelsen for International Uddannelse. 
I følge egenevalueringene er det ulike syn innenfor administrasjonen av programmet om hvorvidt man fremover skal fokusere på mulighetene i programmet og å arbeide for å styrke bredden og mangfoldet, eller om spennvidden i Nordplus Voksen er blitt for stor. Brukerne tilslutter seg et synspunkt om at det er behov for en innstramming og tydeligere fokusering, og signaliserer at programmet i dag har fjernet seg mye fra den allmenne opplysningstanken og fokuset på erfaringsutveksling som tidligere ble forbundet med Nordplus Voksen. Typiske utsagn fra brukere illustrerer dette:

Profilen er god nok, men det er en overflødig barriere dette kravet om det tverrsektorielle.

Det vitenskapelige er et problem, det fyller mye i budsjettet og det koster å ha tilknyttet dem (forskere) om de skal gjøre et reelt arbeid. For oss ville erfaringsutveksling vært viktig.

Det er en hindring at det er en sterk output-fokusering i prosjektene. Man kunne spare penger om man var mer opptatt av erfaringsutveksling.

Forslag til løsninger er en tydeligere fokusering på noen innsatsområder, og at tematiske nettverk samt utviklingsprosjekter kunne dekke behovene for målgruppen. Det viktigste for Nordplus Voksen er i følge flere av aktørene det institusjonelle samarbeidet, og dette anses som å sikre mer varighet. Mobilitet blir av de samme ansett som mer individuelt, og derfor vanskeligere å få noe varig ut av. Det beskrives en motsetning mellom å spre kunnskap på institusjonelt nivå, og å gjøre individuelle erfaringer. Denne motsetningen bør diskuteres nærmere i programmet. 
Beste praksis - kultur som behandlingsform

Prosjektet «Kultur i värden - et utviklingsprojekt inom den nordiska äldreomsorgen» under Nordplus Voksen omhandler hvordan kulturelle aktiviteter kan stimulere og hjelpe eldre mennesker i deres hverdagsliv. Prosjektet har 11 deltagende organisasjoner fra Sverige, Norge og Finland. De involverte er forskjellige videreutdanningsinstitusjoner, høgskoler, kommuner og omsorgsinstitusjoner, og er koordinert av Yrkesakademin i Österbotten, enheten i Gamla Vasa, Finland. Prosjektet startet som ettårig nettverksprosjekt i 2006, og ble senere forlenget til et toårig utviklingsprosjekt. Formålet har vært å skape utdanningsmoduler om kulturelle aktiviteter i eldreomsorgen, og å etablere et langsiktig samarbeid mellom prosjektets partnere. Det er tre grunner til at vi mener programmet kan stå som et eksempel på beste praksis:

Programmets innhold

- Prosjektet benytter seg av kulturelle aktiviteter så som musikk, håndarbeid og litteratur for å stimulere hukommelsen blant de eldre.

- Deltagelsen i prosjektet gir partnerne mulighet for både å oppleve forskjellige kulturer og å utvikle undervisningsmoduler sammen.

- Gjennom samarbeidet i tre land utvikles en bred forståelse av kulturens muligheter i eldreomsorgen.

Bruk av midler fra Nordplus-ordningen

- Egenandel på 25 prosent er arbeidstimer som er lagt ned i prosjektet.

Tilleggseffekter for Nordplus

- Det er et eksempel på et nettverk kan brukes til å implementere kulturelle aktiviteter som en behandlingsform i eldreomsorgen.

- Det er utviklet et 40 timers kurs for etter- og videreutdanning innenfor helsefag på ulike nivåer.

- Resultatene er spredd gjennom rapport, radiointervju, avisoppslag, og på konferanse.

\subsection{Samlet vurdering}

Nordplus Voksen støtter mobilitet, prosjekter og nettverksaktiviteter. Nedslagsfeltet for programmet har et sammensatt og mangfoldig preg. Utdanning er nøkkelbegrep, og programmet skal stimulere og utvikle voksnes læring, både formell, ikke-formell og uformell læring. Mange typer aktører er aktuelle søkere for å delta i Nordplus Voksen.

Denne store bredden i Nordplus Voksen programmet kan synes å være en utfordring fremover. Det er få søkere innenfor uformell læring, og en stor del av aktørene som får midler er større formelle organisasjoner og institusjoner. Selv om egenandelskravet er redusert i Voksen sammenlignet med i de øvrige programmene, er dette likevel et kritisk punkt for deler av målgruppen, mens andre har ressurser til å dekke egenandelen. 
I og med at all aktiviteten er knyttet til utdanning på en eller annen måte, er naturlig oppstart av aktiviteter gjerne ved starten av høstsemesteret. Det etterlyses tidligere søknadsfrist på våren, for eksempel 1. februar, for å kunne tilpasse aktiviteten til dette. Når tildelingene skjer først i mai hvert år, kan dette være for kort tid til forberedelse.

Det synes å være ulike tolkninger av regelverket for programmet, og det hevdes å være strenge krav til søkerne innenfor Voksen. Det synes på denne bakgrunn å være behov for å gjennomgå programmet og tolkningsrommet $\mathrm{i}$ Håndboken,

Det er ulike synspunkter i programmet på hvorvidt man i programmet fremover skal arbeide for å styrke bredden og mangfoldet, eller at spennvidden i Nordplus Voksen er blitt for stor. Sett i forhold til målsettingene for programmet har Voksen i dag en profil som kan sies å oppfylle disse, og som i høy grad er tilpasset den nordiske tradisjon for mangfoldighet knyttet til voksenopplæringsområdet. Samtidig gir mange brukere uttrykk for at programmet trenger en tydeligere fokusering der de signaliserer at programmet i dag har fjernet seg fra den allmenne opplysningstanken. Visse aktører vurderer det institusjonelle samarbeidet som mer varig og som garantist for kvalitet, mens mobilitet blir ansett som mer individuelt og vanskeligere å få noe varig ut av. Motsetningen mellom å spre kunnskap på institusjonelt nivå, og å gjøre individuelle erfaringer bør diskuteres nærmere i programmet. 


\section{Nordplus nordisk språk og kultur}

\subsection{Innledning}

Språk og kultur er både et særskilt temaområde innenfor Nordplusordningen, men samtidig en gjennomgående og grunnleggende komponent ved det nordisk samarbeidet. De allmenne intensjonene bak et nordisk språk- og kulturprogram er knyttet til motiver som lå bak etableringen av et forpliktende nordisk samarbeid på statlig nivå etter andre verdenskrig. Samvirket var basert på en forståelse av et geografisk, historisk og språklig fellesskap i Norden. Formålet med samarbeidet var og er å bygge videre på dette fellesskapet og styrke samhørigheten i Norden gjennom tiltak både av materiell nytte og av instrumentell art, men også av mer immateriell karakter, slike som utveksling av kunnskap, gjensidig forståelse av hverandres språk og et bredt engasjement for nordiske kulturuttrykk og livsformer. Verdien av fellesskap i språk og kultur har stått sentralt i bevisstheten om å røkte og styrke økonomisk, sosial og kulturell samhørighet i Norden. Fellesskap og bestrebelser på å forstå hverandres morsmål, spesielt de skandinaviske nabospråkene, og kunne kommunisere med hverandre på skandinavisk, har vært et høyt prioritert område helt siden Nordisk råd ble grunnlagt i 1952. Det er slik sett et tradisjonsrikt felt dagens Nordplus nordisk språk og kultur (i teksten forkortet til språk og kultur eller NSK) viderefører. Nåværende program er også en fortsettelse av tidligere programmer med ganske like målsettinger, senest Nordplus språk.

Språk og kultur har organisatorisk en annen status enn de øvrige programmene i Nordplus-ordningen, det er formelt sett et separat program utenom de fire andre. Programmets virkefelt er språk i Norden; det omfatter foruten de tre skandinaviske språkene, også finsk og det samiske språkområdet, men ikke de baltiske språkene. Siden 2008 er landene i Baltikum innlemmet i Nordplus og deltar i alle andre programmer, men ikke dette. Mellom 2008 og 2011 er de overordnede formålene for språk og kultur:

- å styrke språkforståelse og spesielt nabospråkforståelse (dansk, svensk og norsk)

- å stimulere interessen for, kunnskapen om og forståelsen for nordiske kulturer, språk og livsvilkår (www.nordplusonline.org). 


\subsubsection{Avgrensning, språk i Norden - de nordiske språkene og de skandinaviske}

For å drøfte spørsmålet om språk- og kulturprogrammets profil og målsettinger trengs det kategorier som både klargjør språksituasjonen i Norden, og som kan danne grunnlag for å drøfte fremtidige satsinger innenfor området språk og kultur. Begrepet nordiske språk kan være synonymt med termen nordgermanske språk (norsk, dansk, svensk, islandsk og færøysk), eller nordiske språk kan bety de språkene som tales innenfor et geografisk område Norden. Da inngår foruten de tre skandinaviske språkene, dansk, svensk og norsk, og de øvrige nordgermanske, islandsk og færøysk, også språk i andre språkfamilier. I øvrig Nordplus-sammenheng er Baltikum inkludert i den geografiske betegnelsen Norden; slik sett kunne også nasjonalspråkene og andre språk i de baltiske landene tenkes føyd til listen ovenfor. I evalueringen av NSK vil nordiske språk bestemmes som språk som tales i Norden ekskludert Baltikum, mens skandinaviske språk defineres som nasjonalspråkene i Danmark, Sverige og Norge.

\subsection{Styringsstruktur og ressurser}

\subsubsection{NSK og Nordisk ministerråd}

Selv om NSK er et selvstendig program, er det organisatorisk assosiert til ordningen og integrert i Nordisk ministerråds styring og administrasjon av Nordplus.

I håndboken er språk og kultur omtalt på lik linje med øvrige programmer, det har samme hovedsøknadsfrist som andre programmer og er siden sommeren 2010 innlemmet i Nordplus' hjemmesider.

Nordplus språk og kultur utenforstatus medførte i starten at det forelå to ulike grunnlagsdokumenter for programmet. Det var derfor uklart om det felles programdokumentet «Common Program Document» (CPD) som lå til grunn for rammeprogrammene innenfor Nordplus-ordningen også gjaldt for NSK. Konkret var spørsmålet om kravet om egenfinansiering også skulle gjøres gjeldende for språk og kultur (noe som ikke var nevnt i det ene av grunnlagsdokumentene). Programkomiteen ønsket et lavere krav om egenfinansiering enn femti prosent for dem som fikk søknadene innvilget (Egenevaluering, 2010: 2). Diskusjonen viser at kravet om det programkomiteen oppfatter som en høy og muligens ekskluderende egenandel for noen søkere, har vært løftet fram i NSK. Den kan også ses som et uttrykk for en generell uklarhet om hvilke rammevilkår som gjaldt for et program som var assosiert til Nordplus-ordningen. Hvor stor frihet hadde programkomiteen til å definere vilkårene for organisasjon og drift? Konklusjonen ble, gjennom et vedtak i Nordisk ministerråd, at de samme organisatoriske rammevilkårene herunder egenfinansiering som gjaldt for øvrige programmer, også skulle gjelde for Nordplus språk og kultur. 


\subsubsection{Språk, et tverrgående engasjement og program}

Språk er både et særskilt program i Nordplus, samtidig som fellesskapet språk, kultur og livsvilkår er en gjennomgripende og grunnleggende motivasjon for det nordiske samarbeidet. Kunnskapsfeltet operasjonalisert til et program kan ha tre dimensjoner: 1) Gjennom språklig innsikt vil kunnskap om og forståelsen for de nordiske kulturvarianter og livsformer styrkes. 2) Det muliggjør og styrker kommunikasjon spesielt på skandinaviske språk og styrker læringen av skandinaviske språk som målspråk. 3) Programmet bidrar til å utvikle et fag/vitenskapelig disiplin gjennom utviklingsarbeid og forskning på nordiske språk som studieobjekt. Det har betydning å fastholde dette kunnskapsfeltet som et eget satsingsområde. En medadministrator for programmet sammenlignet den nordiske måten å organisere språkfeltet på med den i EU. Vedkommende uttrykte fordelen med Nordplus’ ordningen slik:

Man ser i LLP (livslang læring) at det er vanskelig å fastholde språk innenfor en mer integrert form.

Nordplus' ordning med en hovedadministrator og medadministratorer for hvert av rammeprogrammene, kan være en styrke for et program av den tverrgående typen som språk og kultur ikke minst fordi administratorene på nasjonalt hold kan ha større innsikt i ulike nasjonale særtrekk når det gjelder språkspørsmål.

\subsubsection{Målsettinger}

Operasjonaliseringen av programmets mål ble i 2010 konkretisert som følger:

- aktiviteter som styrker barn og ungdoms språkforståelse (dansk, norsk og svensk), jfr språkkampanjen

- aktiviteter som angir fremgangsmåter for hvordan dansk, norsk og svensk kan læres på best mulig måte på Færøyene, Grønland, Island og i de samiske områdene.

- aktiviteter som viderefører arbeidet med «sprogpiloterne», i forbindelse med utdannelse av ungdommer (14-19 år)

- aktiviteter som styrker ivaretakelsen av språkforståelse i lærerutdannelser og som styrker samarbeid om språkstrategi innenfor nordisk lærerutdannelse

- aktiviteter som inneholder refleksjoner over universitetenes valg av undervisningsspråk, språkteknologisk samarbeid og utviklingssamarbeid (Nordplus 2008-2011, Håndbok 2010: 52).

Tre typer temaområder er gitt prioritet: 1) barn, unge og læreres forståelse av skandinaviske språk, 2) å utvikle og bruke ny teknologi for å lære å forstå skandinaviske språk og 3) språkvalg på språkbruksarenaen Høyere utdanning. 
For den andre søknadsrunden i 2010, med frist medio oktober, ble barn og unges språkforståelse med hensyn til de skandinaviske språkene nok engang prioritert. NSK satsning på barn og unge samsvarer med politiske signaler fra nordiske politikere. Det er en oppfølging og konkretisering av Helsingforsavtalen (1962); Deklarasjon om nordisk språkpolitikk (2006) og Ekspertgruppens arbeidsoppgaver (www.norden.org; godkendte retningslinjer for Ekspertgruppen Nordens Sprogråd (ENS)). Samtidig spiller også intensjoner for Nordplus generelt om økt mobilitet i Norden inn.

I løpet av inneværende programperiode har de prioriterte målene til sammen vært relativt mange. Spørsmålet er om dette er uttrykk for en første fase, der det nye programmet arbeider for å finne sin profil, eller for et ønske om å innfri mange og ulike forventinger og ønsker. En annen sak er om prioriteringene samsvarer med de søknadene som kommer inn, og dem som innvilges midler. Det kan synes som om programmet i første fase med en ny struktur, nye aktivitetstyper og delvis andre grupper av søkere, har arbeidet for å finne sin form.

\subsubsection{Et språkprogram, ikke egentlig et kulturprogram?}

Programmet heter nordisk språk og kultur, der kulturdelen i navnet hovedsak stammer fra at mobilitetsprosjekter ble tilført fra Juniorprogrammet, og at denne aktiviteten hadde en bredere målsetting enn rent språkmessige. Utvidelsen av programmet har derfor bidratt til en mer diffus identitet - ikke minst hos potensielle brukere av programmet.

I håndboken er profilen forsøkt styrket ved at man legger vekt på språkets allmenne betydning som kulturformidler og kulturbærer (Nordplus 2008-2011, Håndbok 2010: 53). Men gjennom sine prioriterte mål er det langt på vei et språkprogram. En medadministrator forsøkte for eksempel å engasjere kunstnere i sitt land for å søke innenfor språk og kultur, men det ga lite. Det finnes for øvrig flere etablerte initiativ for å støtte kulturuttrykk i Nordisk ministerråds regi utenom dette programmet.

\subsubsection{Programmets to deler: mobilitet og språk}

For å fremme de tematiske målene støtter NSK en rekke ulike aktiviteter og tiltak, de er rettet mot ulike og delvis spesifikke målgrupper: Den ene typen tiltak kalles her med et fellesnavn for mobilitetsdelen og den andre for språkdelen. I mobilitetsdelen er aktivitetene rettet mot kunnskaps- og personutveksling av elever og pedagogisk personale mellom de nordiske landene i grunnskolen og i den videregående skolen. I språkdelen gis det støtte til nettverks- og prosjektaktiviteter.

- mobilitetsdelen:

- kunnskapsutveksling, klasseutveksling og utvekslinger av lærere og annet pedagogisk personale 
- språkdelen

- opplysningsarbeid

- konferanser

- kursvirksomhet

- publikasjoner

- forskningsprosjekter

- språkteknologiske prosjekter

- ordbok- og terminologiarbeid

- utvikling og utgivelse av læremidler

Språk- og kulturprogrammet er altså delt i to deler. Denne delingen understrekes av en regel om at 30 prosent av midlene er øremerket mobilitetsdelen (2 mill DKK) og 70 prosent språkdelen. Mens språkdelen er en videreføring av det tidligere Nordplus språk, så er aktivitetene i mobilitetsdelen ny fra 2008. Den er rettet mot elev- og lærerutveksling på grunnopplæringsnivå og inngår i et overordnet mål om å styrke nabospråkforståelsen blant barn og unge og å styrke opplæringen om samfunnsforhold i andre nordiske land. Mobilitetsdelen overlapper til dels med Nordplus junior og var også samlet i junior inntil reorganiseringen.

Aktivitetene i språkdelen er preget av etablerte kategorier og samarbeid med etablerte, profesjonelle aktører på feltet, flere av dem forskere og forskergrupper innenfor språkfagene, herunder terminologi- og ordboksarbeid (Nordplus 2008-2011, Håndbok 2010: 53). Mange av søkerne til dette programmet er faglig/vitenskapelig kvalifiserte innenfor studier av nordiske språk, og blant listen av tiltak er mange aktiviteter som kan knyttes til faglige prosjekter, nettverk og øvrig FoU-arbeid.

\subsubsection{Programkomiteen, ekspertgruppen Nordens språkråd (ENS)}

Nåværende ENS avløste i 2009 den tidligere styringsgruppen for programmet Nordens språkråd som da ble nedlagt. Det var opprettet av ministerrådet i 2004, og i styret satt utsendinger fra alle de nordiske landene, der flertallet av disse var fagfolk. Det foregående programmet var i følge forrige evaluering preget av en nærhet mellom fag- og forskningsmiljøer i nordistikk og programkomiteen. Fordi medlemmer av daværende Nordens språkråd hyppig befant seg blant søkerne, ble det pekt på mulige habilitetsproblemer og behov for habilitetsregler (Vabø 2006: 36-37).

Det samlede språkarbeidet i Nordisk ministerråd, herunder NSK, ble omstrukturert etter omorganiseringen av språkområdet. Dagens programkomité ENS består av ti medlemmer: en ekspert fra Danmark, Island, Norge og Sverige, to fra Finland, en fra de selvstyrende områdene: Færøyene, Grønland og Åland og dessuten en ekspert fra Sametinget. Medlemmene oppnevnes av Nordisk ministerråd etter forslag fra de respektive statenes departementer. Majoriteten av dem har forskerkompetanse på første-/toppstillingsnivå innenfor nordistikk og/eller språkvitenskap. ENS har foruten programkomite- 
oppgaven i NSK også andre rådgivende oppgaver i det nordiske språkarbeidet som har sitt utgangspunkt i Nordisk ministerråd. ENS samarbeider med Nordisk språkkoordinasjon som fysisk sett holder hus i «Dansk sprognævn» og har driftsstøtte og midler til rådighet fra Nordisk ministerråd. Den nordiske språkkoordinasjonen har fra 2009 overtatt ansvaret for å støtte faste tiltak som nordiske perler, Nordkurs og Nordspråk, og dessuten samarbeidsnevnden for de nordiske språkrådene. ${ }^{1}$ Språkkoordinasjonen har også en rolle når det gjelder å identifisere og spre erfaringer fra NSK.

I tillegg har språkkoordinasjonen også ansvaret for Nordisk ministerråds satsing på «Den nordiske språkkampanjen» som er rettet mot at barn og unge i Norden skal lære å forstå hverandres språk. Habilitetsproblemet innenfor språkområdet synes å ha vært tatt på alvor og den nye ordningen har løst opp noen av de tette båndene mellom det tidligere Nordens språkråd og Nordplus-programmet. Samtidig har medlemmer av ENS også i nåværende programperiode vært medsøkere på prosjekter, og habilitetsproblematikken er fremdeles et forhold man bør være oppmerksom på. Etableringen av ENS har likevel medført at programarbeidet i NSK foregår under en mer reflektert og større språkpolitisk horisont.

\subsection{Administrasjon og drift av programmet}

Hovedadministrasjonen for Nordplus nordisk språk og kultur er lagt til Háskoli Íslands og dets «Det Internationale Kontor for Uddannelse». Oppdraget er regulert nasjonalt med en kontrakt med det islandske undervisningsdepartementet. At språk- og kulturprogrammet holder hus på Island, der språkpolitikk kanskje er et særlig viktig nasjonalt anliggende og der kontakten med den nordiske kulturen og de skandinaviske språkene har lange tradisjoner, er nok ingen ulempe for programmet. Følgene av de seneste årenes finansielle krise på Island kan ha medvirket til en forsterket oppmerksomhet om de muligheter som dette nordiske programmet gir islandske fagmiljøer, skoler og andre grupper om støtte, men kan også ha hatt den bieffekt at islandske aktører i dag spiller en relativt dominerende rolle i programmet.

I relasjon til drift og administrasjon av programmet synes språk og kultur å fungere utmerket. Samarbeidet mellom programkomiteen og administrasjonen synes å fungere godt (Egenevaluering, 2010: 3, intervjuer med administratorer). Vurderingene av innkomne søknader til programmet synes også å gå greit. Språkdelen har langt på vei en søkergruppe med etablerte normer og tradisjoner for faglig arbeid og en kunnskaps- og organisatorisk struktur som Nordplus aktiviteter glir lett inn i, og kravene til rapportering er kjente. Mobilitetsdelen byr på større utfordringer for skoler. Disse har ofte svakere administrative strukturer og er mindre vant med å håndtere de kravene som stilles til søknadsskrivning og rapportering. Besøk på videregående skoler der skoleklasser med lærere hadde vært på utveksling til et annet nordiske

\footnotetext{
1 ww.dsn.dk.
} 
land, viste imidlertid at disse skolene hadde satt av ressurser til koordinering og administrasjon. Også her var arbeidet fulgt av et engasjement for betydningen av skandinaviske språk og kulturelt fellesskap i Norden, som oversteg de yrkesmessige forpliktelsene på lærersiden. For mobilitetsdelen behøver ikke søkeren bidra med noen egenandel for mobilitetsaktiviteten, likevel er det ikke klart om de faste satsene dekker alt. Det vil ofte være behov for egeninnsats i form av medgått tid, slik som til faglig og praktisk planlegging. Denne egenfinansieringen kan ta form av arbeidstid, eller også medfinansiering fra skolen og/eller privat.

Sett fra et brukerståsted oppleves administrasjonen av programmet, så langt evaluatorene kan bedømme, som uproblematisk. Brukere roste hovedadministrasjonen for dens tilgjengelighet, informasjonen og den løpende og gode hjelpen de hadde fått for å realisere klassebesøk til andre nordiske land. Brukere av språkdelen fremhevet spesielt administrasjonens tilgjengelighet, effektivitet og fleksibilitet i forhold til søknader og innvilgede prosjekter.

\subsubsection{Søknads- og rapporteringssystemet, ARS}

Innføringen av et nytt søknads- og rapporteringssystem (ARS) i 2008 skapte store vansker for administrasjonen og for søkerne. Vanskene ble forklart både med at systemet rent teknisk ikke fungerte og som et resultat av hvordan ARS er bygd opp. Det første året gikk det med mye tid og arbeid, inkludert ekstra lokale hjelpeløsninger for å få søknaden lagt inn og behandlingen til å virke. Når det gjelder å sende inn søknader, synes de alvorligste vanskene å være overvunnet. Men i forhold til hovedadministrators behov for analyse og rapportering fungerer systemet ikke etter hensikten. Det rapporteres om at det er vanskelig å bruke systemet for å hente ut relevant statistisk og annen informasjon som saksbehandlere har behov for. Innenfor språk og kultur ble det fra programkomiteens side uttrykt misnøye med at systemet kun forelå på engelsk (noe som i hovedsak skyldes den tekniske utformingen av ARS). Det hevdes at dette ga feil signaler til brukerne og søkere for et program der formålet er å styrke kunnskapen om og forståelsen for av språk i Norden. Nå er det riktignok etablert en mulighet til å velge en skandinavisk (norsk) versjon etter at søknadsprogrammet er åpnet på engelsk. Slik sett er engelsk førstevalget og et skandinavisk språk andrevalget - et noe spesielt signal å sende ut for et språkprogram.

\subsection{Profilering, spredning og informasjonsarbeid}

Det viktigste, felles verktøyet for Nordplus er den felles hjemmesiden www. nordplusonline.org som gir en oversikt over Nordplus' rammeprogram. Under denne hovedsiden har hvert av delprogrammene sin egen underside. Inntil sommeren 2010 var Nordplus, språk og kultur som altså formelt står 
utenfor rammeprogrammene, ikke en del av denne ordningen, men er nå innlemmet på en felles hjemmeside.

Språk og kultur nyter godt av de ulike Nordplus-kontorenes erfaringer og kommunikasjonskanaler. Nordplus-ordningen med en hovedadministrasjon og medadministrasjoner har klare fordeler når det gjelder å nå fram til sine målgrupper innenfor språk. At administratorer finnes i hvert land burde slik sett gi en lav terskel for kontakt. Språkfeltet har imidlertid flere nettverk og ressurser å trekke på i det nordiske samarbeid, og enkelte brukere har ytret ønske om et enda tettere samarbeid mellom NSK og eksempelvis Nordisk Språkkoordinasjon knyttet til formidling og kunnskapsutveksling.

NSK synes opptatt av å spre kunnskap om sitt program. Årlig har administrasjonen foretatt en kartlegging blant sine medadministratorer om hvordan de informerer om programmet språk og kultur. Hovedadministrator synes å ha som politikk at de skal stimulere til en åpen og regelmessig kommunikasjon om informasjon og programadministrasjonens arbeid (Egenevaluering, 2010:4).

Nordplus, språk og kultur henvender seg to ganske ulike målgrupper: personer innenfor forskning og Høyere utdanning og for det andre, barn, unge og skoleklasser og lærere i skoleverket. Generelt er det komplisert å profilere et program som skal nå slike ulike målgrupper.

\subsubsection{EU og Nordplus språk og kultur}

Mobilitetsdelen kan oppleve konkurranse fra EU-programmer, mens språkdelen i kraft av sitt innhold er unikt nordisk og uten noen konkurranse fra EU-programmer. Nordisk ministerråds fokus synes derfor å være viktig for kunnskapsområdet.

\subsection{Måloppnåelse og resultater}

Tabell 6.1 NSK, søknader og søknadsbeløp 2008-2010

\begin{tabular}{lrrl}
\hline År & $\mathbf{2 0 0 8}$ & $\mathbf{2 0 0 9}$ & \multicolumn{2}{l}{$\mathbf{2 0 1 0}$} \\
\hline Antall søknader & 48 & 43 & 82 (vår 46 og høst 36) \\
totalt søkt søknadsbeløp & 1841176 & 1381854 & 921376 (kun vår) \\
Innvilgede søknader & 37 & 36 & 56 (vår 35 og høst 21) \\
totalt innvilget søknadsbeløp & 1083360 & 965950 & 593 3030 (kun vår) \\
\hline
\end{tabular}

Kilde: SIU, 2010

Samlet sett har innvilgelsesprosenten vært høy i perioden 2008-2010, mellom 70 og 80 prosent. Erfaringene fra søknadsrundene i 2008, 2009 og fra første runde i 2010 er en viss rikelighet av midler - noe som ikke minst åpnet for nok en søknadsrunde høsten 2010. Denne situasjonen kan skyldes flere, ulike omstendigheter: omlegging av kriteriene for å søke med noen typer bevilgninger som var overført direkte fra Nordisk ministerråd. Videre ny søknadsfrist og et nytt søknadssystem, ARS, som spesielt i 2008 ikke fungerte tilfredsstillende, 
samt finanskrisen i Europa og på Island som skapte stor usikkerhet. For utdelingen i 2010 var situasjonen slik at da de kvalitetsmessig gode og støtteverdige prosjektene var valgt ut, stod fremdeles en sum til rådighet. Derfor ble en ny søknadsrunde, denne gang med frist medio oktober gjennomført, og hele 21 nye prosjekter ble da innvilget støtte. Dette kan tyde på at flere søknadsfrister også kan stimulere til en økning i det totale søkerantallet.

\subsubsection{NSK - mobilitet og språk}

Midlene fordeles som nevnt med 30 prosent til en mobilitetsdel og 70 prosent til en språkdel. Innvilgelsesprosenten er generelt høy og om lag den samme for både språkdelen og mobilitetsdelen av programmet.

I følge egenevalueringen er nåværende budsjett for tiden tilstrekkelig for å støtte et rimelig antall kvalitative prosjekter. I forhold til det tidligere Nordplus språk gikk antallet søknader ned, fra 67 i 2006 til 48 i 2008 når det nåværende programmet startet (Egenevaluering Nordplus sprog- og kulturprogram, 2009:1). Inntil reorganisering i 2008 var imidlertid det daværende Nordplus språk preget av en rekke «faste abonnementer» til midlene. Følgen av at midler til andre prosjekter var få var dermed at mange søkere måtte avvises. Den nære tilknytningen til et fag- og forskningsmiljø i nordistikk forsterker imidlertid tyngden og kontinuiteten i søkermassen. Programmet har nå en åpning til å støtte nyskapende prosjekter, og det på et felt der søkerne, ordninger og nettverkene er vel etablert.

\subsubsection{Koordinatorer og partnere i NSK}

Ser man nærmere på antallet prosjekter fordelt på land - herunder hvem som er koordinatorer - er bildet at Island er det mest aktive landet i NSK, tett fulgt av Norge.

Når det gjelder de øvrige nordiske landene deltakelse i NSK, har de i mindre grad tatt på seg oppgaven som koordinator, men deltar i større grad heller som partnere, ikke minst gjelder dette Danmark.

Hvorfor Island og Norge er de aller mest aktive i NSK er noe uklart. Tatt i betraktning at Islands folketall er mindre enn ti prosent av det norske, er den islandske deltakelsen svært oppsiktsvekkende. Felles for Island og Norge er også både at de begge har et høyt og omlagt likt antall av både koordinatorer og partnere. En mulig forklaring kan være at man i disse landene har stor interesse for språkspørsmål, og der dette er en viktig motivasjon for også å ta ledelsen av slike prosjekter. At terskelen for å ta kontakt med den islandske hovedadministrator kan være lavere for islendinger enn for søkere i andre land, er en annen mulig forklaring.

Sammenlignet med andre Nordplusprogrammer er det totale antallet prosjekter relativt lavt i NSK, især når det gjelder partnere. Mange av koordinatorene er skoler på grunnopplæringsnivå, og de er ofte knyttet til mobilitetsdelen av programmet. FoU-institusjoner utgjør mange av de andre koordinatorene. 
Det synes å være en tendens til at FOU-institusjonene tilhører språkdelen da aktivitetene som utføres ved de øvrige institusjonstypene synes å kreve formell kompetanse innenfor språkfag (oversikt over tildelte søknader 2009).

Beste praksis - Lær islandsk på internett

Blant de mange aktiviteter Nordplus har støttet er prosjekt «Icelandic online» www.icelandic.hi.is. Det er et gratis språkkurs for dem som trenger eller ønsker å lære seg islandsk. Programmet er åpent for alle, men utformet med to målgrupper for øyet: dem som vil lære islandsk for (først og fremst) å klare seg i det praktiske hverdagslivet på Island, og dem som lærer for å studere og avlegge en ferdighetseksamen i islandsk. Bak programmet ligger en nyskapende språkteknologi. «Icelandic online» bidrar til å stimulere interessen for og kunnskapen om nordiske kulturer; det kan styrke språkforståelsen for et språk i Norden og dessuten medvirke til forskning og fagdidaktikk innenfor språkstudier.

Av tre grunner mener vi dette programmet kan stå som et eksempel på beste praksis i Nordplus.

Programmets innhold og form

- Det bidrar til å utbre kunnskap om et nordisk språk og styrke interessen for dem

- Det styrker et språk med relativt mindre antall morsmålsbrukere.

- Programmet er på samme tid

o en språkopplæring for nyankomne som trenger islandsk for å mestre dagliglivet.

o en opplæring for dem med behov for å bestå en språkeksamen i islandsk

o opplæring for dem med allmenn interesse for språk.

- Det er forskningsfundert i språkvitenskap og didaktisk faglig kvalitetssikret.

- Det er et aktivt forsøk på å knytte sammen språk og kultur, religion, dagligliv og historie (mest på mer avanserte nivåer i språkopplæringen)

- Programmet viser på en utmerket måte hvordan informasjonsteknologi og grafisk vevdesign kan utvikles og anvendes for digitale læremidler

Bruk av midler fra Nordplus-ordningen

- Egenandelen på femti prosent består av arbeidstimer som ansatte ved Háskolí Íslands har lagt ned i prosjektet.

- Resultatet av prosjektet er åpent tilgjengelig for allmennheten

Tilleggseffekter for Nordplus

- Det er et enkelt og relevant tilbud om språkopplæring for studenter på utveksling i Nordplus' regi og andre stipendprogrammer.

- Ideen kan overtas og videreutvikles og kobles mot andre programmer under Nordplus-paraplyen: for eksempel Høyere utdanning og Horisontal. 


\subsection{Samlet vurdering}

Nordplus' overordnede mål om at kunnskap om og gjensidig forståelse av ulike livsvilkår, tenkemåter og andre kulturuttrykk i Norden er grunnleggende viktig for at nordisk fellesskap styrkes gjennom programmer av typen Nordplus nordisk språk og kultur. Nåværende språk- og kulturprogram er en konkretisering av politiske ideer; dets nytte er ofte av immateriell karakter, men ikke mindre vesentlig av den grunn.

For arbeidet med de nordiske språkene betyr oppmerksomheten og den finansielle støtten fra Nordisk ministerråd mye. I det store og hele fungerer programmet språk og kultur meget bra. Det har imidlertid noen utfordringer: Noen av dem er av organisatorisk art, mens andre bunner i kunnskapsmessig og/eller politisk uavklarte forhold.

Innholdsmessig er programmets profil er per 2010 noe utydelig og det på fire måter. Det inneholder et bredt knippe av prioriterte målsettinger. En eventuell ide om en integrasjon mellom språk og kultur er knapt forsøkt gjennomført. Kulturdimensjonen har i praksis begrenset selvstendig betydning, språk- og kulturprogrammet 2008-2011 er langt på vei et språkprogram med en viss vekt på språket som kulturbærer- og formidler. Det er en noe uavklart situasjon mellom de nordiske språkene og de skandinaviske, men i sin operasjonalisering vektlegges de facto de skandinaviske språkene.

Programmet omfatter både en mobilitetsdel med en distinkt målgruppe og språkdel med andre målgrupper. Profilen til NSK ville bli tydeligere om mobilitetsdelen ble flyttet til Nordplus junior. På den måten ville alle mobilitetstiltak rettet mot samme type målgruppe bli samlet i et og samme program. Nordplus junior ville også bli styrket som program, og søkere vil få det enklere om det var ett og ikke to programmer å forholde seg til. For å styrke ideen om språklig læring og styrking, kunne det kreves at all klasseog lærerutveksling i de skandinaviske landene skjer på et skandinavisk språk, eventuelt kunne midler til dette formålet øremerkes.

På den organisatoriske siden nyter programmet godt av at det i praksis inngår i Nordplus som er en organisasjon med god samlet kunnskap om de ulike, relevante målgrupper for programmet, og der det foregår gjensidig utveksling av denne kunnskapen. Den islandske hovedadministrasjonen fungerer utmerket, programmet er effektivt administrert, og administratorenes engasjement for å drifte, profilere og realisere programmets mål strekker seg langt. Ressursrammene er rimelig sett i forhold til antallet søknader, og antallet innvilgede prosjekter bevilget til formålet. Ressursene er etter NIFUs vurdering brukt hensiktsmessig og effektivt. Profileringen av programmet er i samsvar med de midler som står til rådighet. 



\section{Synspunkter fra de baltiske lande}

\subsection{Indledning}

I kølvandet på EU-udvidelsen i 2004 udpegede Nordisk ministerråds samarbejdsministre (MR-SAM) omstruktureringen af samarbejdet med de baltiske lande som et vigtigt strategisk mål. Siden da har samarbejdet med de baltiske lande i stadig større grad udviklet sig til et regulært myndighedssamarbejde mellem ligeværdige aktører, som finansierer fælles projekter. Estlands, Letlands og Litauens deltagelse i Nordplus programmerne blev et resultat og en konsekvens af denne omstrukturering på uddannelses- og forskningsområdet. Siden 2008 har de baltiske lande haft mulighed for at deltage på lige fod med de nordiske lande i alle Nordplus programmer, med undtagelse af de nordiske sprog- og kulturprogrammer.

I dette kapitel fremføres og vurderes synspunkter fra de baltiske lande. I forbindelse med den baltiske deltagelse i Nordplus programmerne har man givet udtryk for visse forbehold i forhold til mulige administrative konsekvenser og dilemmaer, som relaterer sig til sprogproblemer, baltisk medfinansiering og konsekvenser for styringsmodellen. Ud over det har inddragelsen af de baltiske lande uden tvivl ført til forøget opmærksomhed omkring tværkulturelle sammenhænge og fleresproglighed som en mulig rammebetingelse for alle partnere i Nordplus programmerne. Nu har man både på den baltiske og den nordiske side samlet erfaringer med hensyn til de baltiske landes deltagelse i Nordplus. Derfor har vi også i løbet at vores evalueringsarbejde fundet det hensigtsmæssigt at lade de nyankomne, baltiske partnere kaste lys over samarbejdet med hensyn til at vurdere og forbedre hele Nordplus programmet. En kvalitativ forbedring med aktiv deltagelse af de baltiske partnere medfører muligvis en institutionel omstrukturering af nogle samarbejdsfelter i Nordplus, hvilket behandles nærmere i anbefalingerne i slutningen af dette kapitel.

\subsection{Styringsstruktur og resurser}

I de første år af baltisk Nordplus deltagelse har repræsentanter for de baltiske programkontorer hverken fungeret som hovedansvarlige for et underprogram af Nordplus eller medansvarlige for de andre programmer. Denne organisationsmæssige beslutning har haft den fordel, at de baltiske partnere og administratorer har fået tid til at lære meget om programmernes organisation og administration. Samtidig har denne situation ført til, at den baltiske 
medbestemmelse i Nordplus ikke kunne realiseres i et omfang svarende til de baltiske landes ambitioner. Snarere har man stillet sig afventende over for Nordplus administrationen på de baltiske informationskontorer, hvor Nordplus programmerne hidtil er blevet sidestillet med en række EUprogrammer. Nu synes flere og flere af de administrative medarbejdere, som er beskæftiget på de baltiske informationskontorer, at være godt bekendt med forvaltningen af Nordplus programmet. Både i Letland og Estland og med mindre styrke i Litauen har man ytret ønske om at blive mere direkte inddraget i administrationen af Nordplus. Udnævnelsen af et arbejdsområde, hvor de baltiske lande føler sig stærke, og hvor der har ligget en længere tradition bag deres samarbejde, synes efterspurt. Flere informanter hevder at et Nordplus Kulturprogram, hvor de baltiske lande (på skift eller i fællesskab) kunne agere som hovedadministratorer, ville fremme målet om et tættere nordisk-baltisk samarbejde.

\subsubsection{Kultur som baltisk styrke}

Set fra baltisk side er tiden nu moden til at holde op med at stille sig som modtager i det europæiske eller baltisk-nordiske samarbejde og i større grad bidrage på de felter, hvor de baltiske land har deres styrke. Uden undtagelse har informanterne i de baltiske lande peget på kultursektoren som et felt, hvor baltisk kunst og kultur samt erfaring og kompetence i kulturformidlingen er relevant og på et meget højt niveau i sammenligning med de nordiske lande. På den baggrund synes informatene at det er hensigtsmæssigt i større grad at skelne mellem Sprog og Kultur i Nordplus rammeprogrammet med det mål for øje at oprette et nyt Nordplus Sprogprogram og et nyt Nordplus Kulturprogram, som i højere grad er tilpassede behovet for sprog- og kultursamarbejde mellem Baltikum og Norden. Flere af informanterne i de baltiske lande har imidlertid vist stor interesse for samt direkte ytret ønske om at komme til at stå for administrationen af Nordplus Kultur som et nyt program. Man mener, at de baltiske lande netop på det kulturelle område ville kunne markere sig bedre i det nordisk-baltiske samarbejde, samtidig med at man herigennem ville kunne skabe et øget fokus på baltisk kultur i de nordiske lande. For en nærmere diskusjon af disse synspunktene sett i forhold til Nordplusprogrammene mer overordnet - se kapittel 9.

\subsubsection{Finansiering}

Med hensyn til finansiering har man fra baltisk side ytret størst betænkelighed i forhold til Nordplus Junior. De baltiske informanter hævder, at 50\% egenfinansiering ofte er en umulig tærskel for de baltiske partnere for at indgå i et samarbejde. Dette skal ses i forhold til støtteordninger som kan opnås i f.eks. gjennom LLP programmet Comenius, hvor op til 100\% af forskellige aktiviteter kan finansieres med ekstern støtte. En 75\% andel i Nordplus med 25\% egenfinansiering ville sikkert hjælpe til at finde flere 
gode projekter, og det ville bidrage til at udligne store materielle forskelle mellem de nordiske og baltiske institutioner.

I tilfælde af Nordplus Junior ligger også de strukturelle problemer i de baltiske lande ofte til grund for forestillingen om, at programmets finansiering er problematisk eller utilstrækkelig. For eksempel styrer de lettiske folkeskoler ofte ikke selv deres økonomi men er i stedet underlagt administration fra kommunal side. Koordinering mellem skoler og lokale myndigheder er ofte problematisk, og det forekommer, at en koordinerende skole har problemer med at distribuere midlerne, da der mangler juridisk basis for den slags aktivitet. En løsning kunne være at overføre penge til skolernes såkaldte «donation account», som skolerne i højere grad råder over.

Uden tvivl afspejler disse bemærkninger og forslag de problemer, som har kendetegnet økonomien i de baltiske lande over de seneste år. Ordet «krise» bruges ofte som forklaring på, hvorfor det kan være smertefuldt og vanskeligt for de baltiske lande at yde årligt bidrag til Nordplus budgettet. Denne situation til trods synes den nuværende finansieringsmodel mht. programafgiften at tilgodese de baltiske landes interesser på længere sigt.

Nogle af de baltiske informanter har også ønsket sig en mulig kobling mellem finansiering og opprioritering af enkelte emner eller arbejdsområder, som så skulle opprioriteres som særligt ønsket $\mathrm{i}$ ansøgningerne $\mathrm{i}$ en periode. Informanterne har peget på klimaskift som et potentielt emne, der kan bruges som vejledende for øjeblikket. En sådan emneprioritering ville også skabe større opmærksomhed omkring Nordplus som repræsentativ for Norden, hvor spørgsmålet om klimaændring er blevet til en mærkevare i de seneste år.

Når talen falder på finansiering, synes den verdensomspændende økonomiske krise i høj grad at præge udtalelserne fra de baltiske informanter. For eksempel kan man spore en meget stor interesse for Nordplus' højere uddannelse blandt mange institutioner og enkeltpersoner, men en kneben støtte til de studerendes kost og logi gør, at de baltiske partnere kun i begrænset omfang bruger programmet. Man har fornemmelsen af, at den nuværende støtteordning primært tilgodeser de store og etablerede Nordplus netværker med deltagelse af udelukkende de nordiske lande. En løsning kunne være, at støtten til kost og logi tilpasses det niveau, der ydes inden for Erasmus programmet.

\subsection{Administrationen af programmerne}

Deltagelse fra Estland, Letland og Litauen bidrager til mere sproglig og lingvistisk heterogenitet inden for programaktiviteterne. Derfor har man i den daglige drift af programmerne, også de baltiske lande imellem, brugt engelsk som arbejdssprog. Til administration og drift af Nordplus programmerne har man brugt de veludviklede veludstyrede nationale kontorer, som har mange års erfaring med information, vejledning og behandling af ansøg- 
ninger inden for lignende programmer i EU. Kontorerne finanseres af «Archimedes Fundation» i Estland, «Education Exchanges Support Foundation» i Litauen og «State Education Development Agency» i Letland. De har sikret en national forankring af Nordplus programmet, samtidig med at der er skabt administrative synergieffekter.

Mangeårig erfaring med information, vejledning og behandling af ansøgninger i lignende programmer har vist sig som en stor fordel i anvendelsen af det fælles Ansøgnings- og rapporteringssystem (ARS) for alle områder af Nordplus. Man har også vurderet de seneste ændringer positivt, som er blevet foretaget i systemet. Samtidig har nogle af de estiske informanter ytret ønske om at finde en balance mellem det relativt ukomplicerede ansøgningssystem på den ene side og rapporteringssystemet på den anden side, som virker mere vanskeligt og volder større problemer for brugerne.

Set fra baltisk side er der dog stadig behov for træning i forvaltning af Nordplus programmet, hvor vægten kunne lægges på at lade programmets forvaltere fra de nordiske og baltiske lande mødes og udveksle erfaringer. Nordisk ministerråds sekretariat bør således vurdere flere former for oplæring, eksempelvis i form af seminarer, konferencer, gæsteophold, som især ville fremme mobiliteten af nordiske forvaltere til Baltikum og baltiske til Norden. Man kunne ligeledes ønske sig seminarer for personer, der er ansvarlige for Nordplus på det ministerielle niveau. Repræsentanter fra de baltiske landes uddannelses- og forskningsdepartementer, som træffer de egentlige beslutninger vedrørende finansiering, skal informeres bedre om forholdene landene imellem, således at man er bedre klædt på til at tackle eventuelle fremtidige problemer.

\subsubsection{Sprog kan væere nøglen til nordisk-baltisk samarbejde}

Ifølge Ministerrådets sprogpolitik skal alt nordisk samarbejde foregå på et af de nordiske

sprog, fortrinsvis skandinavisk. I politik og forvaltning er dette mål stort set uproblematisk at realisere, men idealet om et fælles sprog at kommunikere på er langt fra en realitet i det nordiske samarbejde i almindelighed. Denne situation og problemer, som knytter sig til den, bliver endnu mere synlige, når repræsentanter fra de baltiske lande sætter sig ved et fælles bord i Nordplusregi.

Pragmatiske tilnærmelser til sprogbrug i det nordiske samarbejde til trods, anses nordisk sprog som det vigtigste fundament for et nordisk samarbejde i flere af Nordens sprogrådsanbefalinger. Ifølge dem bør dokumenter og udadrettede publikationer foreligge på mindst et nordisk sprog. De færdigheder i nordisk sprog, som præger det nordiske samarbejde, bidrager til, at det kan lade sig gøre at diskutere komplicerede spørgsmål af fælles interesse på et nordisk sprog. Set ud fra dette synspunkt adskiller samarbejdet med Baltikum, som foregår på engelsk, sig ikke fra andre typer af regionalt samarbejde mellem Østersølandene, eksempelvis Polen eller Rusland. Det 
nordiske samarbejde, som er baseret på sproglige, kulturelle, historiske og mange politiske fællestræk, sættes dermed «i relief», ifølge Nordens sprogråd.

De problemstillinger, som knytter sig til valg af sprog i nordisk-baltisk samarbejde, lader sig ikke løse på nogen enkel måde. At ophæve princippet om brug af et nordisk sprog, og lade al kommunikation foregå på engelsk vil tilskynde mange til at deltage, samtidig med at en særlig karakter af det nordiske samarbejde skulle redefineres. Man bør dog overveje at indføre et princip om, at den politiske og administrative kommunikation skal foregå på engelsk, hvilket ville ligestille de nordiske og baltiske partnere. Ellers skal der åbnes for fleresproglighed, afhængigt af projektets karakter. Flersproglige segmenter skulle samtidig fremmes inden for programvirksomheden.

Denne argumentation støder ikke på modstand i de baltiske lande. Tværtimod har muligheden for at tilegne sig de skandinaviske sprog bidraget til programmets udbredelse i de baltiske lande. De skandinaviske sprog forbindes med de skandinaviske/nordiske samfund og den skandinaviske/nordiske livsstil, som på forhånd nyder en stor respekt i de baltiske lande. Ønsket om at praktisere skandinaviske sprog i henholdsvis Litauen og Letland, og finsk i Estland, er en vigtig motivationsfaktor for at deltage i projekter og anses for et vigtigt aspekt ved læringsprocessen. Det gælder især de miljøer, hvor man allerede underviser i skandinaviske sprog. Traditionelt set er tilegnelsen af et skandinavisk sprog blevet forbundet med muligheden for at få adgang til den «vesteuropæiske» kulturpakke og livsmønstre, som lå lige for landenes grænser, og som man så gerne ville efterligne efter 1991.

\subsection{Profilering, spredning og informationsarbejde}

Da potentielle ansøgere fra de baltiske lande har en relativ begrænset erfaring med Nordplus, har det været en særlig udfordring for de nationale kontaktcentre, som varetager Nordplus ansøgnings-, sprednings- og informationsarbejde, at profilere programmet i forhold til øvrige EU programmer. Den primære kilde for information om Nordplus og programmets aktiviteter er således hjemmesider som:

- i Litauen http://www.smpf.lt/index.php?id=1593

- i Letland http://www.viaa.gov.lv/lat/starpvalstu_sadarbiiba/nordplus/nord plus_jaunumi/

- i Estland http://www.archimedes.ee/hkk/ .

De baltiske lande (og især Estland) har gjort den elektroniske kommunikation og internettilgang til alle borgere til deres mærkevare, som den økonomiske krise til trods delvis allerede er realiseret, delvis er under kraftig ud- 
vikling. Især i små landsbyer, hvor lokale biblioteker i de sidste år er blevet forvandlet til informationscentre inden for alle administrative opgaver og kulturelle entrepriser, er en omfattende on-line informationstjeneste en stor fordel. På grund af den store indsats og udbredte brug af internet i de baltiske lande synes satsningen på e-servicer som hovedinformationskilde som en passende løsning.

På baggrund af den overvejende positive erfaring og aktive brug af elektronisk kommunikation og internet har flere informanter pointeret nødvendigheden af en bedre udnyttelse af Nordplus programmets hjemmeside Man skulle for eksempel vise flere «best-case» projekter og berette aktivt om statistiske data angående løbende og udløbende projekter. Man har også ønsket at blive bedre informeret om arrangementer, som står i forbindelse med Nordplus programmet, herunder politisk diskussion om programmets udformning. Administratorer har også peget på muligheden af at udnytte hjemmesiden bedre til interaktiv dialog med ansøgere om programmet og projekter.

Ud over veludviklede og gennemtænkte hjemmesider har de baltiske lande brugt mere traditionelle midler til informationsarbejde i form af brochurer, pjecer samt informationsmøder. Det har blandt andet været en ret succesrig og godt gennemtænkt strategi at få inkluderet Nordplus projekter med en baltisk koordinator i en årlig projektudstilling «Baltic EXPRO +», hvor EXPRO er en forkortelse for «exhibition of projects». Initiativet hertil blev første gang taget i Tallinn i 2005, hvor man så EXPRO, som en mulighed for at få præsenteret LLP projekter i de baltiske lande. Siden 2009 har Nordplus været inkluderet i projektudstillingen. I alt blev der i Siaulai, Litauen, i 2009 præsenteret og diskuteret 52 projekter, hvoraf 7 blev realiseret i rammerne af Nordplus. Ved at sammensætte og sammenligne Nordplus projekter med andre kreative og innovative europæiske projekter har man formået at formidle budskabet om Nordplus, samtidig med at en mere brugervenlig ansøgningsprocedure i tilfælde af Nordplus er blevet fremhævet som en fordel for programmet.

\subsection{Målopnåelse og resultater}

Repræsentanter for uddannelsesmyndigheder og uddannelsesinstitutioner i de baltiske lande, som blev interviewet i forbindelse med evalueringen, giver alle udtryk for et forstærket og vedvarende ønske om at deltage i Nordplus programmet. Set fra deres synspunkt er deltagelsen i Nordplus programmet aktuelt, fordi der er en stor (og stigende) interesse blandt børn, unge, lærere og forskere i at deltage i denne type programaktivitet. Generelt anses Norden som et overkommeligt rejsemål for folkeskoleklasser på alle trin. Denne interesse fremmes og forstærkes bl.a. gennem positive erfaringer, som lærere fra Baltikum overvejende har gjort sig under deres ophold og udveksling med deres nordiske kollegaer. 
For størstedelen af informanterne og Nordplus forvalterne i de baltiske lande har det været en god strategi at basere nye Nordplus projekter på allerede eksisterende netværk og traditioner for samarbejde. Til gengæld har det været forholdsvis svært at finde helt nye partnere og interessen i et samarbejde om nye projekter har været vidt forskellig i de forskellige lande. For eksempel har flere litauiske informanter klaget over, at det udelukkende er danskerne, som udviser interesse i at indgå i et samarbejde, mens de øvrige nordiske potentielle partnere ikke udviser nogen villighed til at indgå i fælles projekter. Et lignende mønster for kommunikation finder man i Estland, hvor det primært er kolleger og institutioner i Finland, som hurtigst vender tilbage med positiv respons og viser sig mest villige til at indgå et samarbejde med nye partnere.

Samarbejdsmønstre i Nordplus' højere uddannelsesprogram viser, at der bygges videre på gode erfaringer og forbindelser, som blev etableret under Nordplus Nabo programmet. Med hensyn til bedre udnyttelse af human kapital inden for højere uddannelse blev der dog udtrykt skuffelse over, at de baltiske lande ikke kan være med i ansøgninger om Nordisk Master Program. At lade forsknings- og højere uddannelsesinstitutioner fra Baltikum deltage i programmet ville sikkert bidrage til, at der skabes en større samhørighed mellem de baltiske og nordiske universiteter, samtidig med at man også ville påvirke de pågående strukturelle ændringer inden for højere uddannelse i de baltiske lande.

Feltet voksenundervisning er et broget felt i Baltikum. Nogle steder er det først under udvikling, mens man andre steder, især i storbyerne, allerede har mange institutioner både i offentligt og privat regi. Nordplus Voksen er for dem en ideel støtteordning, idet man herigennem ville kunne udbrede den nordiske tradition for folkeoplysning i Baltikum I alt har de baltiske lande for få tilbud af denne slags og Nordplus støtteordninger sætter trends i denne sektor. Fra informationskontorernes side (især i Letland) har man anmodet om en mere præcis definition af, hvad voksenundervisningen helt eksakt går ud på Samtidig ville en enklere ansøgningsprocedure sikkert bidrage til flere ansøgninger fra institutioner og organisationer i de baltiske lande.

Nordplus programmerne er relevante (for Baltikum), fordi der er betydelig interesse for at lære skandinaviske sprog. I Estland, Letland og Litauen findes der også flere videregående skoler, som underviser i skandinaviske sprog, og interessen har været stigende i de seneste år. I denne sammenhæng bliver kulturelle lighedstræk også fremhævet. Dog uden fuldbyrdet baltisk deltagelse i Nordplus Sprog og Kultur program har muligheden for at søge støtte til den slags aktiviteter været begrænset. Flere informanter gav udtryk for, at det ville være ønskværdigt, om man implementerede sprogtilegnelse som en naturlig del af alle projekter, hvor man kunne bruge forberedelsesfasen til sprogkurser. Således ville partnernes kommunikationsevne være styrket, når samarbejdet starter, og engelsk ville ikke få så dominerende en stilling i samarbejdet. 
Inkludering af de baltiske lande i Nordplus-programmet har forbedret forudsætningerne for at få den nødvendige kritiske masse til at gennemføre projekter af en vis betydning. Åbningen har også givet flere muligheder for arbejdsdeling og styrkelse af kvaliteten inden for de nordiske uddannelsesmiljøer, selv om det nordisk-baltiske samarbejde om fælles studieprogrammer stadig lader meget tilbage at ønske. Dette kunne også skabe et bedre fundament for at tiltrække studerende. til udvekslingsprojekter inden for det nordisk-baltiske område og fra andre lande/regioner. Det kunne i hvert fald forbedre den nuværende situation, hvor det stadigvæk er vanskeligt at tiltrække nok elever, lærere, forskere og studerende fra Norden til Baltikum. Inden for sektoren højere uddannelse kunne løsningen også være at satse meget mere på at videreudvikle og bygge oven på oprindeligt statsvidenskabelige temaer («Baltic study programs» eller «Baltic Sea Region Studies»), hvor den ontologiske forståelse af en fælles nordisk-baltisk region og interessefællesskab redefineres. Dette studieprogram egner sig godt til at få støtte fra Nordic Master Program - om det bliver tilladt for de baltiske lande at søge.

På lignende vis har der hersket en udbredt opfattelse af, at man har satset for lidt på at støtte arbejdet med problemstillinger, som er fælles for baltisk/nordisk skole, som for eksempel: kvalitet i læreuddannelsen, højt frafald på videregående og højere uddannelser, klasserumssituationen (særlig problemer med elever mellem 13 og 16 år), demografiske ændringers betydning for skolen (eksempelvis sætter den faldende fødselsrate landskolerne under pres), integration af elever med specielle behov (psykisk og fysisk handicappede), og pensumudvikling. En prioritering af støtte til disse områder/emner i samarbejdet kan involvere lærere og elever i skolen på tværs af landegrænser.

\subsection{Samlet vurdering}

Trang til internationalisering i de Baltiske lande kan spores både på det institutionelle og det individuelle niveau. Nordplus programmet opfattes helt klart som et af midlerne til at fremme internationalisering. Man behøver ikke at søge langt for at få gode samarbejdspartnere. Nogle af informanterne brugte deres erfaring fra Nordplus ansøgningerne til at søge midler til store projekter på EU-plan. Estiske informanter fra et Nordplus Voksen projekt berettede om, at succesen i Nordplus gav dem mod til at arbejde på større europæiske projekter og indsende ansøgninger til EU.

Alle nordiske lande er højt respekteret og kendt som gode og pålidelige naboer, og sjældent ytrer man sig kritisk om de støttemuligheder, som Nordplus byder på og de betingelser, som skal opfyldes for at få støtte til realisering af projekter.

Med hensyn til håndtering af den administrative procedure i ansøgningsprocessen har man ikke nogen store vanskeligheder i de baltiske lande. Sna- 
rere retter kritikken sig mod princippet om egenfinansiering eller medfinansiering i projekterne. Flere gange blev der peget på store forskelle i den materielle situation og velstandsniveauet, som gør sig gældende i henholdsvis de nordiske og de baltiske lande, som kan hindre dårligere stillede skoler i Baltikum i at samarbejde (f.eks. mobilitet af elever kunne dårligt realiseres, da det af sociale grunde var umuligt at finde gæstefamilier for norske elever, som kom på udveksling til Letland). 



\section{Sammenfattende vurdering og hovedkonklusjoner}

Mens de foregående kapitler i hovedsak har hatt fokus på det enkelte program, skal vi i dette kapittelet gi en mer sammenfattende oppsummering og vurdering på tvers av programmene der fellestrekk, men også felles utfordringer kan løftes frem mer overordnet. I fremstillingen tilsvarer underoverskriftene de fem spørsmål som evalueringen spesielt er bedt om å se nærmere på (se kapittel 1). I tillegg er forhold rundt ARS diskutert som et eget punkt.

\subsection{Funksjonaliteten til, struktur på og styring av programmene}

Ser man på programmene sett under ett er det generelle inntrykket at noen programmer fungerer bedre enn andre når det gjelder profil, administrasjon og drift. En del av forskjellene skyldes utvilsomt forhold som ligger utenfor ansvarsområdet til det enkelte program: For det første er det store forskjeller i størrelsen på programmene - noe som utvilsomt kan være en utfordring når det gjelder saksbehandling og oppfølging. Nordplus Høyere utdanning og Nordplus Junior er - målt i antall søknader - de største programmene, og begge opplever at det kan være en kapasitetsmessig utfordring å håndtere saksbehandlingen på en god måte.

For det andre har noen programmer gjennom mange år hatt en tydelig og avgrenset faglig profil (NSK, Høyere utdanning), mens andre programmer enten er nylig etablert (Horisontal) eller hvor det har vært en innholdsmessig dreining (Junior) som har bidratt til økt kompleksitet og en justering av hva programmet skal være, noe som til en viss grad også kan ha bidratt til større grad av usikkerhet hos potensielle brukere. Når det gjelder Junior ser man eksempelvis at skolene ikke alltid har tilstrekkelige ressurser og kapasitet til å delta i programmet på de premisser som er lagt.

For det tredje er det også forskjeller knyttet til hvorvidt de ulike programmer har «konkurrenter» enten i det nordiske samarbeidet eller fra andre aktører herunder EU og deres LLP programmer. Noen brukere nevner eksempelvis at satsingen på «Nordiske Masterprogrammer» er noe man vet andre har vurdert som mer attraktivt enn mer ordinære søknader via Nordplus Høyere utdanning, og noe som også flere nevner kan være aktuelt som et alternativt for en selv i fremtiden. På samme måte synes en del brukere å være mer tiltrukket av mulighetene for å utvide nettverksaktivitetene geografisk i EUs LLP programmer. For disse brukerne er det internasjonalise- 
ring som sådan som fremstår som viktig, ikke det nordiske i seg selv. Det bør også nevnes at de økonomiske betingelsene knyttet til spesielt studentmobiliteten er noe bedre i LLP.

Målt i antall søknader til programmene ser man at det i perioden 20082010 sett under ett har vært en nedgang i søknadene til Nordplus Voksen, Høyere utdanning, Junior og til og med det relativt nystartede Horisontal (se tabell 8.1). Den største reduksjonen fant sted fra 2008-2009, og søknadstallet synes å ha stabilisert seg i 2010 (et viktig bidrag til at antall søknader går noe opp i 2010 er at NSK gjennomførte to søknadsrunder). Reduksjonen er størst innen Junior med en nedgang fra 340 til rundt 200 søknader fra 2008 til 2010, men reduksjonen er til dels også stor i de andre programmene. For Junior sin del er imidlertid en viktig forklaring at man i 2008 også åpnet opp for tre-årige søknader, noe som kan ha redusert antall potensielle søkere i årene etter. At Junior fikk en noe endret profil kan i forhold til NSK kan være en annen forklaring. I tillegg ble det innført nye søknadsrutiner der en koordinator står som søker også der ulike partnere er involvert. Andre forklaringer på nedgangen kan skyldes en svært høy aktivitet knyttet til informasjon og markedsføring i forkant av lanseringen i 2008, men der tilsvarende markedsføring ikke har vært gjentatt i samme omfang senere. Noen tekniske forklaringer knyttet til budsjetteringsmodellen i ARS, og vanskelighetene brukerne i sin tid hadde med å bruke denne, kan også ha relevans.

Tabell 8.1. Antall søkere til ulike Nordplus programmer 2008-2010.

\begin{tabular}{lrrr}
\hline & $\mathbf{2 0 0 8}$ & $\mathbf{2 0 0 9}$ & $\mathbf{2 0 1 0}$ \\
\hline Nordplus Voksen & 90 & 60 & 69 \\
Nordplus Høyere utdanning & 301 & 254 & 255 \\
Nordplus Horisontal & 46 & 35 & 32 \\
Nordplus Junior & 340 & 195 & 200 \\
NSK & 48 & 43 & 82 \\
SUM & 825 & 587 & 638 \\
\hline
\end{tabular}

At nedgangen generelt var spesielt stor fra 2008 til 2009 kan til en viss grad skyldes innføringen av ARS, men at man i liten grad har sett en økning i etterkant når funksjonaliteten til ARS har blitt bedre tyder på at innføringen av ARS neppe alene kan forklare denne utviklingen. Også i europeisk sammenheng ser man generelle indikasjoner på at tradisjonelle mobilitetsprogrammer ikke lenger er så attraktive, og at internasjonalisering synes å anta andre former (Janson et al 2009). At finanskrisen også kan ha spilt en rolle i nedgangen er heller ikke usannsynlig, men her er vårt datagrunnlag begrenset.

En intern analyse utført av hovedkoordinator synes i tillegg å indikere at det beløp man søker om, også har blitt sterkt redusert i de senere årene, og at søknadsbeløpet i større grad avspeiler mer realisme blant de som søker (SIU 2010c). Tendensen er tydeligst innen Høyere utdanning og Horisontal. Hva en eventuell økt realisme skyldes er usikkert, men her kan bl a god dialog mellom søkere og administratorer i forkant av søknadsprosessen, men også $ø k t$ erfaringsbasert kunnskap hos brukerne over tid være viktig. Det sist- 
nevnte indikerer imidlertid at mange søkere dermed må være «gjengangere» i programmene.

Selv om reduksjonen i antall søknader kan ses på som en indikasjon på at attraktiviteten i Nordplus programmene er noe redusert, synes reduksjonen ikke å ha hatt spesielt mye betydning for antallet prosjekter som har fått støtte via de ulike programmene i Nordplus familien. Mens det i 2008 var rundt 440 prosjekter som fikk støtte, er tallet i 2010 på 480 - et tall som faktisk innebærer en liten økning i prosjektene som har fått tilslag (se tabell 8.2 - her er imidlertid igjen en viktig årsak at NSK gjennomførte to søknadsrunder i 2010, noe som førte til at 21 nye prosjekter ble støttet høsten 2010). De største variasjonene som synes å forekomme innen dette bildet er at Junior har hatt en liten reduksjon i antallet støttede prosjekter, men Høyere utdanning har hatt en liten økning. Det forhold at antall støtteverdige prosjekter er opprettholdt mens antall innsendte søknader er redusert er en sterk indikasjon på at det har ikke manglet på støtteverdige prosjekter i Nordplusprogrammene. De ulike hovedadministratorene gir da også sterkt uttrykk for at kvaliteten på søknadene er opprettholdt, og endatil noe bedret ut fra at man har stilt strengere krav til søknadenes innhold, målspesifisering og gjennomføringsevne. Denne økte «formaliseringen» har på den ene siden bidratt til å skjerpe søkere og nettverk i forhold til behovet for nytenkning og en kritisk holdning til egne prosjekter - dette synes hensiktsmessig ut fra at mange søkere har mottatt støtte fra Nordplus også i tidligere programperioder, der tradisjon og rutiner kanskje har blitt for dominerende i utformingen og organiseringen av prosjektene. Her kan man også hevde at egenandelene - som er rapportert som et problem for en del brukere mange steder i rapporten - kan ha bidratt positivt til kvaliteten i prosjektene. Argumentet her er at egenandelen kan ses på som et uttrykk for en sterk motivasjon for å igangsette prosjektet, og at slik motivasjon er en viktig årsak til et godt prosjekt.

På den andre siden skal man også søke å finne en balanse i forhold til de krav som settes. Nordplus har over tid fått et ry på seg for å ha programmer med «lave terskler», fleksibilitet og enkle kommunikasjonslinjer. Dette er verdifulle egenskaper ved Nordplus og viktige virkemiddel i forhold til konkurrerende aktiviteter innen- og utenfor Norden.

Tabell 8.2. Antall innvilgende prosjekt 2008-2010

\begin{tabular}{lrrr}
\hline & $\mathbf{2 0 0 8}$ & $\mathbf{2 0 0 9}$ & $\mathbf{2 0 1 0}$ \\
\hline Nordplus Voksen & 43 & 40 & 43 \\
Nordplus Høyere utdanning & 191 & 210 & 217 \\
Nordplus Horisontal & 21 & 18 & 20 \\
Nordplus Junior & 151 & 135 & 143 \\
NSK & 37 & 36 & 56 \\
SUM & 443 & 439 & 480 \\
\hline
\end{tabular}

Ser man på programstrukturen og grensene mellom de ulike programmene synes det å være noen utfordringer med dagens inndeling. Som nevnt over er den ulike størrelsen på programmene en utfordring i seg selv for hovedadministratorene, og denne variasjonen bidrar til at kvalitetssikring og oppføl- 
ging av prosjektene nødvendigvis må bli varierende. Ser man eksempelvis på søknadenes suksessrate varierer den sterkt mellom programmene - fra 85 prosent i Høyere utdanning til 63 prosent i Horisontal. Her synes programmenes aktivitetsprofil å være en viktig forklaringsfaktor. I Høyere utdanning brukes mesteparten av ressursene til eksempelvis til mobilitet - som kan ha et avgrenset omfang.

Men heller ikke innholdsmessig synes dagens grenseoppgang mellom programmene å være veldig gjennomført. Et første eksempel er at man i Junior og i NSK har til dels overlappende aktiviteter (knyttet til mobilitet). Et annet eksempel er at man i Voksen og i Horisontal til dels kan finne de samme type prosjekter (spesielt innenfor utviklingsprosjekter og tematiske nettverk). Et tredje eksempel er at man i Høyere utdanning og i Horisontal kan finne en del relativt identiske utviklingsprosjekter (et eksempel er utvikling av nye studieprogram). Når det er sagt oppfattes i liten grad dagens programinndeling som et uoverkommelig problem verken av brukere eller administratorer. I tillegg er etableringen av Horisontal som et program som kan bidra til nytenkning, grenseoverskriding og fleksibilitet mottatt svært positivt og der programmet av mange brukere oppfattes å ha hatt en svært positiv betydning. Det forhold at man synes å ha opprettet Horisontal nærmest for å håndtere støtteverdige (og gjerne innovative) prosjekter som ikke «passer inn» i den eksisterende strukturen kan imidlertid også forstås som at dagens programinndeling ikke er optimal.

I forhold til styringen av programmene er generelt administratorer, komitémedlemmene og brukere positive til dagens matriseorganisering med hovedadministratorer og medadministratorer, programkomiteer, Nordplus hovedkomite, og andre styringsorganer. De fleste er enige i at denne styringsstrukturen skaper høy grad av medvirkning, tilhørighet og nærhet mellom aktørene.

Innenfor rammeprogrammet er programkomiteene formelt ansvarlig for aktiviteten i det enkelte program, og hovedkomiteens oppgave er først og fremst å overvåke de ulike delprogrammene, samt sette årlige prioriteringer for rammeprogrammene. Evalueringen har imidlertid avdekket av programkomiteene fungerer veldig ulikt, og at graden av engasjement og interesse for programområdet synes varierende blant medlemmene. En viktig oppgave for komiteene i dagens struktur har vært å få til en god faglig forankring av og kontekst rundt de ulike programmene (jfr Vabø 2006). Samtidig synes faglige spørsmål i relativt liten grad å dominere agendaen i de fleste av komiteene - et markant unntak her synes å være programkomiteen i NSK - og svært mange komiteer bruker møtene på mer administrativ saksbehandling og formelle beslutninger. Dette kan dels ha sammenheng med at dagens komitemedlemmer er en blanding av embedsmenn og fagpersoner, men og at programkomiteene møtes relativt sjelden, gjerne bare en gang i året. Med en slik møtefrekvens er det kanskje heller ikke rart engasjement og involvering varierer sterkt mellom komiteene, og at relativt få innstillinger fra hovedadministratorene blir endret av programkomiteene. Graden av samord- 
ning og kontakt mellom komiteene synes heller ikke å være stor. I programperioden så langt er det avholdt ett felles møte mellom alle komiteene.

Administratorene er sekretariat for de ulike komiteene, men samtidig er sekretariatet i København ansvarlig for kontakten med hovedkoordinatorer og hovedadministratorer (Konsortiet) (se Nordplus Common Programme Document 2008-2011). I realiteten betyr altså dette at komitéstrukturen nærmest er «frikoplet» fra kontakten med «eierne» i Nordisk ministerråds Sekretariat. At de personer som befolker de ulike komiteene i Nordplus familien ofte representerer de enkelte lands myndigheter (her er NSK et unntak), og således kan sies å veksle mellom å inneha en «styrende» og «kontrollerende» rolle, samt at mange også sitter i flere komiteer samtidig, er det ikke rart at mange aktører også er noe forvirret med hensyn til hvem som egentlig bestemmer i denne strukturen. Et typisk eksempel på den noe uklare styringsstrukturen er at kommunikasjonslinjene i Nordplus gjerne følger sin egen logikk, der ikke minst sekretariatet i København blir adressat og «overdommer» for spørsmål både av politisk og administrativ karakter. Rollen som hovedkoordinator synes også noe problematisk all den tid det formell beslutningsmyndighet ikke er tillagt SIU. Resultatet er dermed at man «koordinerer» mye uten at man kanskje er nærmere beslutninger som kan peke ut veien videre. Et typisk eksempel her er at hovedadministratorenes årsrapporter ikke automatisk også har gått til hovedkoordinator, men direkte til sekretariatet i København. I løpet av programperioden har det vært arrangert et eget seminar om styringsstrukturen, og selv om dette seminaret har bidratt til en større refleksjon rundt roller, ansvar og myndighet, synes en del av problemene fremdeles å være uløste. Her bør det gjøres forenklinger i styringsstrukturen som tydeliggjør ansvar, myndighet og kommunikasjonslinjer.

\subsection{Resultater og måloppnåelse}

Nordplus programmene har mange målsettinger knyttet til seg, der styrking av nordisk språk og kultur, innovasjon, kvalitet, og samarbeidsrelasjoner er de viktigste. Disse målsettingene er operasjonalisert gjennom de aktiviteter som Nordplus programmene støtter; mobilitet, nettverk og prosjekter.

Samtidig er Nordplus også et nordisk samarbeidsinitiativ hvor likeverdig deltakelse og utbytte også er sentralt for den langsiktige legitimiteten. Vurdert i et økonomisk perspektiv synes landenes innbetalinger og økonomisk “utbytte» av Nordplus å være noenlunde likt fordelt - om enn med noen nasjonale variasjoner. Landenes innbetaling til Nordplus er, som nevnt tidligere, knyttet opp mot BNI, og i tabell 8.3 vises en oversikt over tildelinger, innbetalinger i Nordplus rammeprogram på institusjonsnivå (basert på en beregning foretatt av SIU - SIU 2010c). Som tabellen viser vil BNP og populasjon gi en del variasjoner i hvor mye det enkelte land betaler inn til Nordplus. Tabellen viser først og fremst at Norge og Sverige er de land som i størst grad bidrar til rammeprogrammet sett i forhold til hvor mye de får 
tilbake. Generelt mottar Island og Finland mer programmidler enn hva som innbetales. Variasjonen mellom landene synes likevel ikke å være voldsomt stor, og hvis populasjon legges til grunn viser tabellen at eksempelvis Sverige, men også Litauen og Latvia mottar mindre enn hva landenes populasjon skulle tilsi. Siden fordelingseffektene av Nordplus varierer noe i forhold til hvilke kriterier som legges til grunn, kan det argumenteres med at dagens fordelingsnøkkel - som kombinerer ulike kriterier - er en hensiktsmessig måte å balansere ulike kjennetegn ved de nordiske og baltiske land.

Tabell 8.3 Oversikt over tildeling, innbetaling og populasjon for 2009 og 2010 i Nordplus rammeprogram.

\begin{tabular}{|c|c|c|c|c|c|c|c|c|}
\hline & $\begin{array}{r}\text { Antall } \\
\text { deltakende } \\
\text { inst. i } 2009\end{array}$ & Prosent & $\begin{array}{r}\text { Antall } \\
\text { deltakende } \\
\text { Inst. i } 2010\end{array}$ & Prosent & $\begin{array}{r}\text { Innbetalt } \\
\text { til Nord- } \\
\text { plus }\end{array}$ & Prosent & $\begin{array}{r}\text { Popula- } \\
\text { sjon }\end{array}$ & Prosent \\
\hline Danmark & 501 & 19 & 489 & 19,4 & $\begin{array}{r}13381 \\
184\end{array}$ & 20,4 & 5532579 & 17,3 \\
\hline Finland & 575 & 21,8 & 505 & 20,1 & $\begin{array}{r}10780 \\
134\end{array}$ & 16,4 & 5282346 & 16,5 \\
\hline Sverige & 605 & 23 & 538 & 21,4 & $\begin{array}{r}19660 \\
705\end{array}$ & 30 & 9047752 & 28,3 \\
\hline Island & 176 & 6,7 & 178 & 7,1 & 762228 & 1,2 & 299891 & 0,9 \\
\hline Norge & 463 & 17,6 & 430 & 17,1 & $\begin{array}{r}17440 \\
739\end{array}$ & 26,6 & 4640219 & 14,5 \\
\hline SUM Norden & 2320 & 88,1 & 2140 & 85 & 62025000 & 94,5 & 24802787 & 77,5 \\
\hline Estland & 121 & 4,6 & 144 & 5,7 & 927174 & 1,4 & 1332893 & 4,2 \\
\hline Litauen & 104 & 4 & 121 & 4,8 & $\begin{array}{r}1579 \\
283\end{array}$ & 2,4 & 3596617 & 11,2 \\
\hline Latvia & 87 & 3,3 & 113 & 4,5 & $\begin{array}{r}1103 \\
464\end{array}$ & 1,7 & 2291000 & 7,2 \\
\hline $\begin{array}{l}\text { SUM } \\
\text { Baltikum }\end{array}$ & 312 & 11,9 & 378 & 15 & $\begin{array}{r}3609 \\
921\end{array}$ & 5,5 & 7220510 & 22,5 \\
\hline $\begin{array}{l}\text { TOTAL } \\
\text { SUM }\end{array}$ & 2632 & 100 & 2518 & 100 & 65634921 & 100 & 32023297 & 100 \\
\hline
\end{tabular}

Kilde: SIU 2010c.

I forhold til vurderinger av økonomisk utbytte av Nordplus er det også viktig å understreke at det først og fremst ikke er landene som bør være den viktigste indikatoren på spredning, deltakelse og oppslutning, men antall deltakende institusjoner. Her viser tabell 8.4 at man i forhold til godkjente prosjekter i 2009 og 2010 finner en svært god spredning, og ikke minst et svært høyt antall institusjoner mer generelt.

Tabell 8.4. Antall deltakende institusjoner i godkjente prosjekter, fordelt på land

\begin{tabular}{lcc}
\hline & $\mathbf{2 0 0 9}$ & $\mathbf{2 0 1 0}$ \\
\hline Sverige & 605 & 538 \\
Finland & 562 & 493 \\
Norge & 463 & 430 \\
Danmark & 429 & 392 \\
Island & 176 & 178 \\
Estland & 121 & 144 \\
Litauen & 104 & 121 \\
Latvia & 87 & 113 \\
Færøyene & 49 & 56 \\
Grønland & 23 & 41 \\
Åland & 13 & 12 \\
\hline
\end{tabular}


Anlegger man et mobilitetsperspektiv knyttet til Nordplussamarbeidet finner man i hovedsak den samme store spredningen, og antall mobiliteter tyder da også på at selv om målsettinger som innovasjon og kvalitet over tid har blitt viktigere i Nordplussamarbeidet, er den tradisjonelle mobilitetsaktivitetene fremdeles sentral (se tabell 8.5).

Tabell 8.5. Mobilitet i 2010.

\begin{tabular}{|c|c|c|c|c|c|c|c|c|c|c|c|c|}
\hline \multirow[b]{2}{*}{$\begin{array}{l}\text { From } \\
\text { country }\end{array}$} & \multicolumn{12}{|c|}{ To country } \\
\hline & $A X$ & DK & EE & $\mathrm{FI}$ & $\mathrm{FO}$ & $\mathrm{GL}$ & IS & LT & LV & NO & SE & Total \\
\hline$A X$ & & 6 & 5 & 12 & & & 3 & 4 & 5 & 14 & 17 & 66 \\
\hline DK & 7 & 17 & 40 & 179 & 30 & 38 & 123 & 47 & 44 & 235 & 185 & 945 \\
\hline EE & 4 & 47 & 2 & 120 & 1 & 5 & 25 & 28 & 31 & 46 & 84 & 393 \\
\hline $\mathrm{FI}$ & 10 & 189 & 83 & 36 & 13 & 12 & 82 & 66 & 54 & 231 & 297 & 1073 \\
\hline FO & & 29 & 1 & 14 & 2 & 6 & 10 & 3 & 5 & 20 & 10 & 100 \\
\hline GL & & 33 & 2 & 4 & 8 & 2 & 10 & 2 & 3 & 14 & 14 & 92 \\
\hline IS & 6 & 109 & 21 & 65 & 13 & 10 & 8 & 23 & 29 & 97 & 73 & 454 \\
\hline LT & 3 & 64 & 31 & 79 & & 4 & 33 & 5 & 32 & 49 & 69 & 369 \\
\hline LV & 4 & 43 & 37 & 69 & 1 & 4 & 31 & 29 & 4 & 53 & 78 & 353 \\
\hline NO & 8 & 226 & 51 & 206 & 22 & 15 & 87 & 47 & 40 & 40 & 225 & 967 \\
\hline SE & 15 & 213 & 62 & 275 & 11 & 18 & 97 & 45 & 56 & 237 & 34 & 1063 \\
\hline Total & 57 & 976 & 335 & 1059 & 101 & 114 & 509 & 299 & 303 & 1036 & 1086 & 5875 \\
\hline
\end{tabular}

Kilde: SIU.

Tabellen viser ikke minst at Nordplus i høy grad bidrar til kulturell spredning gjennom at de personer som er mobile både kommer fra og reiser til hele det nordisk-baltiske området. Slik sett synes det i alle land og områder å være en relativt god balanse mellom utgående og inngående mobilitet. Innen dette generelle bildet er det som forventet at de fire største landene (Sverige, Danmark, Finland og Norge) både har mest av både den utgående og inngående mobiliteten. De baltiske land synes også å være godt integrert i Nordplusamarbeidet. Island har en noe spesiell profil sett i forhold til de fire andre nordiske landene, der landet er svært aktivt i noen programmer og mindre synlig i andre. For de selvstyrte områdene blir tallene små, men samtidig synes spredningen å være rimelig god.

Når det gjelder kvalitet og innovasjon, er dette forhold som det er vanskeligere å måle, men hvis man tar utgangspunkt i at en betingelse for innovasjon gjerne innebærer samarbeid mellom ulike typer aktører, har man flere indikasjoner på at Nordplusamarbeidet klarer å skape en arena hvor mangfold og samarbeid på tvers verdsettes.

I 2010 var eksempelvis Nordplus Voksen og Nordplus Horisontal de to programmer med størst organisatorisk mangfold når det gjelder koordinatorer. En opptelling viser at man i disse programmene i snitt har over et dusin ulike typer organisasjoner som koordinatorer. Sett i forhold til størrelsen på programmet, synes Høyere utdanning å være det program som har minst mangfold når det gjelder det organisatoriske mangfoldet blant koordinatorene. Slik sett kan man argumentere for at etableringen av Nordplus Horisontal har vært viktig for å fremme nytenkning rundt hvordan et Nordplustøttet prosjekt kan designes. 
Samtidig har man i inneværende programperiode også hatt ønsker om å legge noen innholdsmessige føringer på prosjektene gjennom årlige prioriteringer. I inneværende programperiode har den overordnede prioritering vært klimaspørsmål. Vurderer man nærmere hvilket gjenomslag denne prioriteringen har fått i de ulike programmene, synes det kun å være i junior at man kan finne en tydelig og markert respons. I Voksen, Høyere utdanning og Horisontal å være markert lavere. Ser man programmene under ett synes klimaprioriteringen derfor generelt ikke å ha skapt noen voldsom interesse. Intervjuer med ulike brukere i programmene indikerer at mange nok har en veldig pragmatisk holdning til den årlige prioriteringen, og at det både er en del forvirring rundt hvilken status prioriteringen har i forhold til andre mål i programmene, samt at en del brukere rett og slett ikke ønsker å utvikle eller har prosjekter hvor slike prioriteringer inkluderes. Det forhold at «klima» har vært en prioritering som har vært gjentatt over flere år synes også å skape et inntrykk av at man her nærmest søker å skape et nytt «virtuelt program» som går på tvers av den nåværende programstrukturen. I dag synes slike prioriteringer å bli brukt for å styrke den politiske relevansen av Nordplus. Det kan likevel stilles spørsmål ved om de årlige prioriteringene er hensiktsmessige redskaper for dette formål, og hvorvidt de bør videreføres i sin nåværende form.

\subsection{Integrering av de baltiske land}

Et generelt inntrykk fra intervjuene med brukere og administratorer er at integreringen av de baltiske land har vært veldig vellykket. For brukere i de baltiske land synes Nordplus å gi flere typer merverdi. For det første gir Nordplus konkret støtte til samarbeidsaktiviteter som synes sterkt ønsket fra baltisk side - knyttet til en genuin interesse for Norden, og til nordisk språk og kultur. For det andre har deltakelsen i Nordplus vært et skritt på veien mot en mer tydelig internasjonalisering - også utenfor det nordiske rom. For det tredje synes man på baltisk side også å ha blitt kjent med en annen måte å samarbeide på, kjennetegnet av en større grad av uformell kontakt og vekt på problemløsning, og der formaliteter, regler og rutiner kanskje ikke er så dominerende.

Som illustrert i tabell 8.5 er baltiske land godt integrert når det gjelder mobilitetsaktiviteter, og både når det gjelder inngående og utgående mobilitet. Ser man på deltakelsen per land i sin helhet i perioden 2008-2010 fremkommer det imidlertid et noe mer nyansert bilde når det gjelder integreringen av de baltiske land i utforming og organisering av prosjektene (se tabell 8.7 i vedlegg). Som vist i tabell 8.7 synes eksempelvis Litauen å markere seg tungt på koordinatorsiden i Voksen. Samtidig er Latvia og Estland mer betydelige aktører på koordinatorsiden i Horisontal. Ser man samlet på tallene, øker antallet partnere fra de baltiske land i programperioden sett under ett, og for Estland og Latvia øker også antall prosjekt hvor man er koordina- 
tor i denne perioden. Som tabell 8.6 viser er den samme tendens også tydelig når det gjelder baltisk deltakelse i de ulike rammeprogrammene som viser en økning i baltisk deltakelse fra 2009 til 2010.

Tabell 8.6: Nordiske og baltiske institusjoners deltakelse i rammeprogrammet i 2009 og 2010. Prosentandeler.

\begin{tabular}{lrrrrrrrr}
\hline & \multicolumn{2}{c}{ Høyere utdanning } & \multicolumn{2}{c}{ Voksen } & \multicolumn{2}{c}{ Horisontal } & \multicolumn{2}{c}{ Junior } \\
& $\mathbf{2 0 0 9}$ & $\mathbf{2 0 1 0}$ & $\mathbf{2 0 0 9}$ & $\mathbf{2 0 1 0}$ & $\mathbf{2 0 0 9}$ & $\mathbf{2 0 1 0}$ & $\mathbf{2 0 0 9}$ & $\mathbf{2 0 1 0}$ \\
\hline Norden & 91.2 & 89.5 & 76.9 & 70.7 & 74.3 & 72.6 & 80.1 & 76.1 \\
Baltikum & 8.8 & 10.5 & 23.1 & 29.3 & 25.7 & 27.4 & 19.9 & 23.9 \\
\hline
\end{tabular}

Også sett i et mer økonomisk perspektiv bør de baltiske land kunne si seg fornøyd med utbyttet fra Nordplus. En beregning som hovedkoordinator har foretatt ut fra tilgjengelige tall viser at de baltiske land generelt betaler inn mindre enn de får utbetalt i støtte via rammeprogrammet (SIU 2010c). Selv om beregningen er noe usikker grunnet mangler ved datagrunnlaget, synes situasjonen i 2009/2010 å ha vært at mens de nordiske land betaler inn rundt 95 prosent av midlene til Nordplus, mottar de i snitt rundt 86, 5 prosent av programmidlene. For de baltiske land er situasjonen at man betaler inn rundt 5 prosent av midlene, mens de mottar rundt 14,5 prosent av programmidlene (SIU 2010c). Samtidig viser analysen fra hovedkoordinator at de baltiske landene - i forhold til populasjonen - mottar mindre programmidler enn hva fordelingsmodellen skulle tilsi. At de baltiske land mottar mer enn de betaler inn, kan fortolkes langs ulike perspektiver. På den ene siden kan det argumenteres for at et samarbeid bør innebære at alle parter for noenlunde like mye ut av samarbeidet, og at det derfor bør tilstrebes relativt lik fordeling av ressursene i Nordplus. På den andre siden kan det også tenkes søkere fra de baltiske land utvikler gode søknader og prosjekter, og at kvalitet blir belønnet. Siden datagrunnlaget for analysen kun omhandler to år, bør man imidlertid avvente den videre utviklingen før det konkluderes omkring dette spørsmålet.

Men den baltiske deltakelsen i Nordplus har også medført utfordringer og mer uavklarte spørsmål. Tre forhold kan her nevnes avslutningsvis. For det første har deltakelse i Nordplus vært en mulighet for baltiske land til å delta i etablerte nettverksaktiviteter - noe som ifølge brukere i de nordiske land, har bidratt til refleksjon og nytenkning i relativt etablerte aktiviteter - men der hvor man fra baltiske side gjerne også ønsker å sette et tydeligere fingeravtrykk på innholdet i og utviklingen av Nordplus, der dette også handler om hva man fra baltisk side kan bringe inn i samarbeidet, og der man ønsker å komme bort fra en noe ensidig rolle som «mottaker». For det andre synes dagens økonomiske situasjon å ha bidratt til at egenandelskravet - spesielt $\mathrm{i}$ Junior - oppleves som vanskelig å imøtekomme. Spørsmål om økonomi og egenandeler har vært sentralt i integreringen av de baltiske land i Nordplusamarbeidet helt fra starten, og synes fremdeles å være et vanskelig tema. Her synes imidlertid en del brukere å være lite informert om de muligheter som finnes når det gjelder å oppfylle egenandelskravet gjennom egeninnsats 
m.m. Brukerne selv fremholdes imidlertid at det ved mange skoler ikke finnes «ledig tid» tilgjengelig for slike formål, og at dette er den fremste årsaken til hvorfor man velger mobilitet i stedet for prosjekter i dette programmet. Under dette punktet hører det også med at informasjonskontorene i Baltikum også har en del administrasjonsoppgaver som man til dels opplever som utfordrende å løse gitt de ressurser de har til rådighet. Selv om det ble gjennomført ulike opplæringstiltak og møter mellom hovedadministratorene og de baltiske informasjonskontorene, synes det fremdeles å råde en usikkerhet til hvilke oppgaver informasjonskontorene alltid skal gjøre. For det tredje synes spørsmål forbundet med språk å være en tilbakevendende utfordring for det baltisk-nordiske samarbeid. Dette går både på at baltiske deltakelse krever ressurser til oversettelse og i forhold til informasjonsspredning mer generelt, men punktet om språk er også viktig i forhold til NSK. I dag er de baltiske land ikke med i NSK, og dette synes å avstedkomme to typer reaksjoner fra baltiske side. Noen brukere ytrer klart ønske om at deres interesse for nordiske språk er så stor at man ønsker en mulighet til å delta også i dette programmet - på de vilkår som programmet i dag er tuftet på. Andre brukere ser på språkproblematikken som underordnet, og tenker seg at man heller bruker engelsk som hovedspråk, og der NSK burde utvides til også å inkludere baltisk kultur. De sistnevnte synspunkter indikerer at man fra baltisk side også stiller spørsmål ved, alternativt ikke er så bevisst en del av de grunnleggende mål med Nordplusprogrammene.

\subsection{Profilering og spredning}

Profilering av Nordplusprogrammene og spredning av resultatene fra prosjektene har over tid vært en utfordring i Nordplus. Også i tidligere programperioder har dette vært vurdert som noe som burde forbedres og som er viktig for å øke betydningen av Nordplus (Vabø 2006).

I forkant av lanseringen av Nordplus rammeprogram i 2008 ble det derfor satset mye ressurser og tid på markedsføring og informasjonsarbeid. Man arrangerte bl a egne «road shows» i samtlige land, og gjennomførte mer enn 30 informasjonsmøter. En egen web-side ble lansert, og det ble gjennomført koordinert annonsering og markedsføring. Både aktørene selv, og flere brukere påpeker at man her la listen høyt i forhold til profilering av det nye programmet. Utarbeidelsen av en egen grafisk profil for det nye rammeprogrammet må også sies å ha vært vellykket, og bidratt til å skape merverdi i form av enkel gjenkjenning og gjennomslag hos brukerne.

I de etterfølgende år har det årlig vært utarbeidet en informasjonsstrategi, men sett under ett synes innsatsen generelt å måtte karakteriseres som relativt fragmentert. I 2010 synes dessverre profilering og spredning derfor fremdeles å være et område hvor det ikke foregår en koordinert innsats, og hvor de initiativer som ble tatt i 2008 ikke systematisk har blitt fulgt opp. Dette betyr ikke at man i nåværende programperiode ikke har gjennomført 
aktiviteter for å styrke profileringen og resultatspredningen. Typiske aktiviteter som har vært gjennomført er konferanser og seminarer i regi av de ulike hovedadministratorene, utdeling av brosjyrer til ulike potensielle brukergrupper, samt formidling og oppdatering av hjemmesidene for Nordplus.

Brukerne synes generelt at hjemmesidene til Nordplus er ryddige, oversiktelige og tiltalende, men at de har mer karakter av å være et sted for informasjonsinnhenting enn for dialog og erfaringsutveksling. Selv om det $\mathrm{i}$ de fleste programmer er linker og opplysninger om beste-praksis prosjekter, kan man som utenforstående nettleser i liten grad finne informasjon om profilen på andre prosjekter som løper, hvilke institusjoner som deltar i ulike aktiviteter, og hva resultatene har vært. Oppdateringen av sidene foregår uregelmessig, og dette medvirker til mange brukere ikke oppsøker hjemmesidene fordi de «vet at de ikke skjer noe der».

I utgangspunktet har hovedkoordinator et overordnet ansvar for hjemmesidene, men oppgir at man grunnet kapasitetsproblemer, ikke klart å utvikle disse tjenestene som ønskelig. Dette henger delvis sammen med funksjonaliteten til ARS (se under) der dette systemet ikke har klart å generere informasjon og analyser som også kunne ha vært verdifullt å formidle både til nåværende brukere, men også til eksterne interessenter. At ARS har medført mye ekstraarbeid, og at dette har tatt ressurser fra andre oppgaver nevnes også som en viktig årsak. Når det er sagt er ikke dagens situasjon et resultat av ARS alene. I dag synes ikke minst oppdatert informasjon om de løpende prosjektene å være vanskelig tilgjengelig. Det er utvilsomt hensiktsmessig at hjemmesidene oppleves relevante for brukerne, men i dag synes webportalen å ha for stort fokus på dette i forhold til andre som enten bare er nysgjerrige på Nordplus, eller som ønsker å lære av de prosjekter som er i gang.

Selv om en del brukere har utviklet egne hjemmesider for prosjektene er det til dels vanskelig å elektronisk «spore opp» mange av de prosjekter som har fått Nordplustøtte i inneværende periode. At «inngangen» til slike prosjektsider ikke alltid kan finnes på dagens programsider gjør det vanskelig å finne konkrete eksempler på hvordan prosjektene fungerer i praksis.

Hvis man søker etter Nordplus hos de ulike hovedadministratorene og informasjonskontorene er også det veldig varierende hvor enkelt det er å kople seg opp til Nordplusprogrammene. Her er det både ulik lay-out og ulike nivåer på de aktuelle lenkene. Mangel på systematikk og koordinering gir derfor et noe kaotisk inntrykk av Nordplus sett utenfra, og standarden her er ikke som man bør kunne forvente av et program som er såpass stort og omfattende.

Sammenlignet med LLP synes Nordplus fremdeles å ha en relativt gunstig profil. Selv om mange brukere oppfatter at Nordplus er blitt mer «byråkratisk» over tid, ikke minst ved at man har begynt å praktisere regler og rutiner strengere, synes de fleste likevel å være enige i at Nordplus har mange fordeler sammenlignet med EUs LLP programmer. Et typisk eksempel her kan være de regler som nylig ble spesifisert knyttet til for sent leverte 
søknader til Nordplus-systemet, der disse reglene fremdeles åpner for et rimelig stort innslag av skjønn.

Av de ting som nevnes som bidrag til stor grad av fleksibilitet er for det første de lave tersklene for kontakt ved at språkproblemer minimeres gjennom at problemer løses nasjonalt. For det andre at nettverkene som er etablert er basert på gjensidig tillit og som ofte er opparbeidet over flere år. For det tredje at reglene og rapporteringen fremdeles er færre og enklere i Nordplus. Samtidig synes EUs programmer i en del tilfeller å ha bedre finansiell støtte enn Nordplus kan tilby, samt at mulighetene til å delta i større og enda mer internasjonale nettverk selvfølgelig taler til LLP programmenes fordel.

Hovedadministratorene oppfatter generelt ikke konkurransen fra LLP som noe problem, snarere hevdes det at LLP og Nordplus ofte markedsføres i felleskap, og at begge type programmer tjener på dette. Signalet som gis er at markedet er stort nok for både LLP og Nordplus. Når det er sagt, bør det imidlertid også nevnes at det faktum at ekspressmobilitet øker i Nordplus kan være knyttet til at dette er noe som LLP programmene ikke tilbyr, og som kan indikere at det å markere seg som noe forskjellig fra EUs programmer kan være fordelaktig.

\subsection{Administrasjon av programmene}

Som antydet over er styringsstrukturen i Nordplus forholdsvis komplisert. På den bakgrunn er det således kanskje overraskende å konstatere at selve administrasjonen av Nordplusprogrammene foregår forholdsvis problemfritt når det gjelder søknadsbehandling, drifting av de ulike programmer, og administratorenes evne til praktisk problemløsning.

Det er flere forhold som medvirker til dette resultatet. For det første har hovedadministratorene god kompetanse og erfaring med Nordplus (selv om det er programkomiteene som sitter med den formelle beslutningskompetansen), og på vurdering av søknader til programmene. For det andre er Nordplus slik strukturen er i dag forholdsvis identisk med EUs LLP programmer, og denne sammenfallende programorganiseringen gjør at både brukere og administratorer føler de kjenner logikken i Nordplus selv om det også er en del forskjeller mellom Nordplus og EUs LLP programmer når det gjelder støttekriterier og regler. For det tredje synes det å være etablert en kultur for samarbeid og uformell håndtering av problemer som måtte oppstå internt i konsortiet - der problemer i den formelle styringsstrukturen løses uformelt. For det fjerde gjorde man flere gode grep i oppstarten av det nye programmet som har bidratt til større grad av profesjonalisering av de administrative prosessene. Gjennom utviklingen av «Nordplus Common Programme Document» og en egen håndbok for søkere som oppdateres og som er elektronisk tilgjengelig, har man fått utviklet en del standarder og rutiner for saksbehandlingen som både administratorer og til dels brukere finner verdifulle. 
Ser man på ressursrammene for de ulike programmer (se tabell 8.8 i vedlegg), og antall søknader sett i forhold til de innvilgende prosjekter, er bildet at man i Horisontal og Voksen generelt i programperioden har en høyere avslagsprosent enn for Høyere utdanning, NSK og Junior. Sett i forhold til hva både hovedadministratorene selv rapporterer, oppleves ressursknapphet ikke som et stort problem i alle programmer (jfr Horisontal, Junior og NSK), og slik sett synes det ikke å være en markert sammenheng mellom ressursrammer og avslagsprosent.

Det er imidlertid også andre utfordringer på den administrative siden. Det forhold at Nordplusprogrammene er ulike størrelsesmessig medfører at hovedadministratorenes saksbehandling varierer mye i omfang. Her synes det ikke å være et optimalt samsvar mellom de ressurser som tildeles hovedadministratorene, og de arbeidsbelastninger disse har. Ikke minst synes dette å være en utfordring for Høyere utdanning. En del administrative ressurser synes å bli tildelt på bakgrunn av tradisjon og historie, men siden Nordplusprogrammene synes å være i endring, kan nye prinsipper for ressursfordeling være et spørsmål som bør opp til vurdering. Dette gjelder også ressurser som tildeles hovedkoordinator. I dag synes ikke ressursene som går til hovedkoordinator å være tilstrekkelige til at profilering, markedsføring og analyse av Nordplus ivaretas på en god måte. Den ressurs som er tildelt rapporteres i all hovedsak å gå til drift.

Disse problemene synes i stor grad å henge sammen med dagens styringsstruktur i Nordplus, og slik sett vil en re-designet fremtidig styringsstruktur ha store implikasjoner for administrasjonen og driften av Nordplus. Her er imidlertid alternativene flere, noe som vi vil komme tilbake til i siste kapittel.

\subsection{ARS}

De fleste av hovedadministratorene har det synspunkt at dagens ressurser til administrasjon er for begrenset. Dette synes å henge nært sammen med den manglende funksjonaliteten til ARS. Tanken bak å ha en elektronisk programportal som kan håndtere ulike funksjoner herunder både søknader, informasjon, og analyse, er god og noe både brukere og administratorer er positive til.

ARS er i utgangspunkt designet i ulike moduler for søkning, administrering, og statistikk/analyse. Generelt har ARS også hatt store driftsmessige problemer i programperioden med samtlige moduler, spesielt i oppstartsfasen hvor hele systemet nærmest kollapset, og hvor et eget re-utviklings- og re-testingsprosjekt måtte igangsettes. Sett i etterkant ble dette systemet lansert i 2008 uten at det verken var tilstrekkelig godt spesifisert og designet, teknisk fungerende, eller kvalitetssikret fra et brukerperspektiv. Ikke minst synes dette å ha vært et problem for Junior der søkerne ikke alltid har den kompetanse og erfaring som trengs for å jobbe opp mot slike elektroniske 
søknadsportaler, og hvor brukervennligheten også har vært forholdsvis lav (lett å fylle ut feil felt i søknadskjemaet, etc).

I 2010 fungerer imidlertid ARS tilfredsstillende når det gjelder søknadsprosessen, og administrasjonen av søknadene, og selv om en del brukere mener at systemet fremdeles lider under en del tekniske feil, opplever majoriteten at systemet ikke er spesielt vanskelig å bruke. Hovedproblemet i dag er først og fremst at analyse og statistikkdelen ikke fungerer godt. Selv om en del standardrapporter er definert i systemet, synes problemet å ha sin bakgrunn $i$ at den opprinnelige kravspesifikasjonen var ufullstendig og lite relevant for de analyser man har behov for i Nordplus. Et eksempel på tungvinte arbeidsprosesser er at søknader fra ARS må konverteres til excel-filer før forholdsvis enkle analyser og systematiseringer kan gjøres. Dette betyr i klartekst at en del grunnlagsdata blir lagt inn på en slik måte at de ikke kan koples sammen og relateres til hverandre. Også historiske data synes vanskelig å få frem (eksempelvis knyttet til hvilken forhistorie ulike prosjekter og nettverk har), og endringer i systemet er vanskelig å implementere. Den desentraliserte administrasjonsordningen i Nordplus bidrar her til å skape ytterligere problemer da IKT-kompetansen hos hovedadministratørene er høyst varierende, og der teknisk support dermed må ta over telefon eller mail. Sammen skaper dette den effekt at den kan bli vanskelig for de hovedadministratorer som har mange søknader å ferdigstille saksbehandlingen på en kvalitetsmessig god måte innen de frister som er satt.

Det bør bemerkes at leverandør av systemet har hatt store personellutskiftninger i programperioden, og der det kan være sterke indikasjoner på at man ikke har fått den oppfølging og service man burde forvente fra leverandøren. I tillegg synes man heller ikke å ha hatt god IKT-kompetanse hos hovedkoordinator, og med begrenset kapasitet for å følge opp ARS har dette medført at forbedringer har tatt svært lang tid.

En ytterligere kompliserende faktor som kan bidra til å forklare problemene ved ARS er at Sekretariatet i København i programperioden har hatt det formelle ansvaret for systemet. Selv om sekretariatet aktivt har forsøkt å koordinere utviklingsarbeidet med ARS kan man likevel se at denne løsningen ikke har vært ideell for å utvikle større grad av brukerorientering og hensiktsmessighet. Sentrale problemer her er at Sekretariatet i liten grad har hatt praktisk brukererfaring med systemet, samt at hovedadministratorene ikke har fått et eierskap til systemet ved at det formelle ansvaret for videreutvikling formelt har ligget i København. Denne mangelen på styringskapasitet og brukerkompetanse (regelfortolkning, etc.) er viktige stikkord som kan forklare at ARS fremdeles er noe dysfunksjonelt analysemessig. En indikasjon på dette er at det i 2010 er første gang alle hovedadministratorer har kjørt saksbehandling i ARS.

I prinsippet foreligger det to valgmuligheter med ARS: enten forkaste dagens system og starte på nytt, eller å videreutvikle ARS. Hvorvidt dette er to reelle valgmuligheter er imidlertid et annet spørsmål. En utfordring med ARS er at man i 2010 har brukt så mye tid og ressurser på systemet at «ta- 
pene» knyttet til å starte pånytt ville bli uforholdsmessig store. Hvis man beholder ARS vil det imidlertid bety at ikke alle typer programendringer reelt sett er mulig fremover, og at ARS dermed i realiteten vil legge føringer for Nordplus, og ikke omvendt. Samtidig er det også store risiki knyttet til å forkaste ARS, og starte med et nytt system. All systemutvikling av denne typen innebærer relativt store omkostninger og man vet i liten grad om et eventuelt nytt system - relativt sett - ville fungere bedre. For brukerne som i de siste årene har vendt seg til å bruke ARS - ville et nytt system også medføre at de må gjennom en ny «innlæringsprosess». Selv om ARS altså har flere svakheter i den nåværende versjon er det mye som tilsier at fortsatt utvikling av systemet - iallefall i en 3-5 års periode - er veien å gå.

NIFU er kjent med at det har pågått et løpende utviklingsarbeid med ARS, hvor man i fellesskap forsøker å finne gode løsninger på de utfordringer systemet har skapt. Spørsmålet er om dagens styringsstruktur sikrer et kontinuerlig fokus på dette arbeidet hvis man ikke gjør noen grep knyttet til formelt ansvar for videreutvikling av systemet. Det er grunn til å tro at en bedret styring av utviklingsarbeidet, tett koplet med god innsikt i funksjonalitetet til ARS, fremdeles kan skape forbedringsmuligheter på analyse og resultatindikatorsiden. 



\section{Videreutvikling av Nordplus - en drøfting}

Evalueringen av Nordplus har gitt sterke indikasjoner på at Nordplus er å regne som en vel fundert institusjon i det nordiske rom. Både søkere, brukere, administratorer, komitemedlemmer og ulike interessenter har gitt klart uttrykk for at Nordplus er en aktivitet som er verdifull. Den gir merverdi og har en eksistensberettigelse gjennom de temaer som adresseres.

Når det er sagt er det imidlertid mer uenighet om i hvilken retning Nordplus bør utvikle seg i årene som kommer. Synspunktene som er fremmet spenner her vidt og forslagene er til dels mangfoldige. Basert på de intervjuer som er foretatt, evalueringens resultater og hvordan Nordplus programmene faktisk synes å ha utviklet seg i perioden fra 2008 og frem til i dag, ønsker NIFU å bidra til en mer prinsipiell diskusjon omkring utformingen av Nordplus ved å skissere tre noe forskjellige veier videre for programmet basert på stikkordene; Konsolidering, Konsentrasjon og Koordinering. Dette er tre scenarier som tar utgangspunkt $i$ de spenningene som en innebygget $i$ Nordplus og som ble skissert i kapittel 1 (se figur 1), og handler om hvordan man kan håndtere disse spenningene. Som antydet er konsolideringsscenariet basert på at gamle og nye formål med Nordplus er noe man må leve med, der det viktigste er å justere styringen av rammeprogrammet, samt gjøre mindre justeringer i programinndeling. Konsentrasjonsscenariet argumenterer imidlertid mer for at spenninger over tid kan være ødeleggende for fokus og gjennomslag for programmene, og at veksten og den økte kompleksiteten i programmene må håndteres gjennom en sterkere prioritering i programmene og der en også vurderer programstrukturen mer kritisk, enten i forhold til målgrupper, virkemidler eller i kombinasjoner av dette. Koordineringsscenariet kan på sin side sies å være svaret på den økte oppmerksomhet utdanningsspørsmål etter hvert har fått i Norden, og behovet for økt profesjonalitet rundt håndteringen av slike spørsmål. I dette perspektivet ser man dermed på utviklingstrekk også utenfor Nordplus, men som kan ha betydning for hvorvidt dagens programorganisering er den mest hensiktsmessige måten å håndtere disse på.

I tillegg til å identifisere argumentene for de ulike veiene, har vi også antydet noen av de endringer (i form av anbefalinger) som vi mener kan høre til de ulike alternativene. Naturlig nok har NIFU flest anbefalinger knyttet til Konsolideringscenariet som innebærer færrest endringer i forhold til dagens programorganisering, og der anbefalingene blir mer generelle i forhold til de to andre scenariene som er utledet. 


\subsection{Konsolidering}

Evalueringen har avdekket at Nordplus er et rimelig velfungerende program, og at selv om attraktiviteten synes noe minsket, er programmet fremdeles regnet for å være et viktig instrument for å fremme nordisk språk, kultur, og samarbeid knyttet til utdanning og formidling av denne. Man kan derfor argumentere for at Nordplus først og fremst trenger å konsolidere dagens programstruktur og organisering, der de problemer som er avdekket søkes løst, og der man strømlinjeformer de programmer som allerede eksisterer.

Andre argumenter for konsolidering er at Nordplus har vært gjennom en rekke endringer i inneværende programperiode (herunder innføring av ARS, etableringen av Horisontal, inkluderingen av de baltiske land, samt omleggingen av språkarbeidet i Nordisk ministerråd), og at en endring av programmene bare bidrar til å skape nye problemer fremfor å løse de eksisterende.

Tidsaspektet er også viktig i et konsolideringsperspektiv. Man kan hevde at dagens programperiode er for kort i forhold til å kunne nå de ambisiøse mål som er satt, og at en lengre programperiode burde kunne gi større langsiktighet og bedre planleggingshorisonten for både brukere og administratorer. En mulighet er her å forlenge dagens programperiode, eksempelvis til fem år.

I tillegg kan man også argumentere for at dagens organisering av Nordplus i seg selv er et eksempel på nordisk samarbeid gjennom modellen med hoved- og medadministratorer, og at denne desentraliserte modellen skaper lave terskler for kontakt både innen og mellom de ulike landene som er involvert. At antallet prosjekter som blir støttet gjennom Nordplus har er høyt og endatil økende kan også ses som et tegn på at programmet i dagens form i høy grad svarer på ulike behov hos et stort antall brukerne.

Evalueringen har påvist at selv innenfor dagens programstruktur og organisering er det behov for visse justeringer og forbedringer. Selv om at en viss overlapp mellom programmene kan ses som fordelaktig og bidra til mangfold innen visse typer aktiviteter og målgrupper, er en for stor grad av overlapp uheldig i og med at man i mindre grad får sammenlignet og sett tilgrensende søknader i sammenheng, og der fragmentering heller enn samordning kjennetegner aktivitetene både innen og mellom programmene. Her bør man finne en avklaring i forhold til Voksen og Horisontal, Høyere utdanning og Horisontal, samt mellom Junior og NSK. Et viktig anliggende i denne forbindelse er en tydelig avklaring av formålet med Horisontal - skal dette programmet være et selvstendig program med en selvstendig profil, eller et slags «paraplyprogram» for søknader som ikke passer inn i de mer etablerte programmene? Gitt det mangfold og de muligheter som allerede eksisterer innenfor dagens programstruktur, kan det argumenteres for at Horisontal bør styrke sin selvstendige profil i større grad, kanskje endatil at man i større grad spesifiserer fra programmets side hva slags type prosjekter man ønsker, og hvordan disse kan organiseres.

Det siste antyder at styringsstrukturen i Nordplus Horisontal bør bli tydeligere, men det er et punkt som gjelder samtlige programmer i Nordplus 
familien. Evalueringen har vist at Nordplus har en styringsstruktur som de aller fleste opplever som uklar og tungvint, om enn med stor legitimitet. Hovedadministratorene har en tydelig oppgave i dagens struktur og deres funksjon kan opprettholdes. Samtidig synes rollene mer uklare rundt ansvaret og rollene til programkomiteene og hovedkoordinator. Hvis man skal vurdere disse to aktørene i forhold til det som fremstår som utfordringer i Nordplus, er en tydeligere styringsstruktur, mer konsentrert aktivitet knyttet til profilering, markedsføring og analyse kanskje det aller viktigste.

I praksis kunne dette bety at dagens programstruktur forenkles ved at alle programmer kun forholder seg til en felles komite i stedet for fem, men der representanter i denne komiteen gjerne har et spesielt ansvar for ulike delprogrammer i Nordplus familien. Det kan også vurderes om man ikke bør profesjonalisere ledelsen av denne komiteen gjennom å ha en «arbeidende programleder» som både leder programkomiteen og som har det overordnede ansvaret for driften av alle programmer i Nordplus. Medlemmene i komiteen bør for øvrig både ha stor faglig tyngde og innsikt i ulike dimensjoner med Nordplusamarbeidet slik at programmene og deres profil blir sett $\mathrm{i}$ sammenheng. For å sikre faglig input i søknadsarbeidet kan hovedadministratorene i større grad trekke veksler på ulike ressurs- og fagpersoner i de innholdsmessige vurderingene av søknadene. I tillegg synes det påkrevet å se til at rollene og ansvarsfordelingen mellom EK-U og Nordplus Hovedkomite ikke overlapper.

I forhold til hovedkoordinatorjobben bør ansvaret for kontakten med Ministerrådets sekretariat overtas av den «arbeidende programlederen» som i større grad kan trekke veksler på hovedkoordinator til analyse, profilering, utrednings- og formidlingsarbeid slik at dette området kan få et løft. Sett i forhold til ARS bør ansvaret for utviklingen og driften av dette programmet legges til hovedkoordinator, men med en arbeidende programleder som den formelle leder. En slik styrings- og organiseringsmodell ville gi en tydeligere ansvars- og rollefordeling mellom sekretariatet i København, dagens hovedkomite og dagens hovedkoordinator.

Ut fra en konsolideringstankegang, og ut fra signaler fra mange administratorer, brukere og representanter fra de baltiske land, kan det også være hensiktsmessig å inkludere NSK i dagens rammeprogramstruktur. Dette ville innebære en åpning av NSK i forhold til Baltikum, men der målsettingen med programmet ville være uendret. Dette betyr at de nordiske språkene fremdeles ville prioriteres i samarbeidet med der brukere fra baltiske land med en interesse for nordiske språk kunne koples til pågående prosjekter i Norden.

Et viktig anliggende i et konsolideringsperspektiv er også at det bør ryddes noe opp i de mange målhierarkier, resultatambisjoner, årlige prioriteringer og føringer som Nordplus programmene i dag er kjennetegnet av. Selv om slike konkretiseringer er ment å fungere som styringsvirkemidler er omfanget av dem i dag så stort at det kan stilles spørsmål ved om de samlet gir den retning og profil som ønskelig. 
Til sist bør det gjøres en systematisk og kontinuerlig innsats for å styrke profilering, informasjon og markedsføring. Her bør det meste av denne innsatsen knyttes til å aktivere dagens webportal, og der muligheten for interaktivitet, læring og informasjon om resultater styrkes. En egen stilling som webredaktør bør opprettes, og egne ressurser knyttes til drift og utvikling.

Oppsummert vil hovedanbefalingene i forhold til dette perspektivet derfor kunne konkretiseres som følger:

- Dagens programstruktur beholdes, men overlappinger forsøkes eliminert gjennom en omfordeling av noen konkrete aktiviteter mellom programmene.

- Dagens programperiode forlenges, eksempelvis til fem år.

- Organiseringen med hoved- og medadministratorer beholdes, men programstrukturen forenkles gjennom kun å ha en felles programkomite, men der enkeltmedlemmene har et spesielt ansvar for ulike delprogram.

- Det utnevnes en «arbeidende programleder» av en ny hovedkomite som vil ha det overordnede ansvaret for løpende utvikling og drift av programmet.

- «Arbeidende programleder» vil ha hovedansvar for Nordplus i forhold til sekretariatet i København, og vil kunne bruke hovedkoordinator som instrument for å styrke analyse, profilering og videreutvikling av Nordplus.

- Ansvaret for ARS overføres fra Sekretariatet i København til hovedkoordinator for Nordplus.

- NSK inkluderes som en del av rammeprogrammet, men med uendrede målsettinger og fokus. De baltiske land vil dermed inkluderes i dette programmet.

- Det bør gjøres en målrettet satsing på dagens webportal for å aktivere denne som et mer dynamisk redskap i profileringen av Nordplus. En egen stilling som webredaktør bør vurderes.

- Det etableres et garantifond slik at man kan tildele litt mer enn tildelte ressurser hvert år, og på denne måten ta høyde for å håndtere problemstillingen med ubrukte midler innenfor programperioden.

I tillegg bør følgende mer detaljerte anbefalinger vurderes:

\section{Horisontal:}

- Horisontal bør sterkere markedsføres som et selvstendig program, og ikke som et «restprogram» i Nordplus.

- Det bør avklares hvordan dagens overlapping med Voksen og Høyere utdanning skal håndteres.

- Gitt størrelsen på programmet bør hovedadministrator styrke kontakten mellom de ulike prosjektene for derigjennom synliggjøre programmet bedre eksternt. 
- Programkomiteen bør styrke involveringen i Horisontal, og bidra mer aktivt i utformingen av programmet.

\section{Høyere utdanning:}

- Ressursrammen til Høyere utdanning synes noe liten gitt interessen for programmet, alternativt bør hovedadministrator selektere prosjektene strengere.

- Hovedadministrator bør analysere nærmere de historiske føringene knyttet til prosjektene, og kritisk vurdere graden av nytenkning og innovasjon i prosjektporteføljen - dette kan ha stor betydning i forhold til å effektivisere saksbehandling i de årlige søkerrundene.

- Resultatene fra prosjektene bør synliggjøres bedre, og informasjonen bør være lett tilgjengelig for eksterne brukere.

- Programmet bør styrke sin profil som «komplementært» i forhold til EUs LLP programmer, og bør markedsføre sine unike kjennetegn sterkere.

Junior:

- Kravet til samarbeid i utviklingsprosjekter og tematiske nettverk gjelder to land (ikke som nå tre land), da dette synes å være mer overkommelig og kan gi rom for flere aktivitetskombinasjoner (for eksempel mobilitet og utviklingsprosjekt).

- Sette et tak for enkelttildelingene i stedet for flat nedskjæring, slik at søkerne kjenner de økonomiske rammene når de søker.

- Tidligere søknadsfrist/tildeling om våren for å kunne forberede aktiviteten neste skoleår.

- Gi tilskudd til kost og losji for elevene i mobilitetsdelen, da det ikke er realistisk at de kan bo privat.

- For at midlene skal bi brukt opp, kan tildelingen disponeres over to skoleår (som i Comenius-programmet), og bli utbetalt som en rundsum til hver skole i stedet for som nå, differensierte beløp.

- Nordplus rammeprogram initierer diskusjon om behovet for koordinatorer for internasjonalt arbeid på skoleeiernivå.

- Arrangere kontakt- og søkeseminarer som kan bidra til rekruttering og opplæring av nye søkere.

Voksen:

- Tydeliggjøring og forenkling av regelverket.

- Tydeliggjøring av forskjellene mellom aktivitetstypene.

- Tidligere søknadsfrist/tildeling om våren for å kunne forberede aktiviteten neste skoleår.

- Sette et maksimumsbeløp for de forskjellige aktivitetstyper slik at søkerne kjenner de økonomiske rammene når de søker.

- De baltiske landenes deltagere i Nordplus Voksen er avhengige av at bevilgningen utbetales til avtalt tid. 
- Fortsette (ekspandere) aktiviteten angående kontakt- og skriveseminarer som kan bidra til rekruttering og opplæring av nye søkere.

- Styrke synliggjøringen av voksenopplæring som en viktig oppgave at dagens unge er morgendagens voksne og vil trenge aktører som tilbyr utdanningsmuligheter.

NSK:

- NSK klargjør sine årlige prioriterte mål for programmet.

- Nordplus språk drøfter vektleggingen mellom strategier for nordiske språk og for de skandinaviske språk i sine strategier og handlingsplaner.

- NSK klargjør for betydningen av begrepet «kultur» og hva det innebærer for videreutviklingen av programmet nordisk språk og kultur.

- NSK åpnes for søknader fra baltiske land for emner som gjelder innlæring og praktisering av nordiske språk og forskning og utviklingsarbeid på nordiske - baltiske språk, for eksempel oversettelser og ordboksarbeid.

- Søknadsfristen til NSK, 1. mars flyttes bakover til 1. februar for å gjøre det enklere for søkere under mobilitetsdelen (skoler) å planlegge aktiviteten neste skoleår.

\subsection{Konsentrering}

Evalueringen har imidlertid også avdekket at Nordplus programmene er i ferd med å endre seg der dette også kan hevdes å være et uttrykk for at brukerbehovene er i endring. Historien om Nordplus programmene er på mange måter en historie om vekst og ekspansjon, og der ekspansjonen både i hele programporteføljen (økning i antall), og innen det enkelte program (økning i type prosjekter og aktiviteter innen programmene). Etableringen av Horisontal kan i et slikt perspektiv ses på som et forsøk på å skape et nytt samordningsnivå på noe som er blitt for stort og fragmentert.

Et annet argument for større grad av konsentrering er knyttet til at spredningen av ressurser på et stort antall prosjekter bidrar til mindre oppfølging av det enkelte prosjekt, samt at det er vanskeligere å se de samlede resultater av programmene. Dagens økonomiske situasjon i de nordiske land kan også tilsi at Nordplus neppe vil motta en sterk økning i ressursene i årene som kommer, og at den ekspansjonen som Nordplus har vært gjennom på et eller annet tidspunkt må resultere i en sterkere prioritering og konsentrasjon av eksisterende ressurser. En konsentrasjon ville også potensielt kunne bidra til at Nordplus ble enklere og markedsføre og profilere, og der man tydeligere kunne se merverdien for Norden.

På samme måte som at tidsaspektet for programmet er en faktor som kan bidra til konsolidering, kan et lengre tidsaspekt også være gunstig i forhold 
til større grad av konsentrasjon. En lengre programperiode kan eksempelvis åpne for sterkere prioriteringer av visse mål innen perioden.

I dag omfatter Nordplus en rekke ulike programmer og aktiviteter innen disse programmene herunder tradisjonelle mobilitetsaktiviteter, utviklingsprosjekter innen og på tvers av sektorer, felles studieprogrammer m.m. Et markant trekk, som til dels også har vært avspeilet i det inneværende program, er at man har ønsket å dreie aktiviteten bort fra mobilitet til utviklings- og fellesprosjekter der mobilitet eventuelt er innebygget i det prosjekt som gjennomføres. Ser man på utviklingen i Nordplus Høyere utdanning det største programmet - viser tallene at tradisjonell mobilitet knyttet til studentutveksling er på vei nedover, mens såkalt ekspressmobilitet er på vei opp. Denne utviklingen kan både skyldes mer generøse støtteordninger innen konkurrerende programmer, men også at tradisjonell mobilitet i seg selv kanskje ikke har den samme attraktivitet som tidligere. Ikke minst kan man identifisere en sterkere resultatorientering der flere brukere indikerer at studentene i dag gjerne vil ha konkret utelling for de aktiviteter de er involvert $i$, og at utveksling uten et sterkt innhold og et konkret resultat ikke lenger synes like attraktivt.

En utviklingsvei som vektlegger større grad av konsentrasjon kan organiseres på ulike måter. Samtidig vil man også i dette scenariet ha behov for en tydeligere styringsstruktur, der mange av de anbefalinger som ble gjort gjeldende i Konsolideringsscenariet også bør vurderes. Hovedpoenget er imidlertid at man bør se på programstrukturen og prioriteringene internt i programmene med nye øyne. Her kan man enten tenke seg at dagens programmer har et sterkere fokus på enkelte aktiviteter, eller at dagens programstruktur endres. Hvilken løsning som velges her avhenger til dels av hva som er enkelt å få til - eksempelvis uten at ARS trenger dramatisk remodellering - og hva som ønskes prioritert i en sterkere konsentrert satsing. Som i det forrige scenariet synes det også her å være fornuftig at ansvaret for ARS gis til den aktør som i det daglige har koordineringsansvaret.

I forhold til det sistnevnte poenget kan et startpunkt være at man mer prinsipielt diskuterer hvorvidt dagens ressursrammer i det enkelte program er tilpasset de politiske målsettinger man har med Nordplus. Programmenes ulike størrelse og aktivitetsnivå henger til dels sammen med hva som tradisjonelt har vært etterspurt og en utvikling der de ulike programmene har «vokst frem» mer naturlig. Kanskje er tidspunktet inne for å markere mer overordnede politiske prioriteringer i det nordiske rom, og der reallokeringer mellom programmene og en sterkere satsing på og profilering av enkelte aktiviteter innen programmene er et mulig utfall?

Et element i en slik debatt er om Nordplus fortsatt skal være forholdsvis likt EUs LLP programmer, eller om man sterkere skal markere at Nordplus er et nordisk program - med en tydelig nordisk profil. Hvis det siste er alternativet bør en større grad av konsentrasjon skje på de områder der hvor man kan være annerledes. En slik mulighet kan være den sterke interessen for ekspressmobilitet og utveksling innenfor en tidshorisont på en måned. 
En annen mulighet er å se på muligheten for å styrke programmer som Horisontal gjennom å se dem i sammenheng med eksempelvis Voksen, og deler av porteføljen i Høyere utdanning for derigjennom å skape et nytt tungt program som skal være sektoroverskridende og fokusert på at grenseflatene mellom utdanningssektorer synes å bli bygget ned. En tredje mulighet - som etterlyst fra en del brukere og også fra Baltikum - å etablere et eget kulturprogram atskilt fra dagens NSK. Her bør man imidlertid være klar over at det allerede eksisterer et kulturprogram utenfor Nordplus programmene. At man i det nordiske samarbeidet opererer med to forskjellige kulturprogrammer synes svært uhensiktsmessig, og noe som ikke taler for en slik løsning.

I tillegg er det også mulig at man i stedet for årlige prioriteringer på forskjellige tema, reserverer egne Nordplus program til slike aktiviteter, der mulighetene til nettverkssamarbeid og samspillseffekter mellom ulike prosjekter sannsynligvis er større enn hvis prioriteringer spres på ulike program. Gjennom NSK har man på mange måter allerede en slik satsing, og slik sett kunne man tenke seg lignende satsinger innen områder som «skoleutvikling», klima, teknologi og entreprenørskap» m.m. I denne type satsinger kunne man tenke seg at temaene var rimelig definerte på forhånd, men der prosjektene var mer åpne i sin utforming, også i forhold til hvilke organisasjoner, hvilke utdanningsnivåer og sektorer som kunne delta.

Oppsummert vil hovedanbefalingene i forhold til dette perspektivet derfor kunne konkretiseres som følger:

- Dagens programmer bør utvikle en mye tydeligere endimensjonal profil - eksempelvis gjennom en sterkere tematisk orientering, eller et fokus på en bestemt aktivitet.

- Det bør vurderes å redusere antall program gjennom sammenslåinger.

- Dagens programperiode forlenges, eksempelvis med fem år.

- Organiseringen med hoved- og medadministratorer beholdes, men programstrukturen forenkles gjennom kun å ha en felles programkomite, men der enkeltmedlemmene har et spesielt ansvar for ulike delprogram.

- Det utnevnes en «arbeidende programleder» av en ny hovedkomite som vil ha det overordnede ansvaret for løpende utvikling og drift av programmet.

- «Arbeidende programleder» vil ha hovedansvar for Nordplus i forhold til sekretariatet i København, og vil kunne bruke hovedkoordinator som instrument for å styrke analyse, profilering og videreutvikling av Nordplus.

- Ansvaret for driften av ARS legges til hovedkoordinator.

- Det bør gjøres en målrettet satsing på dagens webportal for å aktivere denne som et mer dynamisk redskap i profileringen av Nordplus. En egen stilling som webredaktør bør vurderes. 
- Det etableres et garantifond slik at man kan tildele litt mer enn tildelte ressurser hvert år, og på denne måten ta høyde for å håndtere problemstillingen med ubrukte midler innenfor programperioden.

- NSK inkluderes som en del av rammeprogrammet, men kulturdelen tas ut og returneres til Junior.

I tillegg bør følgende mer detaljerte anbefalinger vurderes:

Horisontal:

- Horisontal slås sammen med Voksen, og med en tung profil knyttet til livslang læring og kompetanseutvikling på tvers av sektorer og organisatoriske grenser.

- Ressursrammen til programmet søkes økt, og man bør søke å profilere programmet som særegent i forhold til Høyere utdanning.

Høyere utdanning:

- Omfanget på aktivitetene innen programmet reduseres - og programmet bør spesielt fokusere på «ekspressmobilitet» som et satsingsområde.

- Fordeling av ressursene innen programmet revurderes, og man bør i enda sterkere grad vektlegge kvalitet, samt større og tyngre nettverk for derigjennom å bedre synlighet og eksternt gjennomslag.

Junior

- Konsentrere Junior om mobilitetsaktiviteten der elevene i sentrum, og der de er involvert i faglig aktivitet og får direkte erfaring med å møte jevnaldrende i andre land og samarbeide med dem.

- Flytte rene utviklingsprosjekter (der de voksne, dvs. lærere, skoler, skoleeiere etc er aktørene, og der kriteriene for tildeling av midler er resultater i form av forbedrede pedagogiske metoder etc.) til Horisontal.

- Redefinere tematisk nettverk slik at det kan ha relevans som aktivitet i tilknytning til mobilitet.

Voksen:

- Redefinere programmet og konsentrere Voksen på individene og de delene som styrker det brede feltet og de svake aktørene.

- Beholde og styrke mobilitet med tematisk innhold (jf Junior).

- Flytte dagens utviklingsprosjekter til Horisontal.

NSK:

- NSKs delprogram for mobilitetstiltak flyttes til Nordplus junior. En bestemt andel av mobilitetstiltakene øremerkes for språklig mobilitet, her stilles det krav om at fellesspråket skal være et skandinavisk språk. 


\subsection{Koordinering}

Det er imidlertid ikke bare Nordplus programmene som er i endring - også utenfor Nordplus programmene tas det mange initiativ på det nordiske plan som indikerer at tiden kanskje er moden for å se på de ulike virkemidlene og initiativene som tas i det nordiske rom mer i sammenheng. Eksemplene på til dels overlappende aktiviteter er mange og inkluderer bl a etableringen av nordiske masterprogrammer, kultursatsinger der mobilitet og erfaringsutveksling inngår, samt ulike initiativ innen forskning og utvikling herunder etableringen av, og aktiviteter innen Nordforsk.

Et argument for sterkere koordinering av de ulike virkemidlene kan hentes fra de mer generelle politiske intensjoner om tettere integrering av forsknings-, utdannings- og innovasjonsfeltet, herunder ambisjonene om utvikling av sterke «kunnskapstriangler» der gamle grenseoppganger og politikkforståelser må brytes ned, og der man heller vektlegger hvordan utvikling, innovasjon og entreprenørskap foregår i praksis.

Hvis man ønsker at Norden også skal fremstå som en region kjennetegnet av nytenkning og eksperimentering med nye initiativ og organiseringsformer kan man stille spørsmålstegn ved Nordplus som en selvstendig programsatsing, alternativt hvor lenge en slik satsing skal vare.

Som et eksempel på initiativ utenfor Nordplus, men som kunne koples sterkere til programmet er satsingen på nordiske masterprogrammer. Nordiske masterprogrammer har vært en stor suksess målt gjennom interessen for programmet, og at man gjennom etableringen av felles utdanningsprogrammer inngår mer forpliktende samarbeid enn gjennom ordinær mobilitet, utvikling av enkeltkurs, konferanser m.m. Samtidig er det altså også mulig å få støtte til utvikling av felles masterprogrammer i Nordplus Høyere utdanning, og det er mulig å stille spørsmål ved om ikke tiden kan være moden for å se ulike initiativ innen Nordisk ministerråd mer i sammenheng. Hvis Globaliseringsinitiativet skal ha den tilsiktede effekt er det ikke minst viktig å sikre at de tiltak som settes i verk ikke bare blir mer ad-hoc initiativ, men at man sikrer en organisatorisk ramme som kan sørge for kontinuitet og langsiktighet.

Hvis man også ønsker en sterkere satsing på PhD programmer bør imidlertid en slik satsing koordineres med den aktivitet som allerede foregår innenfor Nordforsk. Her synes veien frem å være noe lenger, og en slik satsing ville også dreie fokus bort fra utdanning til mer forskningsrelaterte aktiviteter.

Ønsker man å ivareta fokuset på utdanning kan imidlertid en annen vei fremover være å ta sikte på å omforme Nordplus rammeprogrammer til en egen organisatorisk satsing slik ulike forskningsinitiativ ivaretas og koordineres av Nordforsk. Her fungerer etableringen av en egen organisatorisk enhet som en viktig koordineringsmekanisme i seg selv. Å organisere aktiviteter som et «program» har sine ulemper - ikke minst knyttet til strategiutvikling, oppfølging, profilering og gjennomføringsevne, og det kan stilles 
spørsmålstegn om selv en mer profesjonalisert lederrolle i programmet (slik som det er antydet i punkt 9.1 og 9.2) vil være tilstrekkelig for å få til den målrettethet som er ønskelig.

Hvis Nordplus omformes fra «program» til «organisasjon» kunne man prinsipielt tenke seg at man på en enklere måte kan drifte initiativ så som masterprogrammer, Centres of excellence innen skole og utdanning, men også ulike nettverksinitiativ, utviklingsprosjekter, kunnskapsstatusoversikter. Her finnes det allerede flere nettverk i Norden som kunne inkluderes i en slik satsing (eksempelvis NVL). En slik omforming av Nordplus innebærer imidlertid en vilje til å se ulike aktiviteter under Nordisk ministerråd mer samlet, og der ressursrammene er slik at etableringen kan forsvares.

Oppsummert vil hovedanbefalingene i forhold til dette perspektivet derfor kunne konkretiseres som følger:

- Dagens programstruktur termineres, og Nordplus som «programsatsning» avløses av en mer permanent organisatorisk enhet under Nordisk ministerråd med et spesielt fokus på utdanning.

- Nordiske masterprogrammer bør videreføres, og vurderes som en ny og egen satsing en slik organisatorisk enhet

- Det kan videre vurderes om ikke egne «Centres of Excellence» innen skole, utdanning, og livslang læring kan etableres

- Den nye organisatoriske enheten burde også være langt mer operativ i forhold til å være iverksettere av politikk i forhold til å utarbeide kunnskapsoversikter, kartlegge initiativ og analysere «best practise» i forhold til skole og utdanning i de nordiske land.

\subsection{Etterord}

De tre scenariene som er skissert over er selvfølgelig ikke de eneste mulige utviklingsveiene for Nordplus i årene som kommer. Kombinasjoner av elementer i de ulike scenariene er selvfølgelig også mulig - ett eksempel kan her være integreringen av de nordiske masterprogrammer - og de tre scenariene kan ikke minst oppfattes som stadier i en mer langsiktig utviklingsprosess for Nordplusamarbeidet.

Scenariene er slik de er beskrevet her også mer å oppfatte som skisser, enn som fasttømrede forslag, og det finnes helt sikkert gode forslag og ideer som ikke er nevnt foran som kan ha betydning for de beslutninger som skal fattes. Poenget med scenariene har imidlertid vært å utfordre den «naturlige» utvikling og tenkning som har preget Nordplus i det siste tiåret, og stimulere til debatt og kritisk refleksjon rundt et samarbeid som på mange måter har vært en stor suksess for det nordiske samarbeidet. Slik sett er det grunnleggende spørsmålet om man skal endre på en formel som har vist seg bærekraftig over lang tid, eller om det er nettopp endring og utvikling av formelen som skaper den langsiktige bærekraft. 



\section{Litteratur}

CIMO (2009) Årsrapport 2009. Helsinki: CIMO.

CIMO (2010) Nordplus självutvärdering. Helsinki: CIMO.

CIMO (2010) Applications and proposal for distribution of funds 2010. Helsinki: CIMO.

Det internationale kontor for uddannelse (2010) Selvevaluering - Nordiske språk og kultur. Reykjavik: Det internationale kontor for uddannelse.

Internationella Programkontoret (2010)

Nordplus selvevaluering. Stockholm: Internationella programkontoret.

Janson, K., Schomburg, H. \& Teichler, U. (2009) The professional value of Erasmus mobility. ACA Papers on International Cooperation in Education. Bonn. Lemmens.

Nordisk Råd (2006) Ministerrådsforslag om videreutvikling av Nordplusprogrammene for 2008-2011. København: Nordisk Råd.

Nordplus Framework Programme (2008-2011). Handbook 2010.
Nordplus Common Programme Document (2008-2011).

SIU (2009) Brief note on the status of the Nordplus Framework programme. SIU. Bergen.

SIU (2010a) Selvevaluering - Horisontal. Bergen: SIU.

SIU (2010b) Selvevaluering - Hovedkoordinator. Bergen: SIU.

SIU (2010c) Intern undersøkelse om fordeling av programmidler i Nordplus. Bergen: SIU.

Styrelsen for International Uddannelse (2010) Selvevaluering. København: Styrelsen for International Uddannelse

Vabø, A. (2006) Nordplus - kontinuitet og endring i programvirksomheten. En evaluering. NIFU. (Upublisert notat). Oslo. Yrkesakademin i Österbotten (2009) Kultur i vården för den nordiska äldreomsorgen. Rapport om Nordplus Vuxen utvecklingsprojekt. Yrkesakademin i Österbotten: Rapport nr 1 YA! 

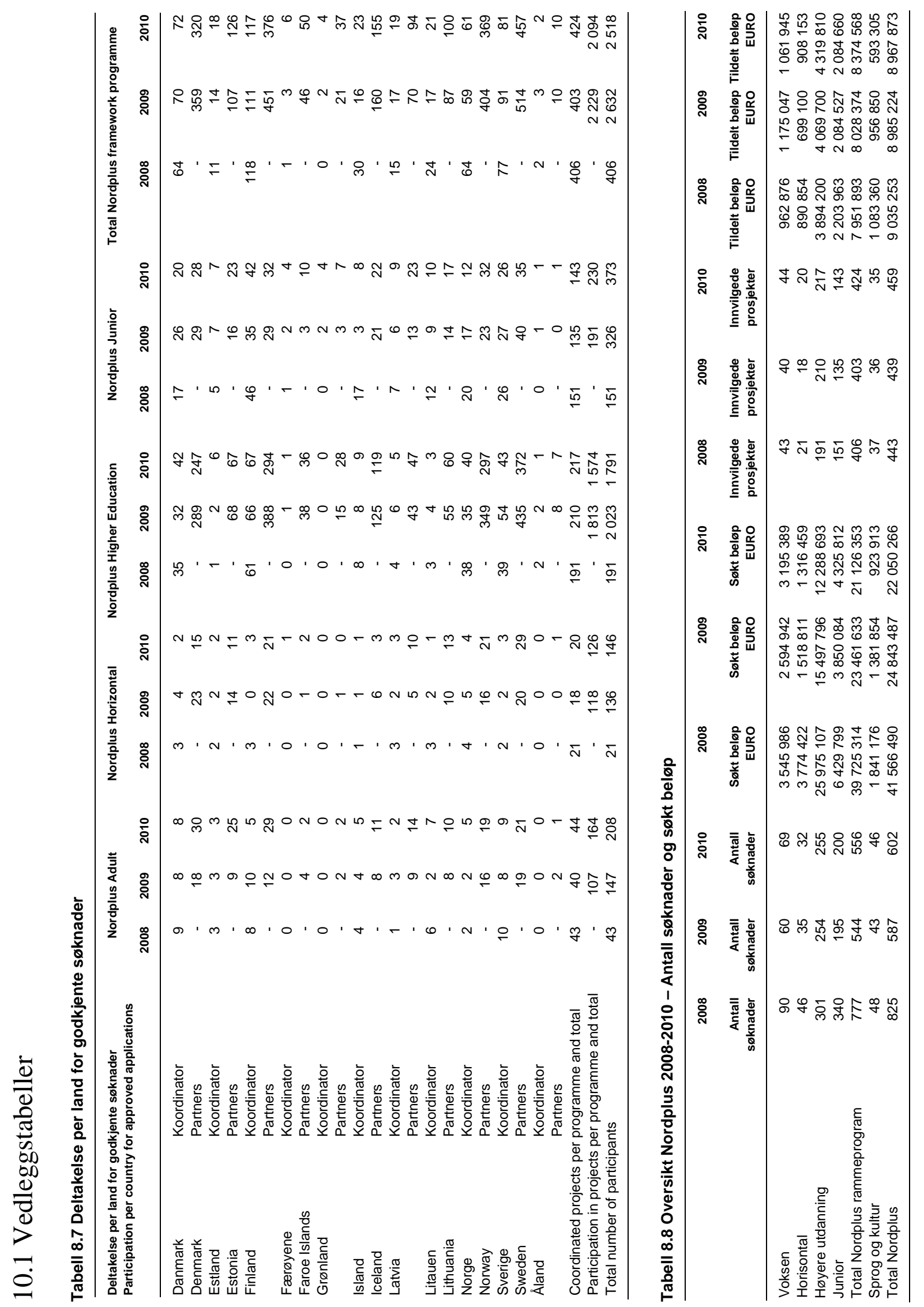